\title{
14. CHERTS AND PORCELLANITES FROM THE NORTH PACIFIC, DSDP LEG 32
}

\author{
J. B. Keene, Geological Research Division, Scripps Institution of Oceanography, \\ University of California, La Jolla, California
}

\begin{abstract}
Ten sites were drilled on Leg 32 and seven sampled chert and porcellanite of Cretaceous age. Only Site 313 had Cenozoic (Eocene) chert. The lack of Eocene chert is explained by the sites being north of the high-productivity equatorial zone at that time. Sites 305,306 , 310 , and 313 contain nodular and bedded chert and porcellanite associated mainly with carbonate. Sites 303, 304, and 307 contain mainly bedded cherts associated with pelagic clay; minor carbonate occurs with chert immediately above basement. The porcellanites with carbonate contain initially both opal-CT and quartz as the silica phase. The conversion of opal-CT to quartz is complete in younger rocks where it is associated with carbonate rather than clays. More quartz is precipitated directly if the ratio of foraminifera to nannofossils is high in the sediment being replaced. The presence of clay in a microenvironment favors precipitation of opal-CT. Porcellanites associated with noncarbonate sediments are mainly composed of opal-CT. Sites 303 and 304 have the oldest opal-CT: Hauterivian to Valanginian age ( 118 to 130 m.y.).

Biogenous opal is the silica source for most cherts. Composition and texture of the host sediment determines where chert will form. Bedded calcareous porcellanites may take 40 to $50 \mathrm{~m}$.y. to form, but chert nodules seem to form earlier. Some chert of Barremian to Hauterivian age associated with volcanic glass, clinoptilolite, and montmorillonite may have a volcanic origin.
\end{abstract}

\section{INTRODUCTION}

Samples of chert and porcellanite were recovered during Leg 32 from seven drilling sites in the North Pacific Ocean; three sites contained no chert. Figure 1 is a map of the North Pacific showing the location of the drill sites and the major bathymetric features of the area. The detailed stratigraphy, the distribution of porcellanite, chert, siliceous fossils, and the amount of core recovered are presented in Figures $2 \mathrm{a}$ and $2 \mathrm{~b}$. Cherts and porcellanites occur in the Cretaceous section from all seven sites, however, the only Cenozoic samples recovered are in sediment of Eocene age and occur at Site 313 . The plates provide a brief description of a selection of the many siliceous rocks recovered during Leg 32. Previous studies on chert from this general area have been made by Heath and Moberly (1971) and Lancelot (1973).

A review of previous DSDP reports shows that chert, both nodular and bedded, is common in sediment of middle Eocene and older age and has been found in the Atlantic, Pacific, Indian, and Southern oceans. The chert is associated with a variety of sediments but most frequently with carbonate, and siliceous oozes and clays.

The aim of this study is to describe the variety of siliceous rocks sampled and their bearing on the questions of: source of the silica, time of formation, site of formation, and silica mineralogy. Emphasis is placed on the mineralogy of porcellanites, and particularly on the ratio of quartz to carbonate and opal-CT.

\section{METHODS AND TERMINOLOGY}

Study of thin sections was supplemented by X-ray diffraction analysis of crushed ( $<200$ mesh) bulk samples of porcellanite and chert, following the method based on peak heights and intensity factors described by Cook et al. (in press) for DSDP samples. Results were compared with standard mixtures of quartz, calcite, and opal-CT and found to agree within $\pm 5 \%$. Additional X-ray data were taken directly from Zemmels and Cook (this volume).

Fracture surfaces of selected samples were coated with $\mathrm{Au}$ and $\mathrm{Pd}$ and examined with a Cambridge scanning electron microscope (SEM) for textural information. An energy disperser X-ray analyzer (Ortec) was used on carbon-coated samples for element analysis and element maps. Cathodoluminescence was observed with an electron microprobe on carbon-coated polished sections.

Radiographs were made of 2-mm slices of rock using an X-ray source ( $90 \mathrm{kv}$ and $10 \mathrm{ma}$ ) at a distance of 75 $\mathrm{cm}$. The samples were exposed for 1 to $3 \mathrm{sec}$ on Kodak industrial X-ray film (Type $M$ ).

The interstitial water was squeezed from sediments at $4^{\circ} \mathrm{C}$ and the dissolved silica was measured using the method of Mullin and Riley (1955) as adapted by Mann and Gieskes (in press); carbonate contents of crushed samples were determined by the "Karbonat-Bombe" described by Müller and Gastner (1971).

Wet bulk densities were determined with a Jolly balance after $24 \mathrm{hr}$ saturation in distilled water under a 


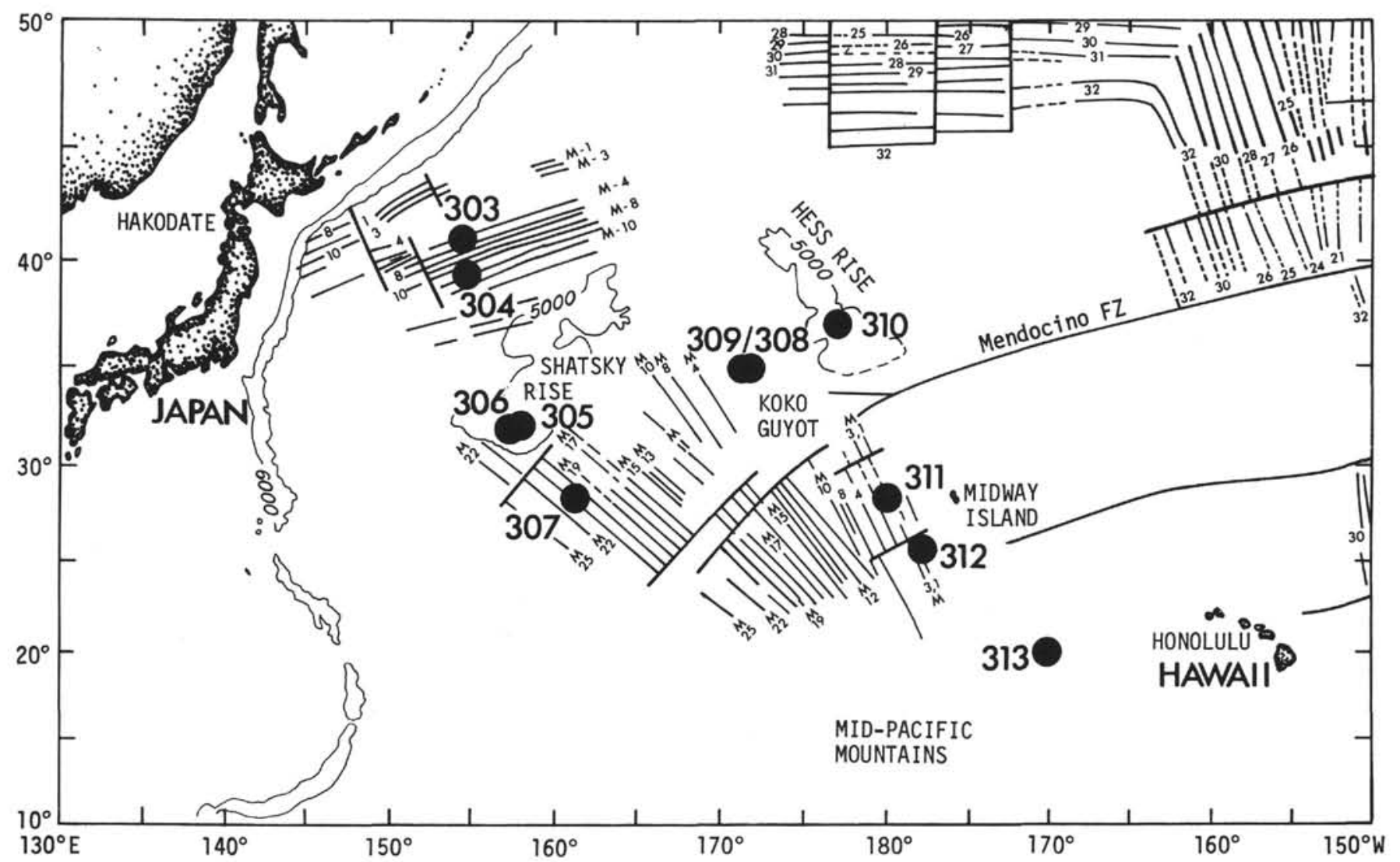

Figure 1. Location of Leg 32 drill sites. Magnetic lineations are also shown (after Larson and Chase, 1972).

partial vacuum. Grain densities were measured with a pycnometer using wetted specimens and from these measurements apparent porosity was calculated.

Sample identification consists of three symbols referring to drill site, core number, and section number or core catcher, respectively.

Nonclastic $a$-quartz, found in the siliceous rocks, was subdivided into: (1) chalcedony: cryptocrystalline, optically fibrous. (2) microquartz: anhedral, interlocking grains $<20 \mu \mathrm{m}$. (3) megaquartz: grains $>20 \mu \mathrm{m}$. Includes drusy quartz.

The opal classification follows Jones and Segnit (1971):

Opal-A: X-ray amorphous. Broad low diffractogram peak at $22^{\circ} 2 \theta \mathrm{Cu}(4.0 \mathrm{~A})$.

Opal-CT: Disordered $\alpha$-cristobalite, $\alpha$-tridymite. Broad X-ray diffraction peaks at $20.5^{\circ}, 21.5^{\circ}$, and $38.8^{\circ}$ $2 \theta \mathrm{Cu}$ corresponding to $4.3,4.1$, and $2.5 \AA d$-spacings.

Well-ordered $\alpha$-cristobalite (opal-C) has not been found in deep-sea chert, porcellanite, or biogenic siliceous sediment.

Names for the semilithified to lithified deep-sea samples referred to in this report are based on handspecimen characteristics and follow the definitions in the Glossary of Geology (AGI, 1972). The names are not based on the nature of the silica phase. They are:

Chert: A hard, compact, cryptocrystalline, varicolored sedimentary rock with semivitreous luster and consisting dominantly of silica. It has a splintery to conchoidal fracture and may contain minor amounts of other minerals.
Porcellanite: A siliceous rock that is less hard and less compact than chert. It has a dull luster and adheres to the tongue when licked. It usually consists of either opal and quartz or quartz together with clays, carbonate, zeolites, or iron and manganese minerals. It includes what otherwise may be called siliceous limestone or siliceous claystone/siltstone/mudstone.

\section{DESCRIPTIONS OF CHERTS \\ AT INDIVIDUAL SITES}

The sites can be divided into two distinct groups and will be discussed separately. The division is based on the dominant lithofacies, either carbonate or clay, associated with the chert. The presence of carbonate or clay reflects biological productivity and water depth.

Group 1: Sites above 4000 meters depth include 305 $(2903 \mathrm{~m}), 306(3399 \mathrm{~m}), 310(3516 \mathrm{~m})$, and $313(3484 \mathrm{~m})$ (Figure 2a). These sites have been above the calcite compensation depth (CCD) for most of their history, resulting in carbonate sediments dominating the lithology. The silica distribution varies with depth, age, and between sites, depending on the paleogeographic location of the site with respect to the high-productivity zones for siliceous fossils near the equator and in high latitudes.

Group 2: Sites below 5000 meters depth include 303 $(5609 \mathrm{~m}), 304(5630 \mathrm{~m})$, and $307(5696 \mathrm{~m})$ (Figure 2b). Basement at each of these sites is overlain by a carbonate and chert sequence which in turn is overlain by chert and pelagic clay. The carbonate was deposited when the basement was above the CCD at the ridge 

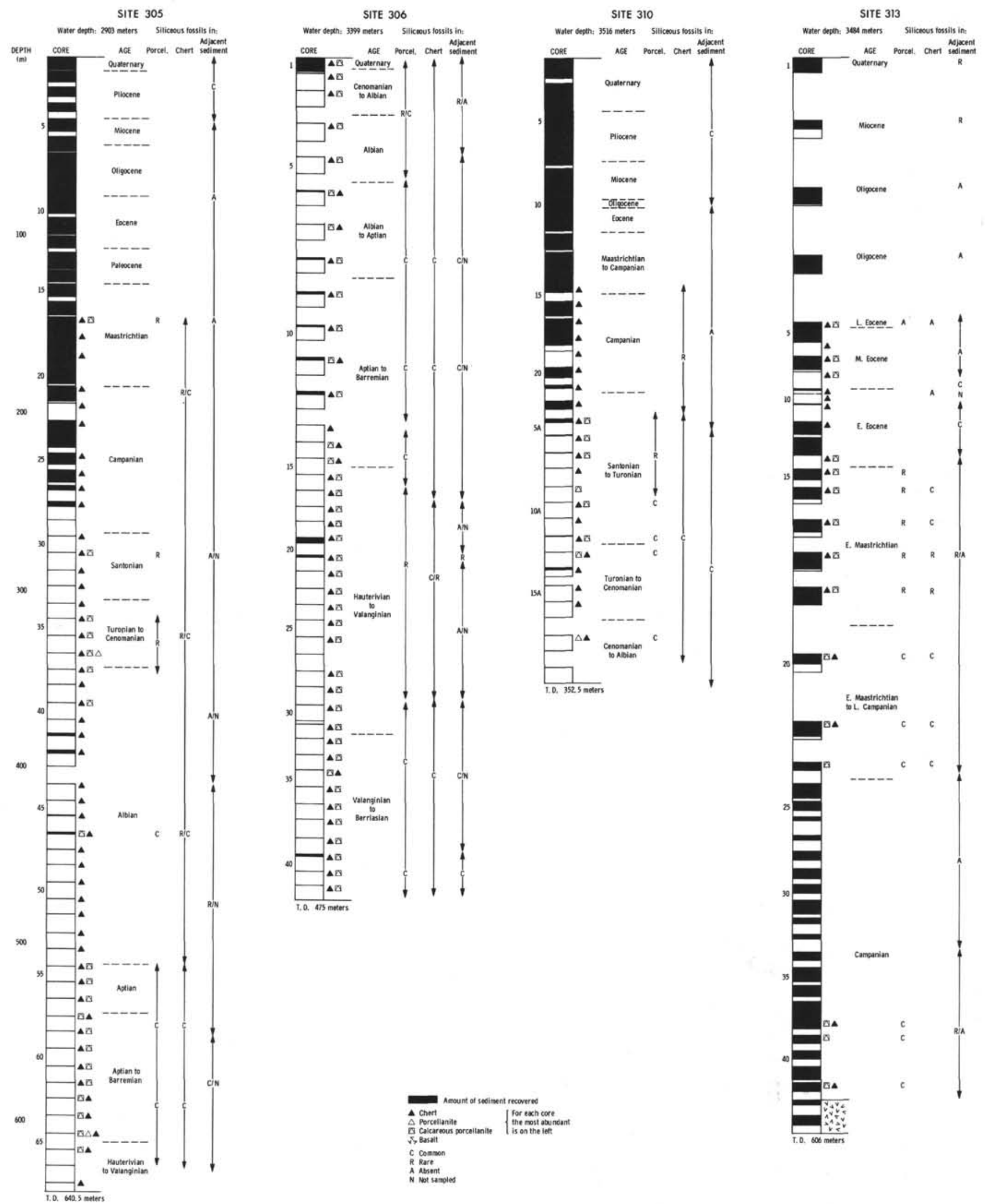

Figure 2a. Stratigraphic column for Sites 305, 306, 310, and 313 showing the distribution of chert, porcellanite, and siliceous fossils. 
SITE 303

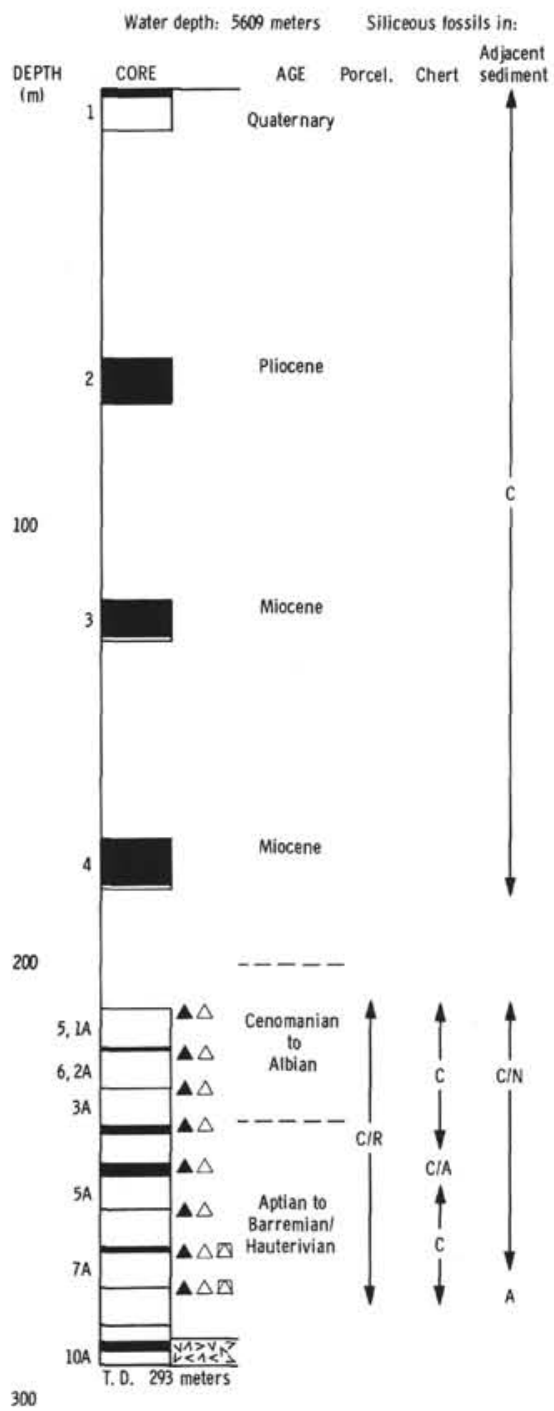

SITE 304

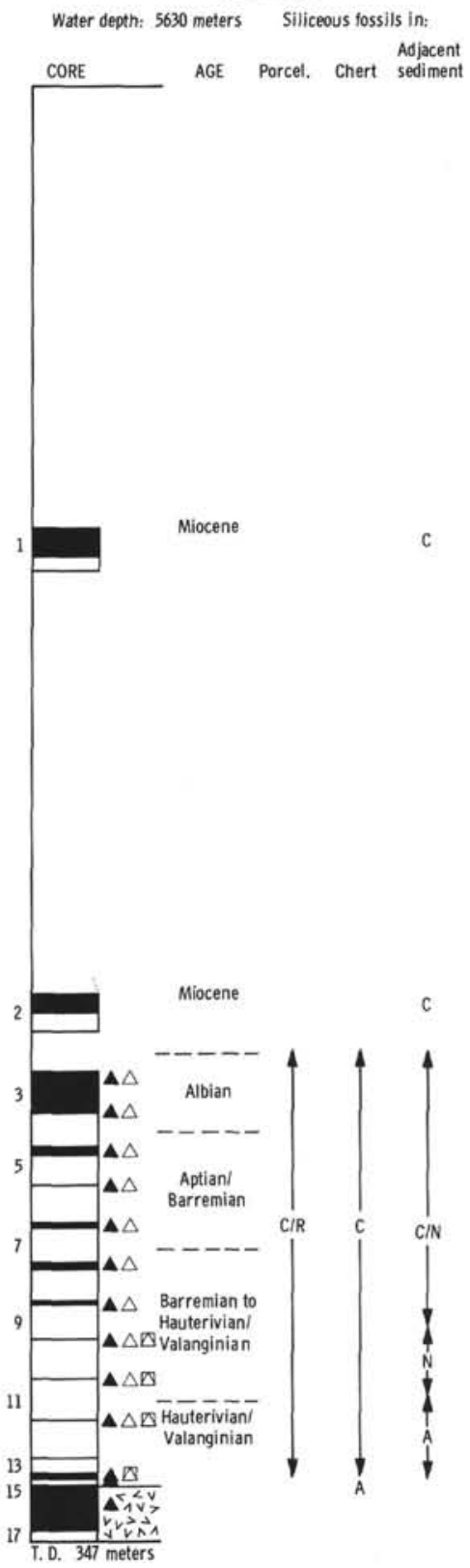

SITE 307

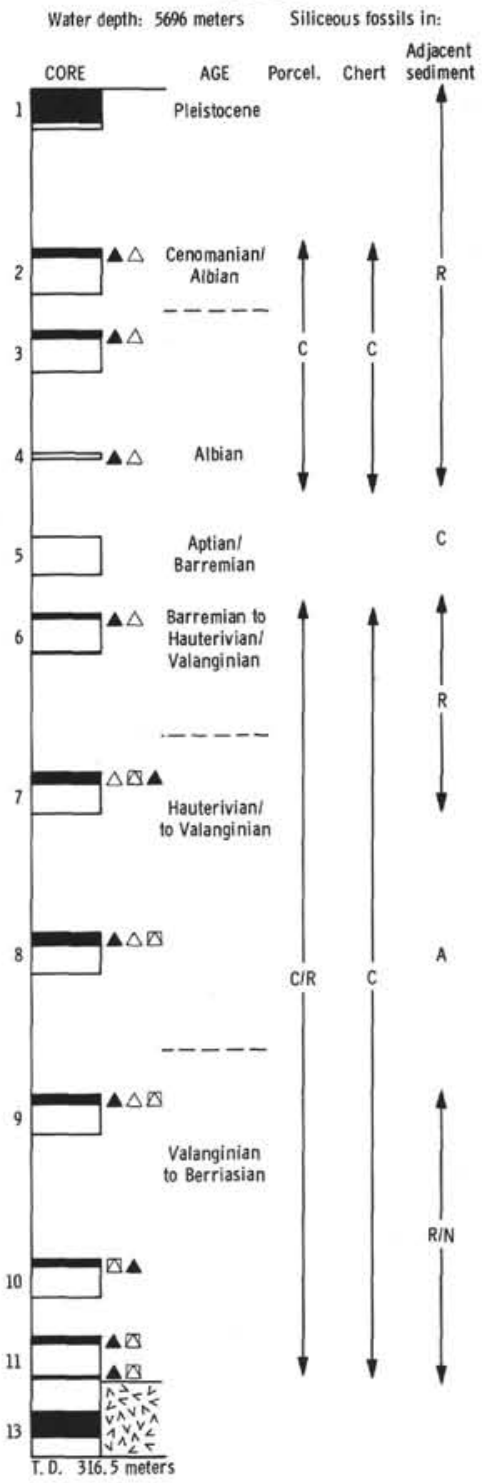

Figure 2b. Stratigraphic column for Sites 303, 304, and 307 showing the distribution of chert, porcellanite, and siliceous fossils. (See Figure 2 a for key).

crest. With subsidence the sediment surface moved below the CCD and pelagic clay and biogenous silica were deposited.

\section{Group 1}

\section{Site 305, Shatsky Rise}

Pelagic carbonate sediments dominate the section, the only noncalcareous lithologies other than chert occur in Cores 37, 64, and 65. The first chert was encountered in Core 17 at a depth of 153 meters within sediments of middle Maestrichtian age, 24 meters below the Mesozoic-Cenozoic boundary. The hole terminated at 640.5 meters in chert and sediment of Hauterivian to Valanginian age. In the Cenozoic section radiolarian tests, diatom frustules, silicoflagellates, and sponge spicules are common down to and including part of Core 5, which is late Miocene age. Below this core the Cenozoic is devoid of siliceous fossils and contains no chert.

The depth of fourteen chert samples and the nature of their silica phase are plotted on Figure 3a. Thirteen of the cherts contain more than $95 \%$ quartz as the crystalline phase. One chert from Core 37 , associated with a carbonaceous shale, contains $10 \%$ opal-CT in addition to quartz. Figure $3 \mathrm{a}$ also shows plots of fourteen porcellanites, twelve of which are calcareous. Their carbonate content is shown in Figure $3 \mathrm{~b}$.

Down to Core $47(438 \mathrm{~m})$ porcellanite is a minor rock type, occurring only as inclusions in and a coating on the chert nodules and fragments (Plate 1). The cal- 


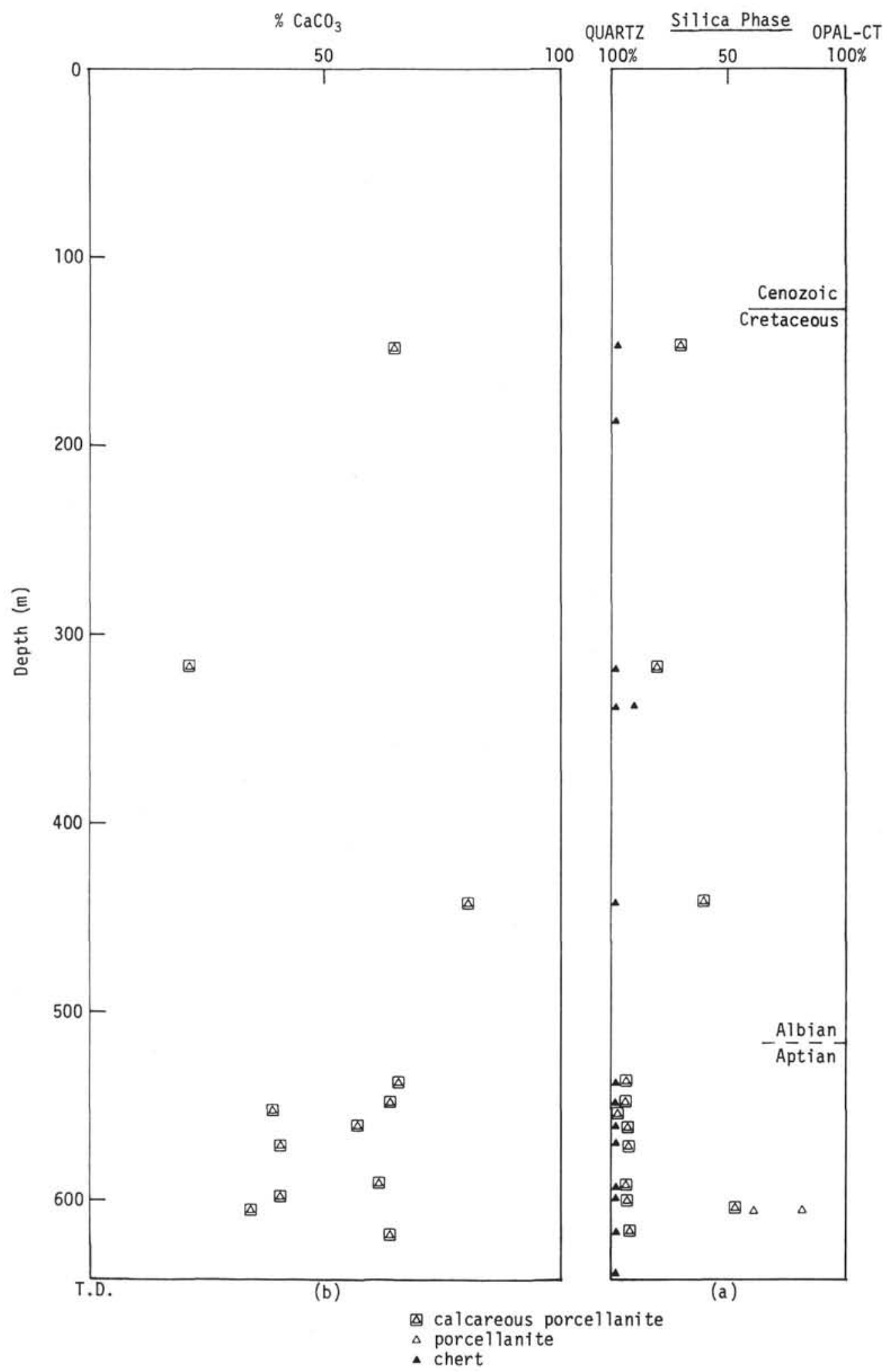

Figure 3. (a) Silica phase present in chert and porcellanite from Site 305. (b) Carbonate content of porcellanite from Site 305. 
careous porcellanite in this interval is adjacent to sediment with greater than $97 \% \mathrm{CaCO}_{3}$ (Bode, carbonate analysis, this volume) and noncalcareous chert. In Core 47 , and particularly below Core 56, recovery of porcellanite increased and sometimes dominated over chert. For example, Plate 3 shows samples of massive radiolarian-rich calcareous porcellanite from Cores 58 and 63 .

Below 500 meters the calcareous porcellanite contains only quartz as the silica phase. The sole exception is Sample $305-65-1$ which contains $52 \%$ opal-CT. This sample is associated with a shaly layer and a noncalcareous porcellanite which contains $60 \%$ to $80 \%$ opalCT and fossils of early Aptian or Barremian age (Plate 4). A common feature of the noncalcareous layers of Cores 37,64 , and 65 is their high organic content. A shale from Core 64 contained $9.3 \%$ organic carbon. This high organic content is reflected in the gray (N5), brownish-gray (5YR4/1), and black (N2) color of the associated chert. In addition, cherts from these stratigraphic levels contain pyrite either within the rock or as euhedral crystals up to $5 \mathrm{~mm}$ in size lining voids (Plate 1, Figure 7).

\section{Site 306, Shatsky Rise}

Site 306 is located only $37 \mathrm{~km}$ away from Site 305 and in slightly deeper water. The youngest cherts occur in Core 1 at a depth of 8 meters in sediment of late Albian age. Chert was present in all cores retrieved from the hole. The site terminated in chert and calcareous sediments of early Berriasian age at a depth of 475 meters. The only noncalcareous sediment recovered is a carbonaceous shale in Cores 12 and 13 of Aptian to Barremian age, correlating with a similar lithology from Core 305-64.

Calcareous porcellanite is a minor lithology down to Core 6, and occurs as a coating on, and inclusions in, chert nodules. In Cores 6 through 16 (75.5 to $244 \mathrm{~m}$ ), massive radiolarian-rich calcareous porcellanite is common, correlating with that in 305 , (Plates 5 and 6). From Core 16 to Core 29 (244 to $336 \mathrm{~m}$ ), there is generally less porcellanite and more nodular chert in a radiolarianpoor nannofossil chalk. Below Core 29, calcareous porcellanite again becomes common and radiolarians are present.

$\mathrm{X}$-ray results of twelve cherts from this site show the cherts to be quartzose (Figure 4). Six calcareous porcellanites contain quartz as the sole silica phase and six contain opal-CT and quartz. The opal-CT porcellanites are restricted to the upper 200 meters of the hole and all the quartzose porcellanites are deeper.

\section{Site 310, Hess Rise}

The dominant nonsiliceous lithology recovered at Site 310 was pelagic carbonate with minor zeolitic pelagic clay in Cores 10 and 11 (89 to $99.5 \mathrm{~m}$ ) and carbonaceous shale in Core 17A $(325 \mathrm{~m})$. The first chert occurs in Core 15 at a depth of 128 meters in sediment of late Campanian age, 29 meters below the MesozoicCenozoic boundary.

As at Site 305, the Cenozoic section at Site 310 contains no chert. However, it does contain diatoms and silicoflagellates down to the base of Core $8(71.5 \mathrm{~m}$, late Miocene). Radiolarians are common down to Core 10 (early Oligocene), but are absent from the middle and lower Eocene, Maestrichtian and upper Campanian and they do not reappear in the calcareous sediment above Core $8 \mathrm{~A}$ (231.5 m, Santonian). Radiolarians are present from 231.5 meters down to the base of the hole at 352.5 meters in Cenomanian sediment.

Calcareous porcellanite, with $40 \%$ to $50 \% \mathrm{CaCO}_{3}$, is common in Cores $10 \mathrm{~A}, 12 \mathrm{~A}$, and 13A, but elsewhere exists only as thin coatings or inclusions in chert (Plates 8 and 10). Noncalcareous porcellanite is found near the base of the hole in Core 17A.

Of the five cherts X-rayed, the four associated with carbonate are entirely quartz, whereas the remaining one, from noncalcareous sediment in Core 17A, contains $15 \%$ opal-CT. The three porcellanites analyzed contain more opal-CT than quartz (Figure 5). The most opal-CT is in the noncalcareous basal porcellanite.

\section{Site 313, Mid-Pacific Mountains}

Site 313 , situated in a shallow basin in the northeast Mid-Pacific Mountains, provided the only Cenozoic chert recovered during Leg 32. Chert was first encountered in Core $5(150 \mathrm{~m})$ with pelagic calcareous sediment and turbidites of late Eocene age. Chert continued to be found in the middle and lower Eocene and immediately below the Mesozoic-Cenozoic boundary at 232.5 meters, continuing down to Core $23(400 \mathrm{~m})$, in middle and lower Maestrichtian calcareous sediments.

Cores 20,21, and 22 contain fragments of porcellanite which are rare in the younger cores. A sequence of calcareous volcanic sediment which lacks chert occurs between Cores 22 and 38 (400 to $542 \mathrm{~m}$ ). Below this sequence, in Cores 38 and 42 , calcareous porcellanite and chert are present in marly limestone of early Campanian age, (Plate 12).

$\mathrm{X}$-ray analyses of fifteen chert samples show only four to be quartzose (Figure 6a). The Cenozoic cherts and those near the volcanic sediments contain opal-CT as well as quartz. All thirteen calcareous porcellanites analyzed contain opal-CT. Those from Cores 5, 7, 22, and 42 have more than $95 \%$ opal-CT as the silica phase. Figure $6 \mathrm{~b}$ gives the corresponding carbonate content for the porcellanites.

Radiolarians are present, but rare, in the Cenozoic calcareous sediment of Cores 1 and 2; they are absent from Cores 3 to 8; and abundant in Cores 9, 12, and 13. In the Cretaceous sediment (Cores 15 to 42 ) radiolarians are common in all massive porcellanite sampled (Cores $20,21,22,38$, and 42) and rare in the other cores.

\section{Group 2}

\section{Site 303}

Chert first occurs in Cores 5 and $1 \mathrm{~A}(211 \mathrm{~m})$ in a pelagic clay of Cenomanian to late Albian age. This is the first core containing Cretaceous sediment. Diatom and radiolarian clayey ooze occurs down to middle Miocene $(183 \mathrm{~m})$, but no chert or porcellanite occur. Radiolarians are present in all the Cretaceous cores, both in the small amount of sediment recovered and in the porcellanite and chert. 


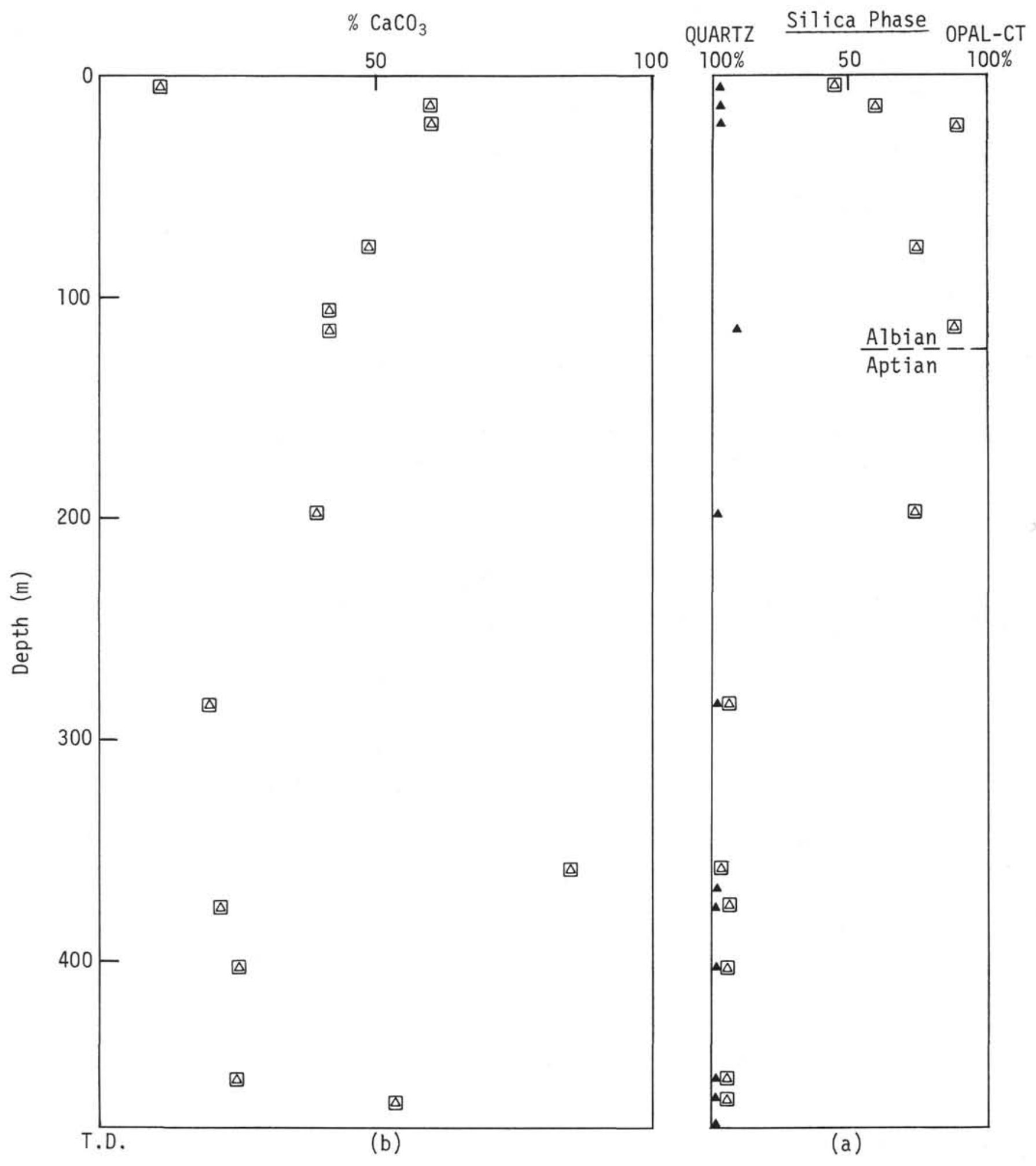

Figure 4. (a) Silica phase present in chert and porcellanite from Site 306. (b) Carbonate content of porcellanite from Site 306.

The chert recovered directly above basaltic basement (Cores $7 \mathrm{~A}$ and $8 \mathrm{~A}$ ) is associated with the only carbonate sediment sampled in this hole. Six chert samples were Xrayed and found to be quartzose (Figure 7), whereas eight porcellanites above the carbonate contain $45 \%$ to
95\% opal-CT. Porcellanite is common in Cores 1A to $6 \mathrm{~A}$, but in $7 \mathrm{~A}$ and $8 \mathrm{~A}$ only small amounts of quartzose porcellanite occur as coatings on chert. The cherts immediately above basement are in sediment of Hauterivian to Valanginian age and at a depth of 285 meters. 


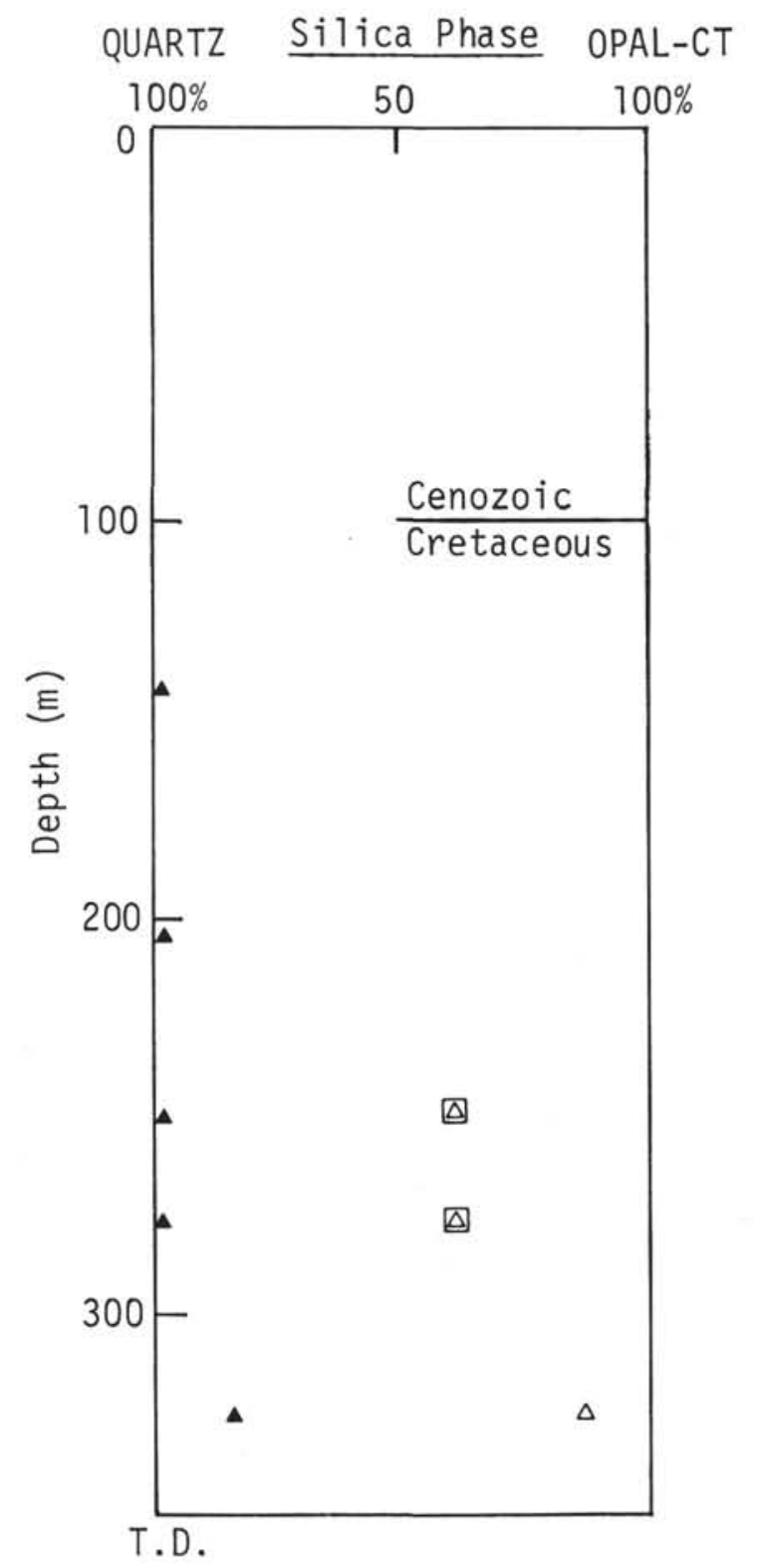

Figure 5. Silica phase present in chert and porcellanite from Site 310 .

\section{Site 304}

Chert was first recovered in Core 3 at 244 meters associated with pelagic clay. This was also the first Cretaceous (Albian) core retrieved. The two cores of late Miocene age in the overlying Cenozoic sequence contain radiolarian-diatom ooze and pelagic clay but no chert or porcellanite.

Chert occurs in all cores from 244 meters down to basaltic basement at 335 meters; the oldest is Hauterivian to Valanginian. Noncalcareous porcellanite is common down to and including Core $9(299.5 \mathrm{~m})$. In Core 10 the first carbonate occurs as a vein in chert and is present in minor amounts as nannofossil ooze in all cores down to basement. There is less porcellanite in the carbonate section.

Figure 8 gives $\mathrm{X}$-ray data for twelve porcellanites and eight cherts. The porcellanites in the noncarbonate section contain $\geq 50 \%$ opal-CT, and those in the carbonate section contain little or no opal-CT, whether or not they are calcareous. The only analyzed sample that contains opal-CT in the carbonate section is a noncalcareous porcellanite from Core 11, Section 1 with approximately $5 \%$ opal-CT. The silica phase in the cherts is quartz.

\section{Site 307}

The first porcellanite and chert recovered from Site 307 were from Core 2 at 37.5 meters in lower Cenomanian to upper Albian pelagic clay (Plate 27), but the drilling rate indicated the first chert to be at 33 meters. The only Cenozoic sediment recovered was a Quaternary surface core of zeolitic pelagic clay. Chert and porcellanite are present in all but Core 5, down to basaltic basement at 299 meters (Valanginian to Berriasian age). Core 5 consists of gray volcanic silt.

Radiolarians occur in porcellanites, cherts, and associated sediments in all the Cretaceous cores, but are rare in the sediment below 195 meters (Core 8).

$\mathrm{X}$-ray data presented in Figure 9 for six cherts show the silica phase in Cores 2, 3, and 4 to be $75 \%$ to $82 \%$ opal-CT, while in Cores 9,10 , and 11 it is quartz. Calcareous sediment was first recovered from Core 7 (158 $\mathrm{m}$ : Hauterivian to Valanginian age) and the calcareous porcellanite from this core and Cores 9 and 11 is quartzose with $13 \%, 26 \%$, and $80 \%$ carbonate, respectively. The porcellanite above Core 7 is rich in opal-CT and is associated with pelagic clay.

\section{MACROSCOPIC TEXTURE}

Despite some exceptions the following generalizations are useful in understanding the variety of chert occurring at the locations drilled.

\section{Bedding and Nodules}

Most cherts and porcellanites from Sites 303, 304, and 307 , including those associated with carbonate, have internal bedding that is either obvious or visible under the binocular microscope. This characteristic is found despite the fact that most samples are less than $6 \mathrm{~cm}$ thick. For example, Plates 18 and 27 show bedded porcellanite of alternating light and dark layers and a similar sequence within chert. Bedding is often on two scales, with thin (1 to $2 \mathrm{~mm}$ ) sometimes lenticular laminae grouped, on the basis of color, into larger units of 1 to $5 \mathrm{~cm}$.

The contacts between porcellanite and chert in samples from Sites 303, 304, and 307 are usually flat and parallel to bedding. The exceptions are the porcellanite inclusions (Plate 18) and a chert nodule within massive gray porcellanite shown in Plate 24, Figure 3. This nodule contains bedding which continues into the porcellanite. It seems likely that the bedded porcellanites and cherts from these sites are quite extensive laterally.

Among the cherts from Sites 305, 306, 310, and 313, obvious nodules occur in the carbonate ooze of the upper parts of the holes and less commonly in the porcellanites. The outline of a chert nodule is largely controlled by the presence or absence of bedding in the host sediment. For example, where the sediment is homogeneous or has been well burrowed, the chert nodules have an irregular outline (Plate 11, Figure 4), 


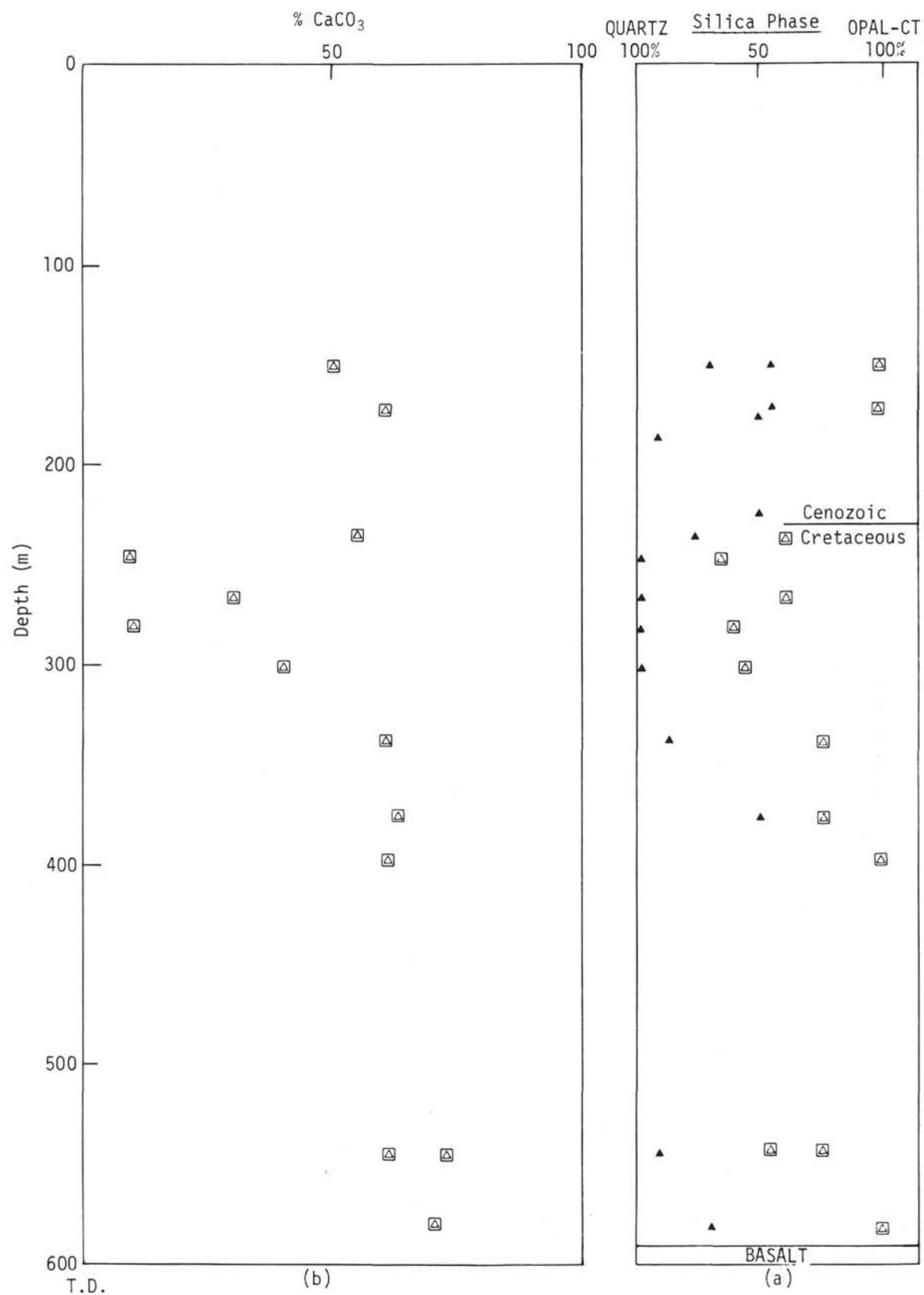

Figure 6. (a) Silica phase present in chert and porcellanite from Site 313. (b) Carbonate content of porcellanite from Site 313. 


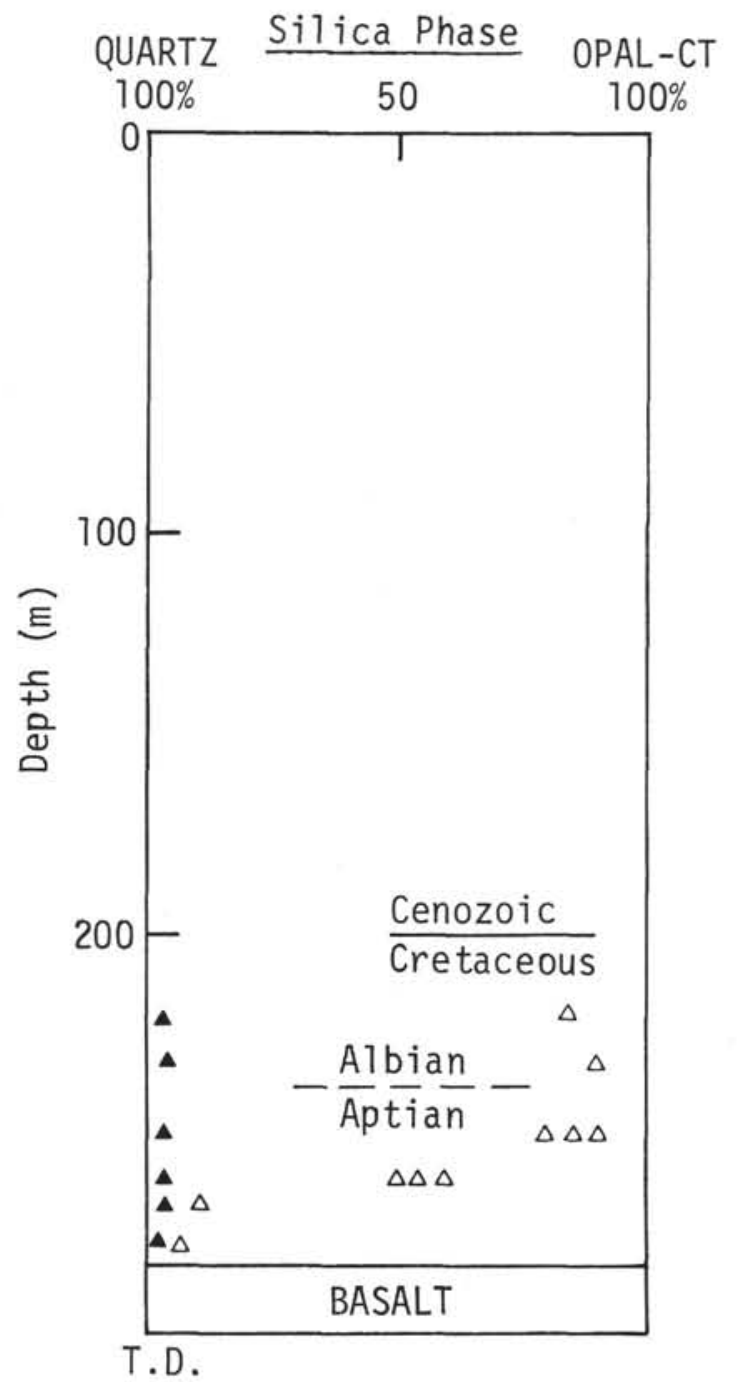

Figure 7. Silica phase present in chert and porcellanite from Site 303.

and the burrows may be preserved in the chert. In undisturbed, bedded sediments the nodules have a smoother ellipsoidal outline (Plate 3, Figure 3). Bedding is common in the calcareous porcellanites, generally as laminae and thin beds up to $1 \mathrm{~cm}$ thick (Plates 3 and 6). Silicification in porcellanite preferentially follows certain beds (Plate 12, Figure 7). Seismic reflection data suggest these calcareous porcellanites extend over the entire area of Shatsky and Hess rises.

Radiographs were taken of several chert and porcellanite slices as an aid in determining textural features. Using this technique, bedding, previously ill defined, is enhanced and sometimes is exposed in a visually homogeneous sample. Plates 3 and 10 show Xray radiographs of cherts and porcellanites with more textural details than can be seen visually. Calcareous porcellanite samples from 307-7-1, 305-58, CC, and 30635 , CC (Plates 3 and 28) contain structures which resemble ripple marks. In the horizontal dimension the structures form irregular basins or saucers with sharp crests rather than linear patterns. Alternatively, these structures could be some type of fracturing. A radiograph of Sample $305-58$, CC shows a similar pattern of ripple

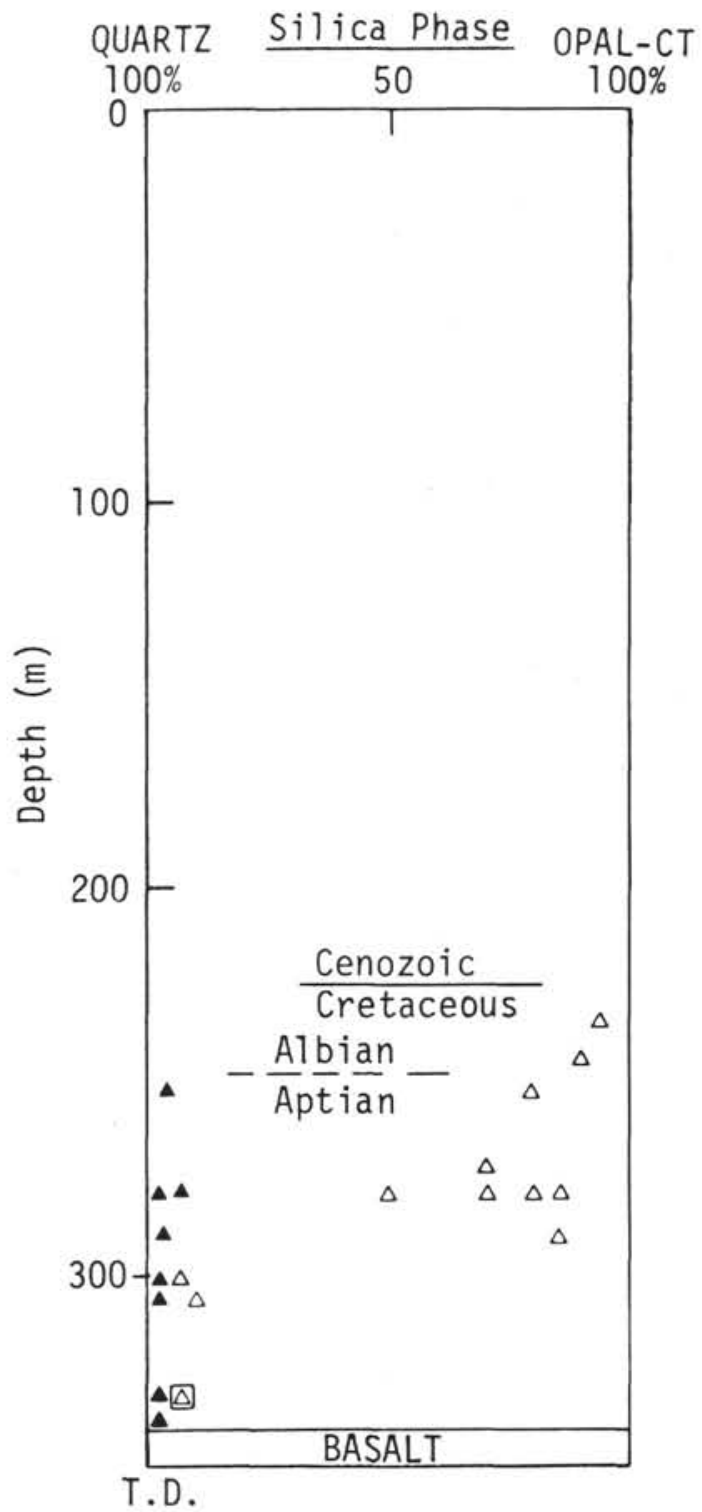

Figure 8. Silica phase present in chert and porcellanite from Site 304.

bedding in the adjacent visually homogeneous, gray porcellanite. It appears that a preferential silicification along the base of beds where porosity and permeability are greater would result in the pattern observed. Radiographs of 307-7-1 and 305-58, CC both show the increased silicification at the base of each structure but no internal bedding.

Porcellanite inclusions are also a common feature of cherts from both carbonate and noncarbonate facies. The bedded cherts shown in Plates 18 and 27 have bedding which is continued into inclusions. The inclusions form where the growth of the chert encloses the area and cuts off the supply of silica, trapping the partly silicified original minerals. A slight porosity difference may have initially retarded silica precipitation or replacement at this site.

Bedding, which was previously present in some older cherts, may have been destroyed during recrystallization 


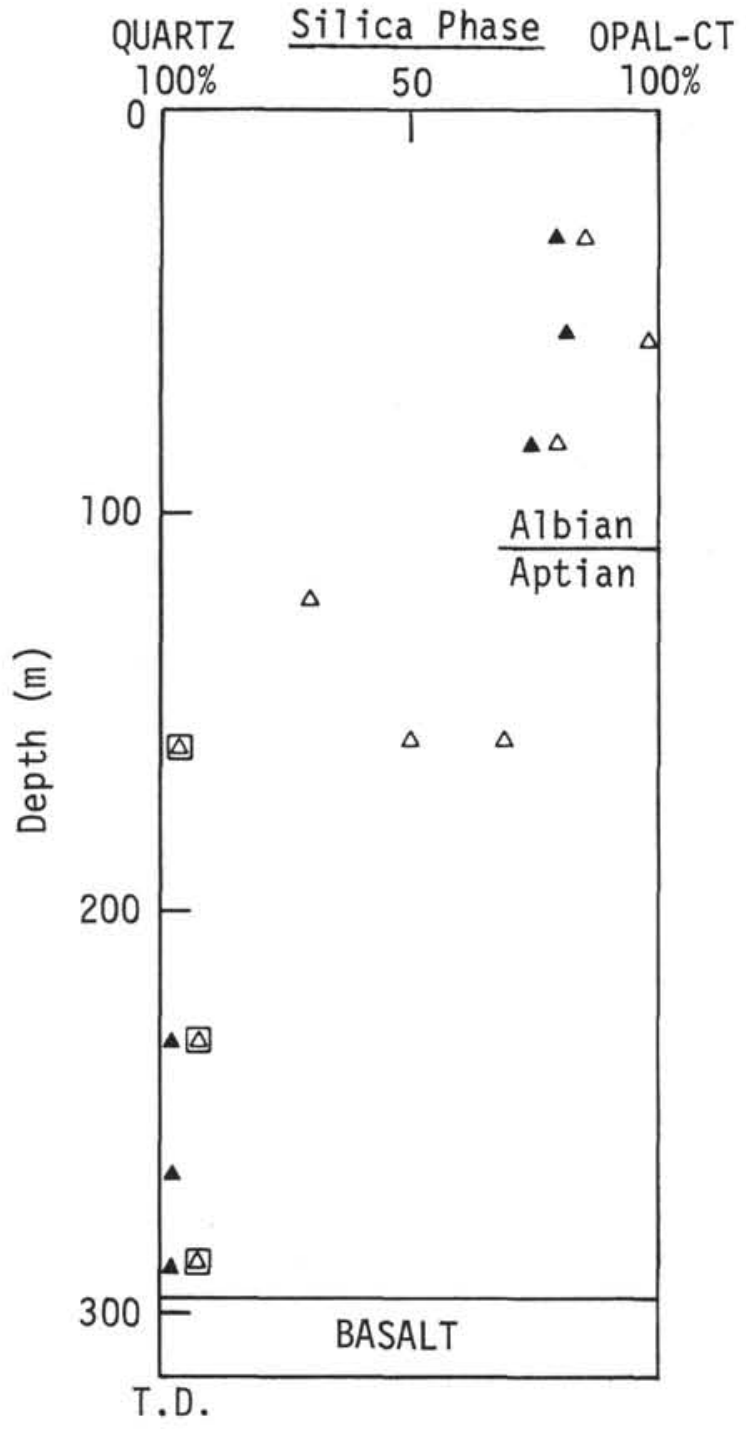

Figure 9. Silica phase present in chert and porcellanite from Site 307.

of the silica. This may explain the lack of bedding in the oldest chert from 304-15-1, which now consists of interlocking equant grains of microquartz (Plates 25 and 26).

\section{Breccia}

Breccias are restricted to cherts and porcellanites from Sites 303, 304, and 307 (Table 1). The breccias are similar in texture to those from the calcareous Mishash Formation (Campanian) in Israel described by Kolodny (1969).

Most of the Leg 32 breccias are in noncalcareous sediments and belong to three groups:

1) Fractured chert with little displacement of fragments. The conchoidal nature of the fracturing across undisturbed bedding indicates that it occurred after the silicification of the beds. The fragments are now silicified with clear chalcedony or megaquartz. Plates 18,23 , and 29 show examples of this type of breccia.
TABLE 1

Occurrence of Breccia and Drusy Quartz

\begin{tabular}{lcc}
\hline Hole & $\begin{array}{c}\text { Breccia } \\
\text { Core No. }\end{array}$ & $\begin{array}{c}\text { Drusy Quartz } \\
\text { Core No. }\end{array}$ \\
\hline $303 \mathrm{~A}$ & $2,3,5,6$, and 8 & 8 \\
304 & $4,5,7,8,10$, and 16 & $4,8,10,11,15$ \\
305 & - & 37,56 \\
306 & - & 38 \\
307 & 11 & $2,6,8,11,12,13$ \\
$310 \mathrm{~A}$ & - & - \\
313 & - & 17 \\
\hline
\end{tabular}

2) Fragments of both porcellanite and chert with random orientation. For example, Plate 23, Figure 1 contains fragments larger than $5 \mathrm{~cm}$, now oriented with their bedding vertical and cemented by dark brown chalcedony.

3) Fragments with disturbed bedding and gradational margins silicified with clear chalcedony. This texture indicates that the sediment was not completely silicified when the disturbance occurred. Examples of this type occur in 303A-5-2 and 304-4, CC (Plates 18 and 23).

These breccias are probably caused by differential compaction of porous, unlithified clays between the silicified layers or lenses. The absence of chert breccias in the Group 1 sites is due to the more nodular nature of the chert and less compaction in the carbonate. The calcareous porcellanites do not fracture, perhaps, because they are partly compacted, and the carbonate recrystallized prior to silicification. The movement which forms the breccias is one which enables fragments to separate rather than be compressed.

\section{Veins and Cavities}

Cavities lined with drusy quartz occur in cherts from six sites and are restricted to sediments with a low carbonate content (Table 1). Euhedral quartz crystals are up to $2 \mathrm{~mm}$ in length (Plate 25). Other cavities are lined by porcellanite (Plate 1, Figure 7) or botryoidal chalcedony (Plate 27, Figure 1). The cavities have irregular shapes, but are usually elongate along the bedding. Cavities are not present in the nodular cherts from the calcareous sequences. The cavities may be caused by fracturing, solution, or a volume change with the conversion of opal-CT to quartz. The absence of drusy quartz in calcareous sequences corresponds to the absence of cavities in which to grow.

Chalcedony veins are common in Cretaceous cherts and porcellanites from all sites (Plates 2, 3, 7, and 21). A second generation of fractures, usually filled with megaquartz and calcite, is present in some older cherts.

\section{Density, Porosity, and Sonic Velocity}

The Cenozoic clays and siliceous ooze from Sites 303 and 304 have porosities of $75 \%$ to $85 \%$ and the carbonate oozes from Sites 305 and 310 have $55 \%$ to $65 \%$ porosity. The diagenetic changes, including silicification, in similar lithologies of Cretaceous age have resulted in decreased porosities and increased wet bulk density as shown for porcellanites and cherts in Table 2. The wet bulk densities vary from 1.95 to $2.66 \mathrm{~g} / \mathrm{cc}$ and the average grain density from 2.24 to $2.65 \mathrm{~g} / \mathrm{cc}$. Available porosity was calculated from these figures. 
TABLE 2

Density and Porosity of Cherts and Porcellanites

\begin{tabular}{|c|c|c|c|c|}
\hline Sample & $\begin{array}{l}\text { Wet Bulk } \\
\text { Density } \\
(\mathrm{g} / \mathrm{cc})\end{array}$ & $\begin{array}{l}\text { Average } \\
\text { Grain Density } \\
(\mathrm{g} / \mathrm{cc})\end{array}$ & $\begin{array}{c}\text { Available } \\
\text { Porosity (\%) }\end{array}$ & Lithology \\
\hline \multicolumn{5}{|l|}{ Hole $303 \mathrm{~A}$} \\
\hline $\begin{array}{l}3, \mathrm{CC} \\
5, \mathrm{CC} \\
6-1 \\
6-1\end{array}$ & $\begin{array}{l}2.61 \\
2.62 \\
2.61 \\
2.05\end{array}$ & $\begin{array}{l}2.60 \\
2.62 \\
2.61 \\
2.50\end{array}$ & $\begin{array}{c}2 \\
- \\
\overline{30}\end{array}$ & $\begin{array}{l}\text { Brown chert } \\
\text { Green chert } \\
\text { Chert } \\
\text { Porcellanite }\end{array}$ \\
\hline \multicolumn{5}{|l|}{ Hole 304} \\
\hline $\begin{array}{l}4, \mathrm{CC} \\
4, \mathrm{CC} \\
8-1 \\
9-1 \\
10-1 \\
11-1 \\
14, \mathrm{CC} \\
15-1\end{array}$ & $\begin{array}{l}2.05 \\
2.60 \\
1.95 \\
2.20 \\
2.66 \\
2.60 \\
2.62 \\
2.65\end{array}$ & $\begin{array}{l}2.24 \\
2.60 \\
2.24 \\
2.58\end{array}$ & $\begin{array}{l}15 \\
- \\
23 \\
24\end{array}$ & $\begin{array}{l}\text { Brown porcellanite } \\
\text { Yellow chert breccia } \\
\text { Tan porcellanite } \\
\text { Pale brown porcellanite } \\
\text { Dark brown chert } \\
\text { Brown chert } \\
\text { Brown chert } \\
\text { Green chert }\end{array}$ \\
\hline \multicolumn{5}{|l|}{ Hole 305} \\
\hline $\begin{array}{l}17-3 \\
21-6 \\
32, \mathrm{CC} \\
37-1 \\
40, \mathrm{CC} \\
47-1 \\
58, \mathrm{CC} \\
61-1\end{array}$ & $\begin{array}{l}2.62 \\
2.61 \\
2.61 \\
2.60 \\
2.05 \\
2.30 \\
2.64 \\
2.22\end{array}$ & $\begin{array}{l}2.33 \\
2.44 \\
2.56\end{array}$ & $\begin{array}{l}21 \\
10 \\
22\end{array}$ & $\begin{array}{l}\text { Gray chert } \\
\text { Yellow chert } \\
\text { White chert } \\
\text { Gray chert } \\
\text { Gray porcellanite } \\
\text { Gray porcellanite } \\
\text { Gray chert } \\
\text { Gray calcareous porcellanite }\end{array}$ \\
\hline \multicolumn{5}{|l|}{ Hole 306} \\
\hline $\begin{array}{l}6, \mathrm{CC} \\
8-1 \\
30, \mathrm{CC} \\
35, \mathrm{CC} \\
41, \mathrm{CC} \\
42, \mathrm{CC}\end{array}$ & $\begin{array}{l}2.07 \\
2.20 \\
2.60 \\
2.64 \\
2.61 \\
2.60\end{array}$ & $\begin{array}{l}2.40 \\
2.33\end{array}$ & $\begin{array}{l}14 \\
10\end{array}$ & $\begin{array}{l}\text { Calcareous porcellanite } \\
\text { Calcareous porcellanite } \\
\text { Gray chert } \\
\text { Gray chert } \\
\text { Greenish chert } \\
\text { Gray chert }\end{array}$ \\
\hline \multicolumn{5}{|l|}{ Hole 307} \\
\hline $\begin{array}{l}7-1 \\
7-1 \\
7-1\end{array}$ & $\begin{array}{l}2.62 \\
2.03 \\
2.52\end{array}$ & $\begin{array}{l}2.65 \\
2.26 \\
2.56\end{array}$ & $\begin{array}{r}2 \\
18 \\
3\end{array}$ & $\begin{array}{l}\text { Calcareous porcellanite } \\
\text { Brown porcellanite } \\
\text { Dolomitic porcellanite }\end{array}$ \\
\hline \multicolumn{5}{|l|}{ Hole $310 \mathrm{~A}$} \\
\hline $17, \mathrm{CC}$ & 2.62 & & & Black chert \\
\hline \multicolumn{5}{|l|}{ Hole 313} \\
\hline $\begin{array}{l}21, \mathrm{CC} \\
38-1\end{array}$ & $\begin{array}{l}2.29 \\
2.49\end{array}$ & $\begin{array}{l}2.44 \\
2.53\end{array}$ & $\begin{array}{l}9 \\
3\end{array}$ & $\begin{array}{l}\text { Gray porcellanite } \\
\text { Gray calcareous chert }\end{array}$ \\
\hline
\end{tabular}

As expected, the cherts have very little porosity (excluding large cavities), whereas the porcellanites commonly have porosities of $20 \%$ to $30 \%$, with the higher values occurring in noncalcareous porcellanites. Plate 19 , Figure 2 shows the porosity of porcellanite at high magnification; this can be compared to the adjacent chert.

Sonic velocities were measured for several samples. The cherts and porcellanites have higher sonic velocities with increasing density (decreasing porosity). The range of values for chert is 3.9 to $5.2 \mathrm{~km} / \mathrm{sec}$ and for porcellanites 2.2 to $3.0 \mathrm{~km} / \mathrm{sec}$. These physical properties should make interbedded cherts and sediments good seismic reflectors.

\section{MINERALOGY AND PETROGRAPHY}

Radiolarian tests, diatom frustules, sponge spicules, and silicoflagellates are all composed of opal-A when they are deposited. They have retained this structure where they exist in the Cenozoic sections of Sites 303, $304,305,306,307$, and 310 . Site 313 has the only Cenozoic (Eocene) authigenic quartz and opal-CT recovered.

An unusual aspect of Site 313 is the occurrence of a calcareous radiolarian ooze of early Eocene age in which the radiolarians are still opal-A. It occurs below upper and middle Eocene calcareous ooze containing opal-CT and quartzose chert but no radiolarians. The calcareous 
radiolarian ooze in Core $13-1$ is $48 \% \mathrm{CaCO}_{3}$ and partly lithified. When a piece was dissolved in dilute acid, a network of radiolarian tests remained. The sample was also treated with $\mathrm{H}_{2} \mathrm{O}_{2}$ to remove any organic matter and then examined with the SEM. The sediment was found to be held together by bridges of material between particles. This incipient cement may be amorphous silica; however, this could not be proved (Plate 17). Similar structures, although more threadlike, have been reported by Matter (1974) as organic growth during storage and this may be correct for samples not treated with $\mathrm{H}_{2} \mathrm{O}_{2}$.

The silicon content of the interstitial water from Sites 305,310 , and 313 varies with the biogenous silica fossils present in the calcareous sediment. Figure 10 shows the dissolved silica distribution against depth. The depth of the youngest chert at each site is also plotted. Site 305 has the highest silicon values between 0 and 40 meters where radiolarians and diatoms are common in the sediment. At Site 310, high silicon values persist down to 75 meters with the presence of radiolarians and diatoms; below this depth siliceous fossils are absent from the sediment. The constant low values of $150 \mu$ moles/1 $(\sim 10 \mathrm{ppm} \mathrm{SiO} 2)$ below 100 meters at these sites are from Cretaceous sediments containing quartzose chert. This value is approximately the saturation value for quartz (Morey et al., 1962).

At Site 313 radiolarians are most abundant in the interval 186 to 223 meters and it is here, in the Eocene, that the interstitial water has its highest silicon value. No diatoms are now present in this interval. It is significant that the highest measured value for silicon in the interstitial water $\left.(660 \mu \text { moles } / 1 \text { or } \sim 40 \mathrm{ppm} \mathrm{SiO})_{2}\right)$ occurs near the partially lithified radiolarians described earlier. This is below the first occurrence of opal-CT-rich porcellanite and chert. The saturation value for Eocene

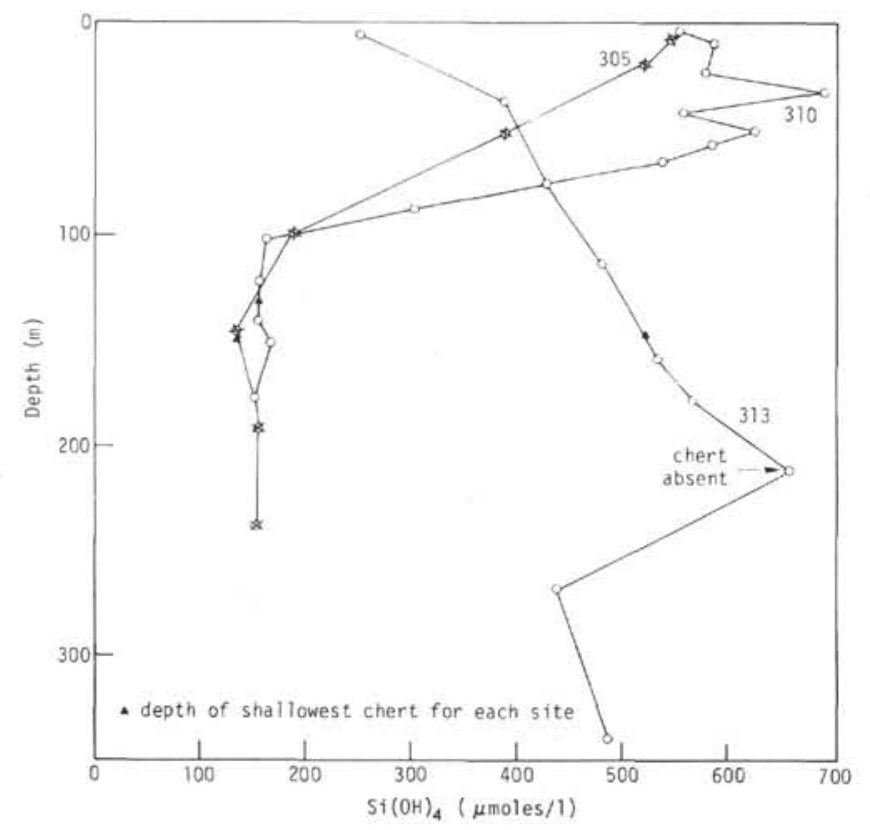

Figure 10. Distribution of dissolved silica in interstitial water with depth for Sites 305, 310, and 313. radiolarians is given as 27 to $35 \mathrm{ppm}$ at $2^{\circ} \mathrm{C}$ by Jones and Pytkowicz (1973, in Heath, 1974) which is less than the value of 50 to $80 \mathrm{ppm}$ at $0^{\circ} \mathrm{C}$ for amorphous silica obtained by Krauskopf (1959). Thus the dissolved silica associated with radiolarians at Site 313 is saturated with respect to opal-CT and could, at least locally, be saturated with respect to opal-A, resulting in precipitation. The high silicon content of the interstitial water should also retard dissolution.

Opal-CT was present in the sediment from Leg 32 in three forms:

1) Platy or bladed crystals occur in calcareous sediment and where there are open spaces in radiolarian clays. Plates $4,8,13$, and 14 show individual blades and clusters of blades which develop into spheres and hemispheres 6 to $30 \mu \mathrm{m}$ in diameter and which have been described by Wise et al. (1972) and others. The spheres need open space in which to develop. They are visible, under the microscope, lining the inside of foraminiferal chambers and radiolarian tests (Plates 4 and 13). The blades form clusters and become a siliceous cement (Plate 14) in a matrix of carbonate particles and other minor minerals.

2) Massive, porous opal-CT occurs in the noncalcareous porcellanites, in some chert of Cenozoic age, and in some calcareous porcellanites adjacent to chert nodules (Plates 4, 5, and 24, Figure 1). In some cases it has a granular texture visible with the SEM (Plate 19, Figure 2).

3) Opal-CT forms casts of some radiolarians in noncalcareous porcellanites (Plate 20). Thin section and SEM observations show the opal-CT to be massive with an irregular surface.

The noncalcareous porcellanites from Sites 303, 304, and 307 , composed of both opal-CT and quartz, have some or all of their quartz in the form of chalcedony filled radiolarian tests. Table 3 gives four point counts for thin sections of porcellanites containing the most radiolarians. In two cases all the quartz determined by $\mathrm{X}$-ray can be accounted for in the radiolarians, but in the others less than a third can be accounted for. None of the porcellanite samples shows radiolarians actually touching one another, nor do they form more than $22 \%$ of the rock. The highest density is in 307-4, CC (Plate 27). In contrast, the more silicified, or cherty layers, are rich in radiolarians, as illustrated in Plates 19 and 27. Here the radiolarians are almost touching.

The usual petrographic practice is to make thin sections perpendicular to bedding in order to examine the

TABLE 3

Radiolarian Content of Porcellanites (1000 point counts)

\begin{tabular}{lc}
\hline \multicolumn{1}{c}{ Sample } & $\begin{array}{c}\text { Chalcedony-Filled } \\
\text { Radiolaria as } \\
\text { \% of Whole Rock }\end{array}$ \\
\hline 303 A-3, CC & 12 \\
303 A-6-1 & 10 \\
$304-7-1$ & 8 \\
$307-4$, CC & 22 \\
\hline
\end{tabular}


composition and texture of the rock. For Sample 303A$3, \mathrm{CC}$ an additional thin section parallel to bedding was made and this exposed additional biogenous silica remains: radiolarian spines, sponge spicules, and coneshaped radiolarians (Nassellaria) are all common with long axes parallel to the bedding. The spines appear as chalcedonic pinpoints in the vertical section and their biogenic origin cannot be determined. There is no alignment of spicules to indicate a current direction (Plate 19, Figures 5 and 6).

Relic textures, including bedding, ripples, and burrowing, found in chert and similarly the calcareous fossils that are now silicified, provide ample evidence for the replacement origin of deep-sea chert. The silicification includes actual particle replacement as well as precipitation in the pores and dissolution of original sediment. By examining the porcellanites and cherts recovered, the following replacement sequence can be established for a foraminiferal nannofossil ooze (93\% to $\left.95 \% \mathrm{CaCO}_{3}\right)$ which now, at least, contains no radiolarians (see Plates 14, 15, and 16):

1) Plates of opal-CT are precipitated in the interstices of the sediment and in the foraminiferal chambers.

2) The plates join and grow to form spherical and hemispherical masses of opal-CT inside foraminiferal chambers, and growing out from their tests into the carbonate matrix forming a cement.

3) The carbonate matrix, mainly nannofossil remains, dissolves or is replaced by silica. In some cases nannofossils with calcitic overgrowths resist silicification and form inclusions of calcareous porcellanite in the chert.

The next three events occur along a boundary, common in many nodules, between calcareous porcellanite and chert (Plates 5, 8, and 13).

4) The opal-CT rarely fills the chambers and chalcedony is precipitated in the remaining space.

5) The calcite foraminiferal test is replaced by chalcedony, never opal-CT. Larger crystals of carbonate, such as dolomite rhombs or echinoid spines (Plate 1, Figure 3 and Plate 28, Figure 5) may be preserved or replaced later.

6) The conversion of opal-CT to chalcedony. This is not always complete and some opal-CT may remain to be converted later (Plates 11 and 12).

The above sequence of events was followed in the formation of both nodular and bedded Tertiary porcellanite and chert from Site 313. Such cherts either contain small areas of opal-CT or have relic spheres which were previously opal-CT but are now chalcedony (Plates 2,10 , and 12). Replacement follows the basic sequence described by Heath and Moberly (1971). The presence of a few relic spheres, now chalcedony, in most Cretaceous nodular cherts examined indicates that the initial precipitation of some silica was as opal-CT. From this evidence it appears that the ratio of opal-CT to quartz during the formation of chert in calcareous sediments may vary from very low to high. The conditions favorable for opal-CT formation are described later. If the environment is not suitable or becomes unsuitable for opal-CT formation then, as Lancelot (1973) and Greenwood (1973) have suggested, direct precipitation of quartz alone will occur. The ratio of opal-CT to quartz is lower if the original carbonate sediment had a high foraminiferal content. This results because the foraminiferal tests are always replaced by quartz and their empty chambers may be filled by direct precipitation of quartz.

The formation of the massive radiolarian-rich calcareous porcellanites, common in Sites 305, 306 , and 310 , may follow a sequence starting with a sediment similar to the calcareous radiolarian ooze of 313-13:47 to $74 \% \mathrm{CaCO}_{3}$ and the remainder as opal-A with minor clay. The sequence is:

1) Dissolution of diatoms and partial dissolution of radiolarians with precipitation in pores of silica, as platy and massive opal-CT or perhaps as opal-A, linking particles of both biogenic silica and recrystallized carbonate. The coarser discoaster and coccolith crystals, often overgrown with calcite, are usually not replaced by silica. If they are replaced, then chalcedony has replaced them.

2) Filling of radiolarian and foraminiferal tests and replacement of test by chalcedony.

3) Conversion of opal-CT to cryptocrystalline chalcedony.

If the above sequence occurs over a stratigraphic interval, perhaps several meters thick, then the result will be a bedded, calcareous porcellanite with some lenses of chert where the silicification was more successful. Most of the porous porcellanite however, will consist of recrystallized carbonate and radiolarian molds cemented with silica.

The replacement sequence in a noncalcareous radiolarian clay is different:

1) The dissolution of diatoms and radiolarians occurs.

2) The undissolved radiolarian tests convert to massive opal-CT (Plate 20).

3) The clay matrix and any clay in radiolarian tests is impregnated with massive opal-CT. Spheres of opal-CT are restricted to open voids, mainly inside radiolarian tests (Plate 4). Chalcedony is precipitated in tests not filled with sediment or opal-CT, and may also form veins.

4) The opal-CT radiolarian tests of (2) convert to chalcedony (Plate 27, Figure 9).

5) The remaining opal-CT is then converted to chalcedony along a fairly sharp boundary with only some pockets remaining to be converted later.

6) Fracturing and cementation with drusy quartz and chalcedony occur. Some chalcedony may convert to microquartz.

At the base of Sites 305, 306, and 307 there is some replacement of silica by calcite. This is shown by the replacement of a radiolarian test by calcite (Plate 7, Figure 5).

At Site 307, barite crystals are replaced by length-slow chalcedony in a dolomitic porcellanite. The replacement postdates the formation of the porcellanite because the barite is associated with a late fracture. The occurrence of length-slow chalcedony in deep-sea cherts is contrary to the evaporitic environmental interpretation placed on it by Folk and Pittman (1971). 
Several occurrences of dark brown needle clusters, similar to those illustrated by Lancelot (1973, fig. 11) and tentatively identified by him as rutile, are present as inclusions in chalcedony (Plate 18). In addition, a sample of drusy quartz has identical needles growing on the prism faces of the quartz, and in some cases they are partly engulfed by the quartz growth. Their cation composition was determined, using element maps, to be entirely iron and manganese. Three mineral species probably are present but were not identified (Plate 26). In some samples radiolarian tests are replaced or coated by opaque iron and manganese minerals. The actual time of this replacement is not clear, but it is usually prior to silicification (Plate 21).

In general the contact between chert and the surrounding sediment is not sharp but consists of a zone of porcellanite. The porcellanite is usually calcareous if the surrounding sediment is calcareous. The outer boundary of this zone is either between porcellanite and nonsilicified sediment or less-silicified sediment. Because of its softness, the outer boundary with nonsilicified sediment is rarely preserved. The porcellanite has a sharp boundary with the chert and this reflects the mineralogy; the chert is mainly chalcedony whereas the porcellanite is opal-CT or chalcedony with clays or carbonate. In some cases there is a concentration of opaque material along the chert-porcellanite boundary (Plate 24). This material could be a concentration of clay minerals (Lancelot, 1973) but may include iron and manganese minerals and organic matter. Three polished samples were analyzed to determine the distribution of cations across such boundaries. The results, given in Table 4 as ratios with respect to silica, show a marked increase in $\mathrm{K} / \mathrm{Si}$ and $\mathrm{Fe} / \mathrm{Si}$ and a smaller increase in $\mathrm{Al} / \mathrm{Si}$ ratio in the porcellanite zone relative to the chert. The only other elements detected in these samples were calcium in the calcite and trace amounts of magnesium, manganese, and, in one case, sulfur. It is hard to recognize a concentration of cations in the porcellanite compared to the surrounding unsilicified sediment because the precipitation or replacement by silica dilutes the cation concentration.

Greenish chert from 303A-5, CC and 304-8-1 is associated with a gray porcellanite in an otherwise brown chert and porcellanite sequence (Plates 22 and 24). Silicic volcanic glass, clinoptilolite, and montmorillonite are common in the gray clay with the porcellanite in 303A-5, CC. This layer also coincides with particularly hard drilling, suggesting more extensive silicification. Samples of chert from these two cores together with cherts from 303A-7, CC, 304-15-1, 305-17-
4, and 313-10, CC were polished and their cathodoluminescence examined. The later samples had orange luminescence, whereas in Samples 303A-5, CC and 3048-1 the chalcedony-filled radiolarians and chalcedony vein showed orange luminescence and the groundmass was pale blue. Orange luminescence is common for authigenic quartz but blue luminescence is reported to be restricted to quartz formed at high temperatures (Smith and Stenstrom, 1965). The blue luminescence may be due to organic matter or volcanic glass. In addition, both of these cherts are from sediments of the same age, Barremian to Hauterivian, and correlate with a layer in $307-5, \mathrm{CC}$ containing volcanic glass.

\section{DISTRIBUTION OF SILICEOUS SEDIMENTS}

Due to the drilling process and the hardness of the chert, recovery was poor in chert-bearing sections. Because of this, it was difficult to estimate the true ratio of chert to porcellanite and other lithologies. However, some general trends can be seen despite this problem.

The lack of porcellanite and chert at three sites can be explained by a single factor: lack of a silica source. Sites 308 (68.5 m penetration) and 309 (12 m penetration) on Koko Guyot, are in water shallower than 1500 meters; Site 311 ( $37 \mathrm{~m}$ penetration) is on the archipelagic apron of the Hawaiian Ridge. Siliceous fossils are absent from all three sites. The sediments at these sites are mostly calcareous with mafic volcanic detritus and, in Site 311, some pelagic clay. If biogenous silica were present, the relatively young age of the sediments and their shallow burial depth would not favor chert formation. Previous deep-sea drilling has shown that most chert is of Eocene age or older; of the three Sites where no chert was found, only Site 308 recovered sediment of Eocene age. Here the lack of siliceous fossils, because of the low productivity of the overlying water during the Eocene, excluded the possibility of chert formation.

The presence or absence of biogenic chert in a particular stratigraphic interval is a reflection of the biological productivity of the overlying ocean at that time. The biogenous silica in surface sediments for the North Pacific is given by Lisitzin (1972) and shows zones of high concentration near the equator, off Japan, and in the higher latitudes. The northward movement of the Pacific plate and the high productivity near the equator during the Cenozoic are well documented (for example, Winterer, 1973; van Andel, 1974; Lancelot and Larson, this volume). As the plate moves horizontally, it also sinks vertically according to an empirical curve derived by Sclater et al. (1971). Thus the sediment reflects the depth of the CCD and the productivity of the overlying

TABLE 4

Ratios of Elements Near the Boundary Between Porcellanite and Chert

\begin{tabular}{c|c|c|c|c|c|c|c}
\hline \multirow{2}{*}{$\begin{array}{c}\text { Elements } \\
\left(\text { ratio } \times 10^{3} \text { ) }\right.\end{array}$} & \multicolumn{2}{|c|}{$306-3, \mathrm{CC}$} & \multicolumn{3}{c|}{$306-12, \mathrm{CC}$} & \multicolumn{2}{c}{$304-8,1$} \\
\cline { 2 - 8 } & $\begin{array}{c}\text { Calcite and } \\
\text { Opal-CT }\end{array}$ & Chert & $\begin{array}{c}\text { Calcite and } \\
\text { Opal-CT }\end{array}$ & Opal-CT & Chert & Opal-CT & Chert \\
\hline $\mathrm{Al} / \mathrm{Si}$ & $11-14$ & $8-9$ & 11 & $4-8$ & $6-7$ & 8 & $6-9$ \\
$\mathrm{~K} / \mathrm{Si}$ & $16-38$ & $3-4$ & $13-15$ & $9-12$ & 8 & $13-15$ & $3-8$ \\
$\mathrm{Fe} / \mathrm{Si}$ & $13-24$ & $4-6$ & $18-22$ & $10-13$ & $8-9$ & $17-20$ & $8-9$ \\
\hline
\end{tabular}


surface water. There is an absence of chert in Eocene sediments on Shatsky and Hess rises because during the Eocene they were already north of the high-productivity equatorial zone (van Andel, 1974). Site 313, which does contain middle and lower Eocene chert, was within $10^{\circ}$ of the equator during the Eocene. Similarly, the deep water Sites 303, 304, and 307 were within the central gyre zone of low productivity, and thus the Eocene is either absent or very thin at these sites and contains no chert. The presence of siliceous fossils in the Neogene sections at Sites 303, 304, and 310 indicates either their northward shift into the Kuroshio extension current and the higher productivity of siliceous plankton in the northern latitudes or the commencement of that circulation system.

Stratigraphic levels where there is more calcareous porcellanite generally coincide with increased radiolarian and sometimes clay contents compared to calcite. This pattern probably represents either a change in the position of the sea floor relative to the calcite compensation depth-lysocline system, or a change in the productivity of siliceous plankton relative to calcareous plankton. The latter is more likely because the sedimentation rates remain high.

Sediments of Maestrichtian and late Campanian age were sampled at Sites 305,310 , and 313 and contained less chert than the older Cretaceous sediments. This is also found by Lancelot (1973) for other sites in the North Pacific.

\section{FORMATION OF CHERT AND PORCELLANITE}

\section{Source of Silica}

Recognizable siliceous fossils are common to abundant in most of the cherts examined and it is the biogenous material that provides the bulk of the silica needed to form deep-sea chert. This conclusion was also reached by Heath and Moberly (1971), Ramsay (1971), Wise et al. (1972), and others. However, the radiolarians and spicules preserved in the cherts and porcellanites have not contributed their silica to the silicification of the sediment unless they are now replaced by a mineral other than silica. It is the dissolved siliceous fossils that have provided the silica and their former presence cannot be determined visually. In fact, they need not have existed even within the now-silicified layer, but may have dissolved elsewhere and the silicon migrated in solution to the site of silicification. Some chert nodules contain radiolarian tests where none exists in the adjacent carbonate sediment (Plates 1 and 9, Figure 2a). The radiolarians in the carbonate dissolved, providing silica for the chert.

The recognizable siliceous remains form only a small part of the silica, even in a densely packed radiolarian chert. The radiolarians in the chert range in size from 50 to $300 \mu \mathrm{m}$ suggesting that dissolution was not merely of small radiolarians leaving the larger more robust ones to survive. No diatoms were recognized in the cherts, porcellanites, or Eocene siliceous sediments, and their absence may indicate that they dissolved and contributed their silica. Diatoms have been sampled with volcanic clay of Maestrichtian age in the Indian Ocean (Site 216) and with silicified layers of Late Cretaceous age in the Southern Ocean (Site 275). Thus diatoms have been a potential source of silica to form cherts since the Late Cretaceous.

Traces of siliceous fossils are absent or rare in chert samples of microquartz or chalcedony with a uniform grain size of 15 to $20 \mu \mathrm{m}$. Such samples are restricted to a few nodules in carbonate and the oldest chert at Site 304 . They may have formed either by direct precipitation and replacement by quartz of carbonate sediment with a uniform texture and no radiolarians or by recrystallization of the chalcedony with time.

A volcanic source for some silica in the cherts and porcellanites from 303A-5, CC and 304-8-1 is suggested by the associated assemblage of volcanic glass, clinoptilolite, and montmorillonite, and the Barremian to Hauterivian age. Interestingly, the noncalcareous porcellanite and shale on Shatsky Rise is also of this age and contains minor clinoptilolite; some silica there may have a volcanic origin. The lack of recognizable shards or ash in these siliceous rocks may either mean it was not preserved or that the silica migrated from nearby beds which do contain devitrified volcanic glass. A volcanic origin for some chert in the Atlantic, associated with a similar mineral assemblage, has been suggested by Calvert (1971) and Gibson and Towe (1971).

Additional silica may be released by the diagenetic alteration of volcanically derived clays as proposed by Keene and Kastner (1974). Although more illite than montmorillonite is associated with cherts in a few cases (304-3, 307-3, 307-11, 306-8, and 306-29, Zemmels and Cook, this volume), it was not possible to prove the authigenic origin of the illite.

\section{Time of Formation}

The early formation of some chert is indicated by:

1) The compaction of beds around nodules (Plate 6, Figure 1).

2) The discovery of a chert fragment within a fracture in the basaltic basement (304-16-1).

It is possible that (1) happened after a considerable time, such as 40 to 50 m.y., when the overburden became significant and lithification occurred in the surrounding sediment. It is not unusual to sample unlithified porous Eocene sediment. Similarly, the fracturing mentioned by Lancelot (1973) as evidence for early formation of chert only means the chert formed prior to lithification of the limestone. The chert fragment in the basalt may be a special case where higher in situ temperatures near the ridge crest encouraged the early formation of chert. The fragment contains radiolarians and was lithified prior to its deposition in the fracture.

Later formation of some chert is suggested by the existence of radiolarian ooze of early Eocene age, such as that at Site 313, Core 13. This silica-rich $\left(>50 \% \mathrm{SiO}_{2}\right)$ sediment must eventually become chert, or at least silicified carbonate. In addition, silicified beds depressed around a nodule and a chalcedony vein (Plates 3 and 6) postdate the nodule and vein.

A dolomitic porcellanite (Plate 28) from Site 307 formed after the authigenic growth of the dolomite rhombs as shown by the rhombs also being present in 
the surrounding nannofossil ooze. The porcellanite formed when the micritic matrix was replaced by silica, which is now chalcedony. Similarly, recrystallized carbonate was replaced, micrite first, by silica in samples from Sites 305, 306, and 310. The larger carbonate crystals remain preserved in the chalcedony (Plates 2, 6, and 9). In addition, the termination of chert nodules by veins indicates the chert postdates the vein. Similarly, the silicification of the breccia matrix and the growth of drusy quartz, are late events.

The nature of the source of silica may also determine when silicification occurs. For example, in the diagenetic history of the rock the supply of silica from volcanic glass and clays may become available later than biogenous silica.

The evidence suggests that, except in areas where there is high in situ temperatures, early (i.e., $<10$ m.y.) chert formation is unlikely and some, if not most porcellanites and cherts may require 40 to 50 m.y. to form. The Quaternary and Neogene siliceous oozes, both calcareous and noncalcareous, should eventually become porcellanite or chert.

\section{Site and Method of Formation}

The site of chert formation is controlled by the texture and composition of the host sediment, provided there is enough silica. Chert forms both by replacement of the original sediment and by impregnation of the pores. The carbonate or clay content of the original sediment decreases, relative to the whole, as more silica impregnates the rock, fills voids, and replaces other minerals. The porosity of porcellanite and chert indicates the extent of silicification at that location and is not related to the amount of overburden; a dense chert may be adjacent to a carbonate ooze with $60 \%$ to $70 \%$ porosity.

The ratio of foraminifera to nannofossils in calcareous sediment as well as the quantity of siliceous fossils are important in determining the site of chert formation. For a carbonate sediment with initially low biogenous silica (for example, $10 \%$ to $40 \%$ ), the individual diatoms and radiolarians dissolve and supply the silica to form chert nodules at favorable locations. The higher the ratio of foraminifera to nannofossils, and the less clay, the more favorable the location. The foraminifera contain voids allowing silica to migrate and precipitate. Such a sediment, according to Schlanger and Douglas (1974) is also favored for lithification by calcite transfer from foraminifera and some coccoliths to overgrowths on discoasters and other coccoliths. Nannofossil ooze has an effect similar to clays in retarding silicification because of lower porosity and permeability. An example is the silicification of foraminiferal sand forming the base of turbidite layers in Cores 313-5 (late Eocene) and 313-10 (early Eocene). No radiolarians are recognizable in this chert, and it is unlikely they would have been deposited with foraminifera if these beds were deposited from a turbidity current. Sorting would locate the radiolarians in the upper part of the graded beds. The role of permeability has also been emphasized by Lancelot (1973).

The presence of organic matter, pyrite, and barite in some dark gray cherts from Sites 305,306 , and 310 is a further example of the well-known, but poorly understood, association of organic matter and silica. Siever (1962) suggested a hypothesis involving organic absorption on the silica surfaces which reduced its solubility and allowed a concentration gradient to be set up, enabling diffusion of silica from surrounding sediment where the silica could dissolve. There is improvement in radiolarian preservation near organic-rich sediments from 305-64 and this may have promoted chert formation at that location.

A general silicification of the whole stratum occurs in carbonate sediment with abundant $(>50 \%)$ biogenous silica and some clay. This results in a bedded calcareous porcellanite but with some chert stringers along more permeable layers. The beds with more radiolarian remains in the noncarbonate environment are more silicified (Plate 24, Figure 2). Here the low permeability of clays allows the interlayering of laminae with different degrees of silicification and probably represents an original difference in the composition of the layers. It is possible that the more porcellaneous layers contain authigenic clays and have supplied some of their silica to the adjacent cherty layers.

The mineralogy of the cherts and porcellanites is determined by the associated sediments, together with age and the concentration of silica in the interstitial water. Increased depth of burial and high in situ temperatures, as suggested by Heath (1973), will speed up the transitions that occur in chert formation. When the porcellanite data from Figures 3 to 9 are plotted on a calcite-quartz-opal-CT diagram, a pattern emerges that is a function primarily of sediment type and time. Figure 1la plots Cretaceous porcellanites that contain, or are in, sediments of Albian age or younger ( $\sim 65$ to 105 m.y.). Interestingly, the samples that contain no calcite have a high opal-CT to quartz ratio; those that contain calcite have a wide range of opal-CT to quartz ratios depending on their clay content. The calcareous porcellanites with more opal-CT are found above and below the volcanic sediment in Site 313 where the clay content is relatively high. Others form the margins of chert nodules where there is a concentration of impurities such as clays.

The pre-Albian samples (105 to 130 m.y.), Figure 11b, have an entirely different distribution; the samples that contain opal-CT contain no calcite, those that contain calcite contain no opal-CT. The exceptions are 305-65 and 306-12, both located adjacent to noncalcareous clay layers in otherwise carbonate sequences. This emphasizes the role of lithology in controlling the silica phase; in clayey facies opal-CT is more abundant and persists longer than in carbonate facies. There is no evidence to suggest that the opal-CT simply formed more recently. The two Cenozoic calcareous porcellanites analyzed fall on the calcite-opal-CT composition line.

Table 5 lists the oldest opal-CT occurrence at each site. Opal-CT in the oldest sediment is in noncalcareous porcellanites from the three deep-water sites: 303,304 , and 307. The Valanginian age of this opal-CT makes it the oldest opal-CT from the Pacific and probably from any of the oceans. The opal-CT from Site 50 on Shatsky Rise analyzed by Greenwood (1973) is associated with 


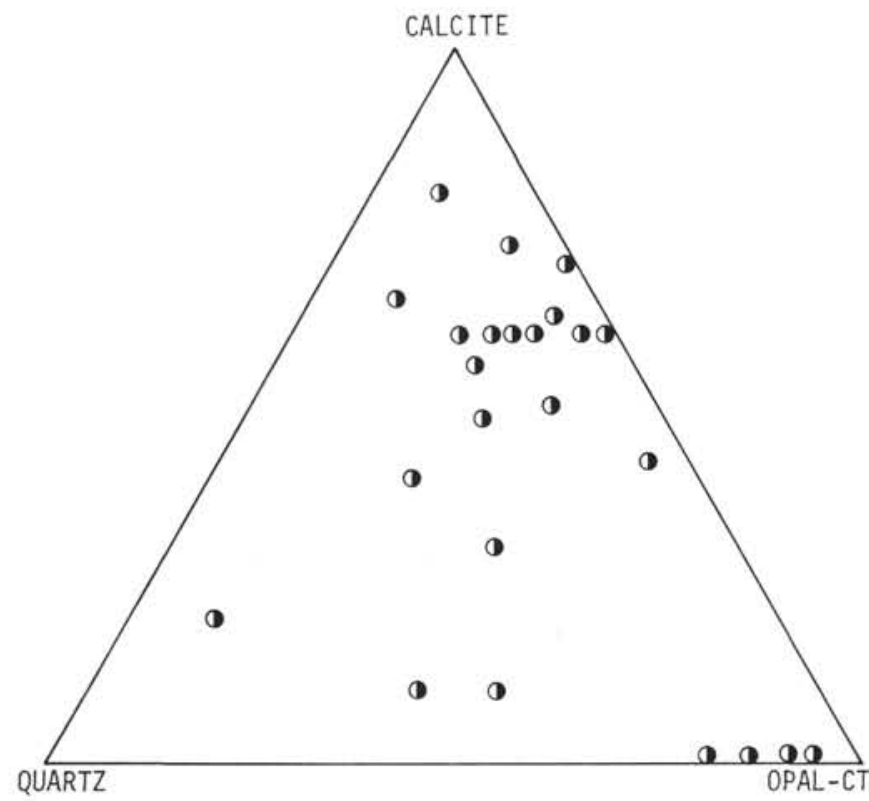

(a) ALBIAN and POST-ALBIAN ( 65 to $105 \mathrm{~m} . \mathrm{y}$.)

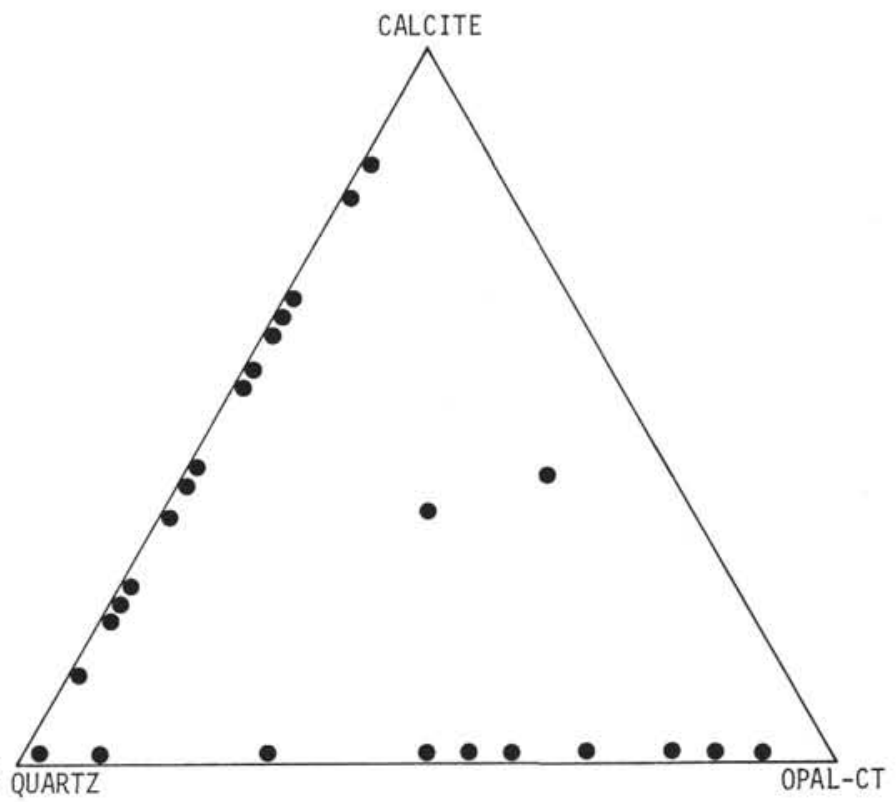

(b) PRE-ALBIAN ( 105 to 130 m.y.)

Figure 11. Mineralogy of Cretaceous porcellanites.

TABLE 5

Oldest Opal-CT Recovered at Each Site

\begin{tabular}{llc}
\hline Site-Core & \multicolumn{1}{c}{ Stage } & $\begin{array}{c}\text { Approximate } \\
\text { Age (m.y.) }\end{array}$ \\
\hline $303-7 \mathrm{~A}$ & Hauterivian to Valanginian & $118-130$ \\
$304-9,11$ & Barremian to Valanginian & $112-130$ \\
$307-7$ & Hauterivian to Valanginian & $118-130$ \\
$306-12$ & Early Aptian to Barremian & $110-118$ \\
$305-65$ & Early Aptian to Barremian & $110-118$ \\
$310-17 \mathrm{~A}$ & Early Cenomanian to late Albian & $96-103$ \\
$313-42$ & Early Campanian & 75 \\
\hline
\end{tabular}

sediments of early Barremian to late Hauterivian age (Douglas and Moullade, 1972) and not Late Jurassic, as stated in the DSDP Leg 6 Initial Report (Fischer, Heezan, et al., 1971). Opal-CT was reported in the Atlantic (Site 4-4) in marly sediment of Hauterivian age (Rex, 1969). Also, at Sites 303, 304, and 307, the sharp increase in quartzose porcellanite with depth coincides with the first occurrence of carbonate. There is no recognizable disconformity where this change in silica mineralogy occurs; within the same core (307-7) noncalcareous porcellanite contains opal-CT, whereas the adjacent calcareous porcellanite is quartzose.

Sites 305 and 310 on Shatsky and Hess rises have the highest opal-CT to quartz ratio near the base of each hole associated with noncalcareous clays (Figures 3a and 5). The oldest opal-CT from Shatsky Rise is in a Lower Cretaceous noncalcareous massive porcellanite. The porcellanite contains radiolarians composed of opal-CT and underlies a thick sequence of quartzose calcareous porcellanite and cherts.

The role of sediment texture and composition in determining the silica phase is further emphasized by the breccia from Site 304-5 (Plate 23) where some fragments are opal-CT porcellanite now in a matrix of chalcedony.
Chalcedony, rather than opal-CT, forms the cement probably because of the lower silica concentrations in the interstitial water at that time. Some fragments have remained opal-CT because of the presence of clays. Similarly, burrows often have a texture different from the surrounding sediments. Plate 11 shows burrows consisting of opal-CT whereas the surrounding chert is quartz.

Only the Cenozoic cherts and those associated with clays contain significant amounts of opal-CT. The cherts associated with carbonate at Sites 303, 304, 305, 306,307 , and 310 are all quartzose. This emphasizes the role of lithology in the transformation of opal-CT to quartz. The change is relatively faster in carbonate sediments than in clayey sediments.

Ultimately, of course, the opal-CT porcellanites will convert to quartz, although they could persist in the oldest noncarbonate sediment in present-day oceans. The environment favoring opal-CT preservation rather than quartz is that suggested by Millot (1964) and Lancelot (1973): a higher concentration of foreign cations. This is found in clay-rich environments. The clays may be present locally in carbonate, forming a microenvironment, as well as in noncarbonate facies. The clay need only form a minor part of the sediment for at least some opal-CT to form. This is illustrated in Plate 11, Figure 6 where a foraminifer has one chamber filled with opal-CT, and the adjacent chamber is only partly filled with opal-CT, the remaining space is filled with chalcedony. Whether opal-CT is precipitated or not is dependent on the silica content of the interstitial waters remaining above the saturation value for opalCT.

\section{CONCLUSIONS}

The following conclusions are drawn from evidence provided by Leg 32 cherts and porcellanites: 
1) The distribution of deep-sea cherts can be explained by paleogeography. For example, the absence of Eocene chert at several sites is because these sites were north of the high-productivity equatorial zone during the Eocene.

2) The time of silicification varies with the nature of the original sediment. Bedded calcareous porcellanite with chert lenses may not form from a radiolarian-rich carbonate sediment for 40 to 50 m.y. after burial. Silicification in these rocks postdates the precipitation of calcite overgrowths on nannofossils and, in one case, the formation of dolomite rhombs. Most chert nodules form earlier in calcareous ooze which originally contained relatively few siliceous fossils. Chert formation is hastened by high-energy conditions, as also noted in previous studies.

3) The biogenous source of most silica for deep-sea chert and the replacement origin of this chert is confirmed. Diatoms, because they dissolve more readily, have provided silica since at least the Late Cretaceous.

4) The occurrence of opal-CT in a clay-rich noncalcareous layer beneath calcareous quartzose porcellanites emphasizes the importance of lithology, as suggested by previous workers, in determining the nature of the silica phase precipitated. The amount of opal-CT initially deposited is controlled by the microenvironment and the amount of silica in the interstitial water. Some relic opal-CT spheres can be seen in most chalcedonic cherts from calcareous sequences. Opal-CT persists longer where it forms massive porcellanties in noncalcareous clay sequences. In a calcareous environment opal-CT is usually the first silica phase to precipitate.

5) A volcanic source for some silica is indicated by the association of devitrified silicic volcanic glass, clinoptilolite, and montmorillonite interbedded at one horizon with greenish-gray chert.

6) The direct precipitation of quartz occurs inside radiolarian and foraminiferal tests, in veins and cavities, and replaces calcite and barite. Quartz-filled fractures indicate several periods of silicification. In the deeper cherts and porcellanites silica may be replaced by calcite.

7) The actual site of chert formation is controlled by the texture and composition of the sediment. This confirms the results of others. Silicification prefers permeable porous sediment such as provided in a carbonate environment by a high foraminifera to nannofossil ratio and in a clayey environment by radiolarian-rich layers. A high organic content in the sediment may also favor chert formation.

\section{ACKNOWLEDGMENTS}

I would like to thank Dr. Miriam Kastner and Dr. E. L. Winterer for their helpful discussions and suggestions. Fellow shipboard scientists also encouraged the study. Ms. Ellen Flentye assisted with the SEM and Ron LaBorde with the analytical facilities. The work could not have been done without the time and skill of Mr. and Mrs. Roy DeHaven in preparing over 100 thin sections. Financial support from the Office of Naval Research and DSDP (National Science Foundation) was appreciated.

\section{REFERENCES}

Calvert, S. E., 1971. Composition and origin of North Atlantic deep-sea cherts: Contrib. Min. Petrol., v. 33, p. 273-288.

Cook, H. E., Johnson, P. D., Matti, J. C., and Zemmels, I., in press. Methods of sample preparation and X-ray diffraction data analysis, X-ray mineralogy laboratory. In Hayes, D., Frakes, L. A., et al., Initial Reports of the Deep Sea Drilling Project, Volume 28: Washington (U.S. Government Printing Office).

Douglas, R. G. and Moullade, M., 1972. Age of the basal sediments on the Shatsky Rise, Western North Pacific Ocean: Geol. Soc. Am. Bull., v. 83, p. 1163-1168.

Fischer, A. G., Heezen, B.C., et al., 1971. Initial Reports of the Deep Sea Drilling Project, Volume 6: Washington (U.S. Government Printing Office).

Folk, R. L. and Pittman, J. S., 1971. Length-slow chalcedony: a new testament for vanished evaporites: J. Sediment. Petrol., v. 41, p. 1045-1058.

Gibson, T. G. and Towe, K. M., 1971. Eocene volcanism and the origin of horizon A: Science, v. 172, p. 152-153.

Greenwood, R., 1973. Cristobalite: its relationship to chert formation in selected samples from the Deep Sea Drilling Project: J. Sediment. Petrol., v. 43, p. 700-708.

Heath, G. R., 1973. Cherts from the Eastern Pacific, Leg 16, Deep Sea Drilling Project. In van Andel, Tj. H., Heath, G. R., et al., Initial Reports of the Deep Sea Drilling Project, Volume 16: Washington (U.S. Government Printing Office), p. 609-613.

1974. Dissolved silica and deep-sea sediments. In Hay, W. W. (Ed.), Studies in paleooceanography: SEPM Spec. Pub., No. 20, p. 77-93.

Heath, G. R. and Moberly, R., 1971. Cherts from the Western Pacific, Leg 7, Deep Sea Drilling Project. In Winterer, E. L., Riedel, W. R., et al., Initial Reports of the Deep Sea Drilling Project, Volume 7: Washington (U.S. Government Printing Office), p. 991-1007.

Jones, J. B. and Segnit, E. R., 1971. The nature of opal. I. Nomenclature and constituent phases: J. Geol. Soc. Australia, v. 18 , p. 57-68.

Keene, J. B. and Kastner, M., 1974. Clays and formation of deep-sea chert: Nature, v. 249, p. 754-755.

Kolodny, Y., 1969. Petrology of siliceous rocks in the Mishash Formation (Negev, Israel): J. Sediment. Petrol., v. 39, p. 166-175.

Krauskopf, K. B., 1959. The geochemistry of silica in sedimentary environments. In Ireland, H. A. (Ed.), Silica in sediments: SEPM Spec. Pub., No. 7, p. 4-19.

Lancelot, Y., 1973. Chert and silica diagenesis in sediments from the Central Pacific. In Winterer, E. L., Ewing, J. I., et al., Initial Reports of the Deep Sea Drilling Project, Volume 17: Washington (U.S. Government Printing Office), p. $377-405$.

Larson, R. L. and Chase, C. G., 1972. Late Mesozoic evolution of the Western Pacific Ocean: Geol. Soc. Am. Bull., v. 83 , p. $3627-3644$.

Lisitzin, A. P., 1972. Sedimentation in the world ocean: SEPM Spec. Pub., No. 17, 218 p.

Mann, R. and Gieskes, J. M., in press. Interstitial Water Studies, Leg 28. In Hayes, D., Frakes, L. A., et al., Initial Reports of the Deep Sea Drilling Project, Volume 28: Washington (U.S. Government Printing Office).

Matter, A., 1974. Burial diagenesis of pelitic and carbonate deep-sea sediments from the Arabian Sea. In Whitmarsh, R.B., Ross, D.A., et al., Initial Reports of the Deep Sea Drilling Project, Volume 23: Washington (U.S. Government Printing Office), p. 421-469. 
Millot, G., 1964. Geologie des Argiles: Paris (Masson et Cie).

Morey, G.W., Fournier, R.O., and Rowe, J.J., 1962. The solubility of quartz in water in the temperature interval from $25^{\circ}$ to $300^{\circ} \mathrm{C}$ : Geochim. Cosmochim. Acta, v. 26, p. 1029-1043.

Muiller, G. and Gastner, M., 1971. The "Karbonat-Bombe", a simple device for the determination of the carbonate content in sediments, soils and other materials: N. Jb. Miner. Mh., v. 10, p. 466-469.

Mullin, J.B. and Riley, J.P., 1955. The colorimetric determination of silicate with special reference to sea and natural waters: Anal. Chem. Acta, v. 12, p. 162-176.

Ramsay, A.T.S., 1971. Occurrence of biogenic siliceous sediment in the Atlantic Ocean: Nature, v. 233, p. 115-117.

Rex, R.W., 1969. X-ray Mineralogy Studies-Leg 1. In Ewing, W.M., Worzel, J.L., et al., Initial Reports of the Deep Sea Drilling Project, Volume 1: Washington (U.S. Government Printing Office), p. 354-368.

Schlanger, S.O. and Douglas, R.G., 1974. Pelagic ooze-chalklimestone transition and its implications for marine stratigraphy. In Hsu, K. and Jenkyns, H.C. (Eds.), Pelagic sediments: on land and under the sea. Spec. Pub. No. 1, Int. Assoc. Sedimentol., p. 117-148.

Sclater, J.G., Anderson, R.N., and Bell, M.L., 1971. Elevation of ridges and evolution of the Central Eastern Pacific: J. Geophys. Res., v. 76, p. 7888-7915.

Siever, R., 1962 . Silica solubility, $0^{\circ}-200^{\circ} \mathrm{C}$, and the diagenesis of siliceous sediments: J. Geol., v. 70, p. 127-150.

Smith, J.V. and Stenstrom, R.C., 1965. Electron-excited luminescence as a petrologic tool: J. Geol., v. 73, p. 627635 .

van Andel, Tj. H., 1974. Cenozoic migration of the Pacific plate, northward shift of the axis of deposition and paleobathymetry of the Central Equatorial Pacific: Geology, v. 2, p. 507-510.

Winterer, E.L., 1973. Sedimentary facies and plate tectonics of Equatorial Pacific: Am. Assoc. Petrol. Geol. Bull., v. 57, p. 265-282.

Wise, S.W., Buie, B.F., and Weaver, F.M., 1972. Chemically precipitated sedimentary cristobalite and the origin of chert: Ecolog. Geol. Helv., v. 65, p. 157-163. 


\section{PLATE 1}

Site 305

Figure 1

Figure 2

Figure 3

Figure 5

Figure 6

Figure 7

Figure 8
17-3 (152 m: Maestrichtian). Massive gray chert from a foraminiferal nannofossil ooze.

21-6 (195 m: Maestrichtian/Campanian). Massive brown chert with conchoidal fracture from a nannofossil ooze.

21-6. Photomicrograph of Figure 2 showing finegrained chalcedony, rare radiolarian ghosts, replaced foraminiferal test and calcite echinoid spine (Tylocidaris sp.). Crossed nicols.

17-3. Photomicrograph of Figure 1 showing a patch (burrow?) containing radiolarians, now coated or replaced by opaque material. Polarized light.

17-3. Crossed nicols.

35, CC (327 m: Turonian/Cenomanian). Gray calcareous porcellanite as coating and inclusions in brown chert.

36-1 (328 m: Turonian/Cenomanian). Euhedral pyrite crystal growing in cavity in gray chert. White calcareous porcellanite lines cavities and forms inclusions.

57, CC (541 m: Albian/Aptian). Chert, mottled gray and brown, in sharp contact with white calcareous porcellanite. 
PLATE 1
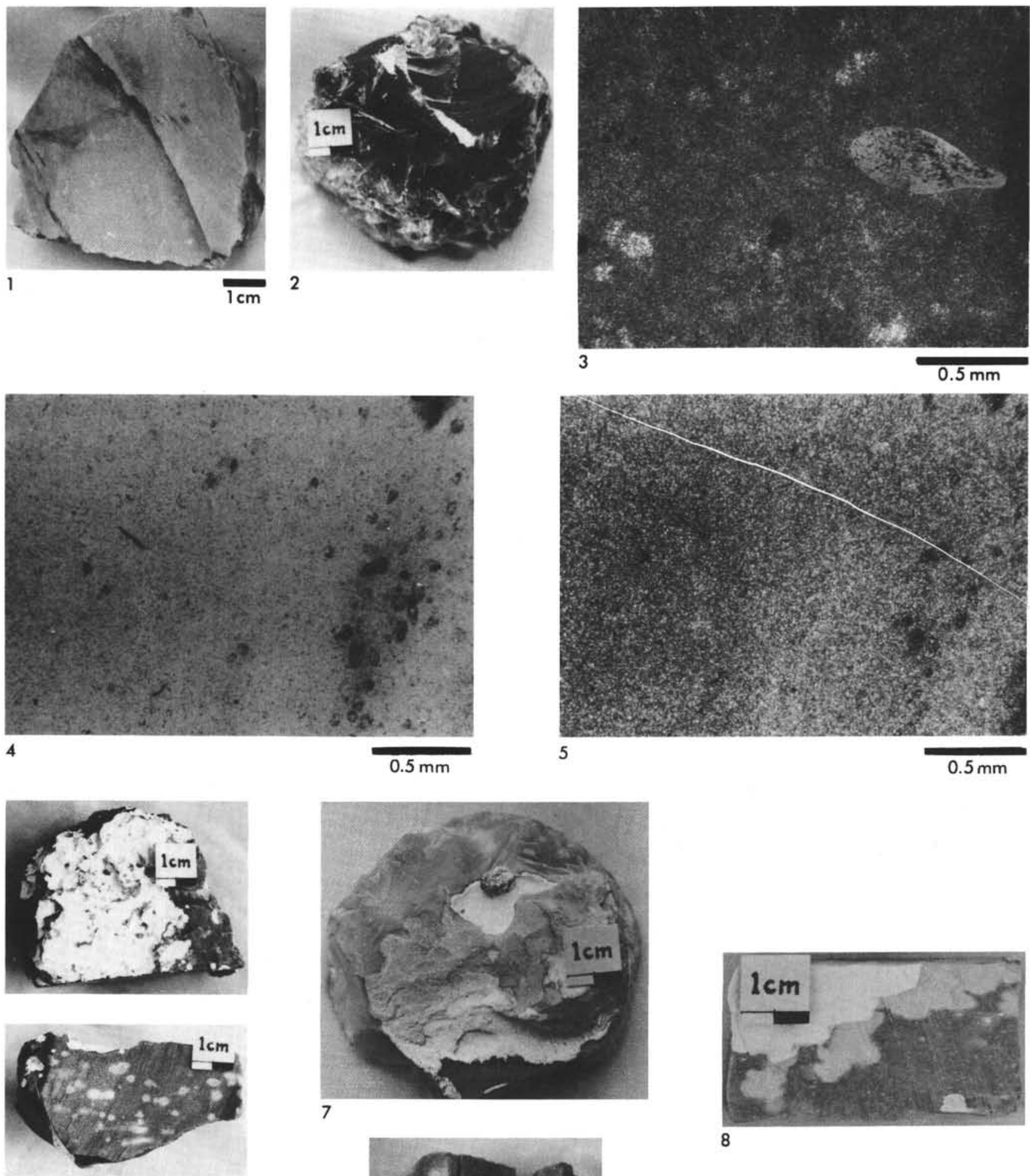

6

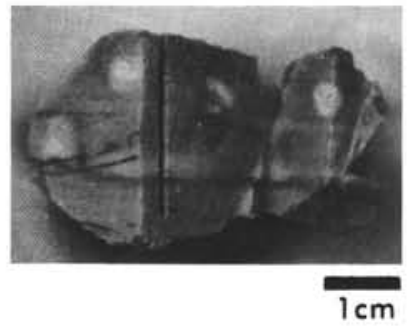




\section{PLATE 2}

\section{Site 305}

Figure 1

36-1 (see Plate 1, Figure 7). Photomicrograph. Inclusion of porcellanite (dark) in chert. Porcellanite is opal-CT and calcite, with chalcedony in foraminiferal chambers. Foraminiferal tests in chalcedonic chert are still calcite in some cases. Irregular calcite crystals (20 to $50 \mu \mathrm{m}$ ) also occur in the chert. Opaque material is common. Polarized light.

Figure 2

Figure 3

Figure 4

Figure 5

Figure 6

\section{6-1. Crossed nicols.}

56-1 (522 m: Albian/Aptian). Photomicrograph. Chalcedonic chert with replaced foraminifera and some calcite crystals (20 to $100 \mu \mathrm{m})$. Vein shows at least two generations of chalcedony. Crossed nicols.

56-1. Photomicrograph of chalcedony vein containing chert fragment. Crossed nicols.

57, CC (see Plate 1, Figure 8). Photomicrograph. Relic opal-CT spheres now replaced by chalcedony lining the wall of a test. Polarized light.

57, CC. Crossed nicols. 
PLATE 2
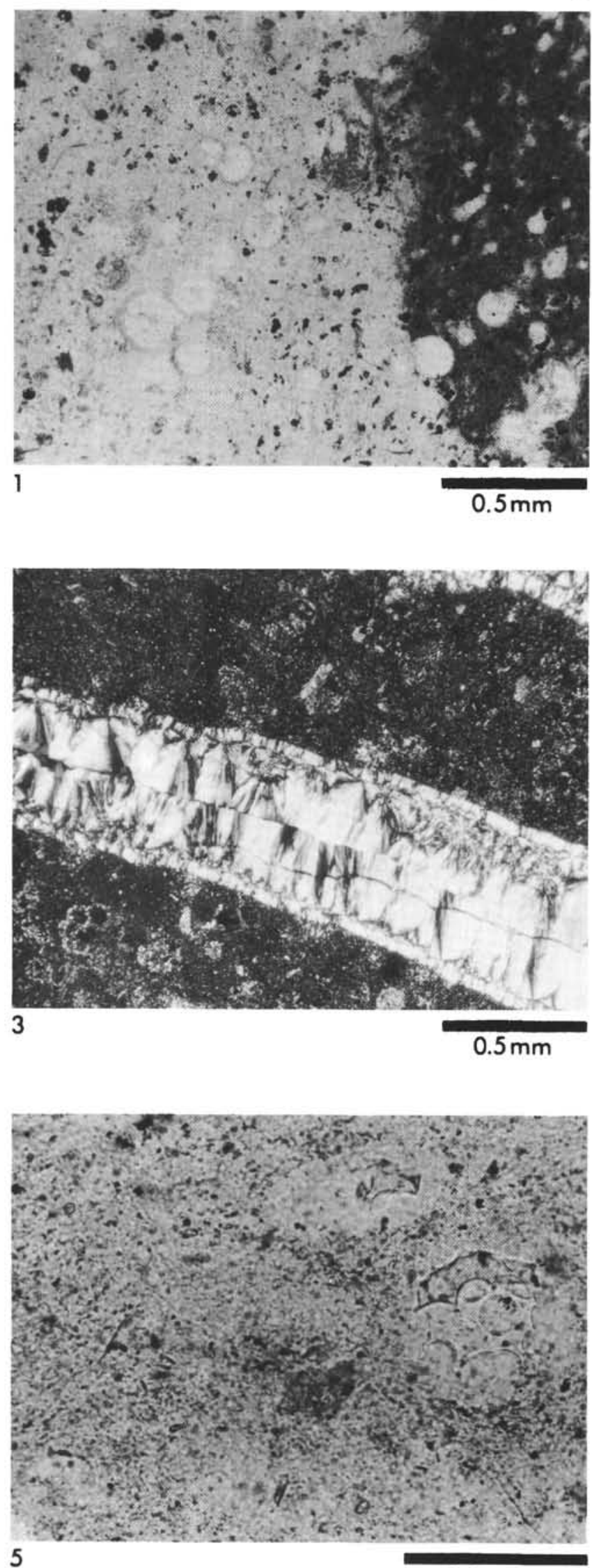

$0.1 \mathrm{~mm}$
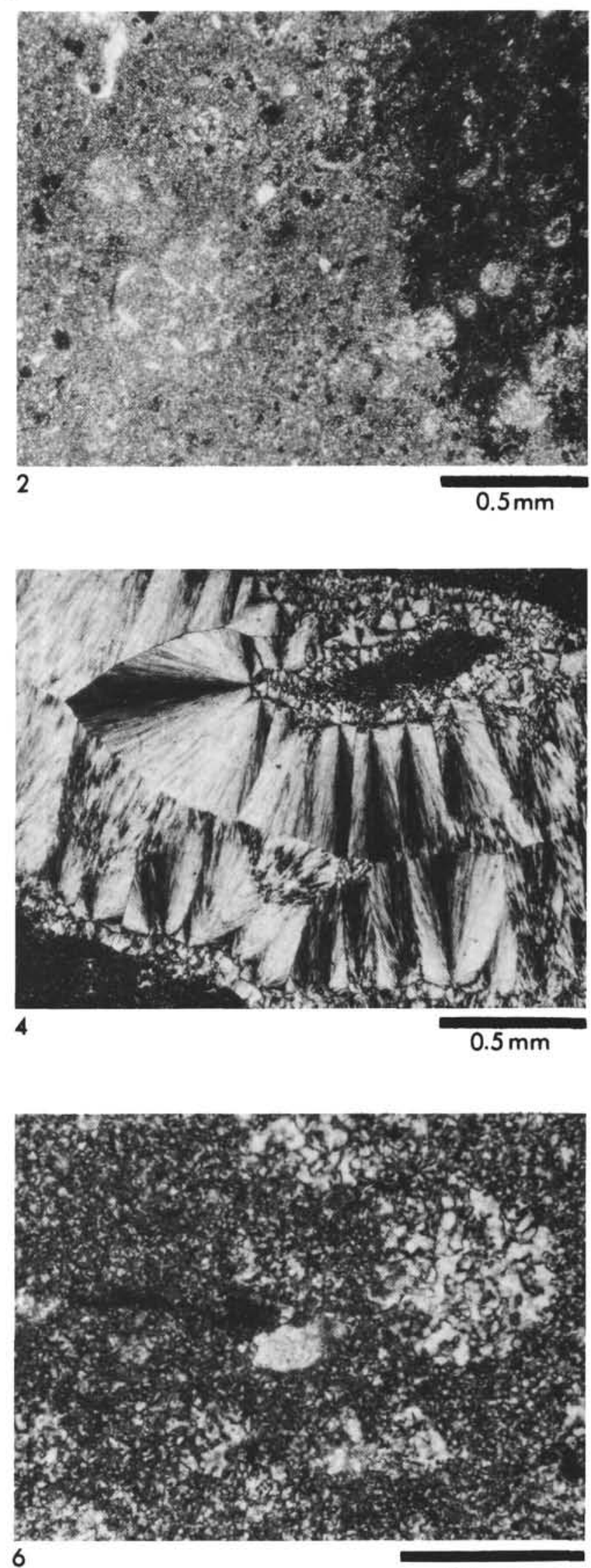

$0.1 \mathrm{~mm}$ 


\section{PLATE 3}

Site 305

Figure 1

58, CC (551 m: Aptian/Barremian). White homogeneous calcareous porcellanite in sharp contact with pale brown calcareous porcellanite with ripple structures. Both have quartz as the silica phase.

Figure 258, CC. Radiograph of Figure 1. A similar pattern of wavy bedding can be seen in the white porcellanite. It is accentuated in the upper porcellanite by more complete silicification at the base of each layer.

Figure 3 63-1 (589 m: Aptian/Barremian). Brown chert as a nodule in white calcareous porcellanite.

Figure 4 63-1. Radiograph of Figure 3. Nodule is elongate along bedding. Laminae continue from porcellanite into nodule; they are not depressed around nodule.

Figure $5 \quad 61-1$ (570 m: Aptian/Barremian). Laminae in gray calcareous porcellanite are depressed around an early formed chalcedony vein.

Figure 6 58, CC. Photomicrograph of Figure 1. Base of porcellanite is more silicified (chalcedony) and has sharp contact with underlying, more calcareous porcellanite. Polarized light.

Figure 7

58, CC. Crossed nicols.

Figure 8 61-1. SEM photo of Figure 5. Chalcedony vein in porous calcareous porcellanite showing irregular contact between vein and porcellanite. Calcareous coccoliths and chalcedony occur in the porcellanite. 
PLATE 3
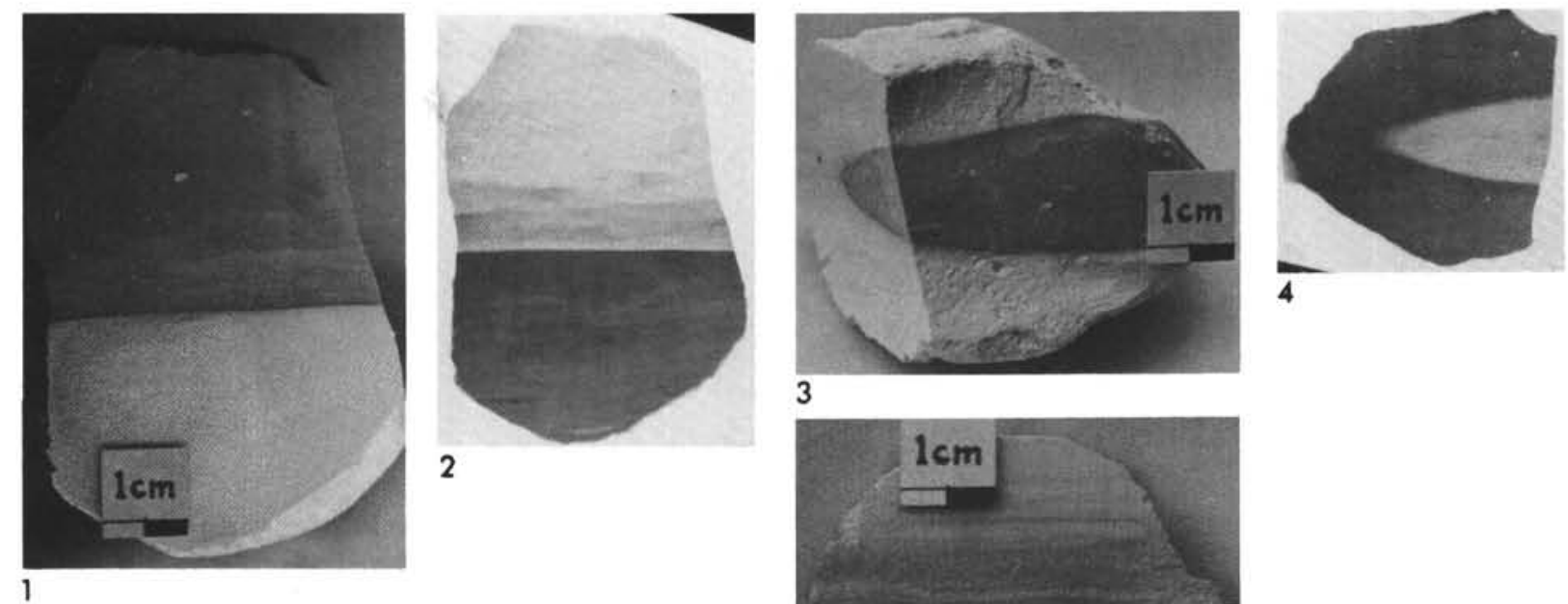

1
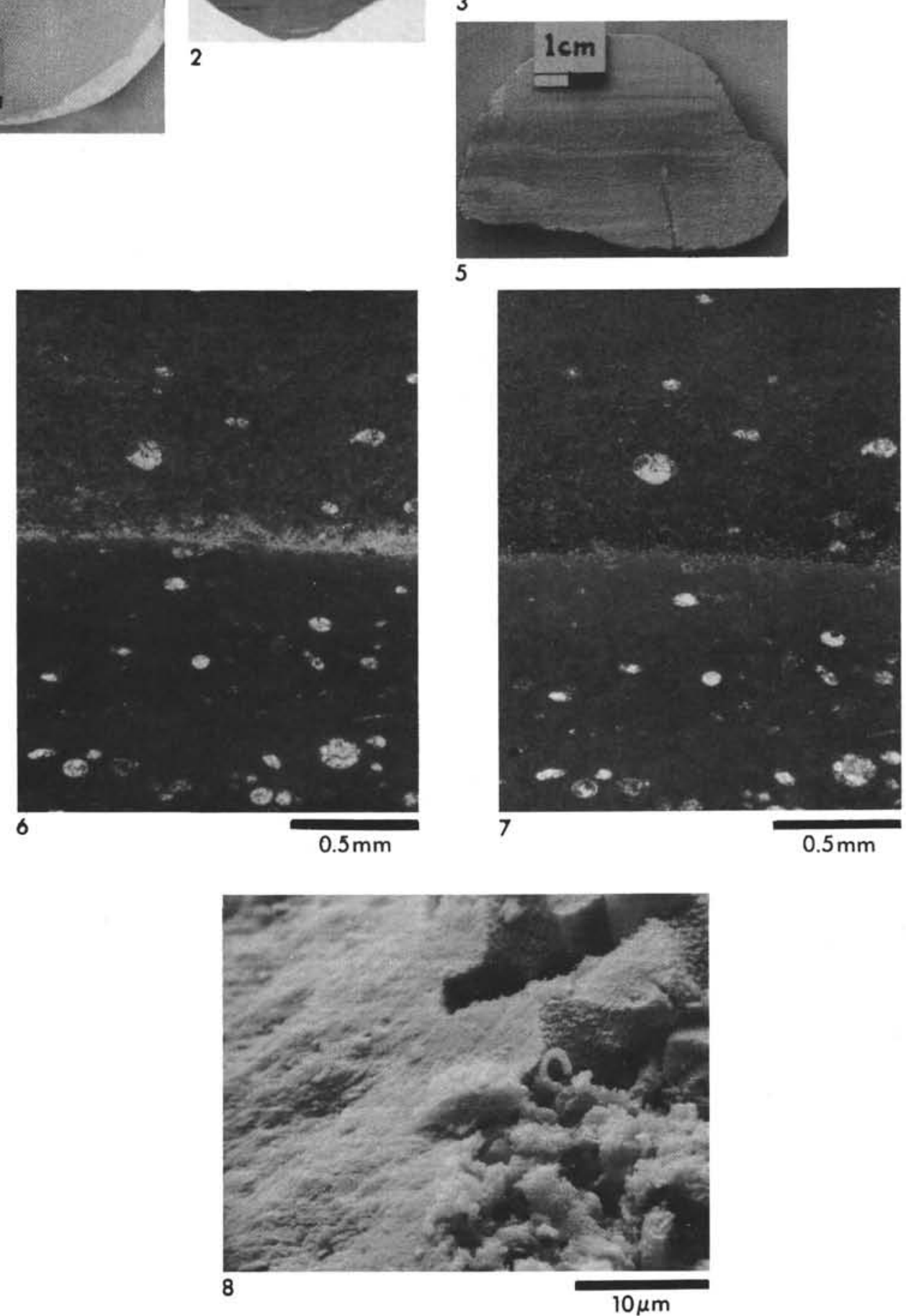
PLATE 4

Site 305

Figure 1

Figure 2

Figure 3

Figure 4

Figure 5

Figure 6

Figure 7
65-1 (608 m: Aptian/Barremian). Gray laminated porcellanite, opal-CT rich.

65-1. Photomicrograph of Figure 1. Radiolarians filled by opal-CT and chalcedony in a groundmass of massive opal-CT. Polarized light.

65-1. SEM photo of Figure 1. Spheres of bladed opal-CT partly fill radiolarian tests. Massive, porous opal-CT groundmass.

65-1. SEM photo of opal-CT groundmass.

65-1. SEM photo of a radiolarian (Nassellaria). Opal-A test has been replaced by opal-CT.

65-1. SEM photo of bladed opal-CT forming spheres.

65-1. SEM photo of opal-CT radiolarian test. 
PLATE 4
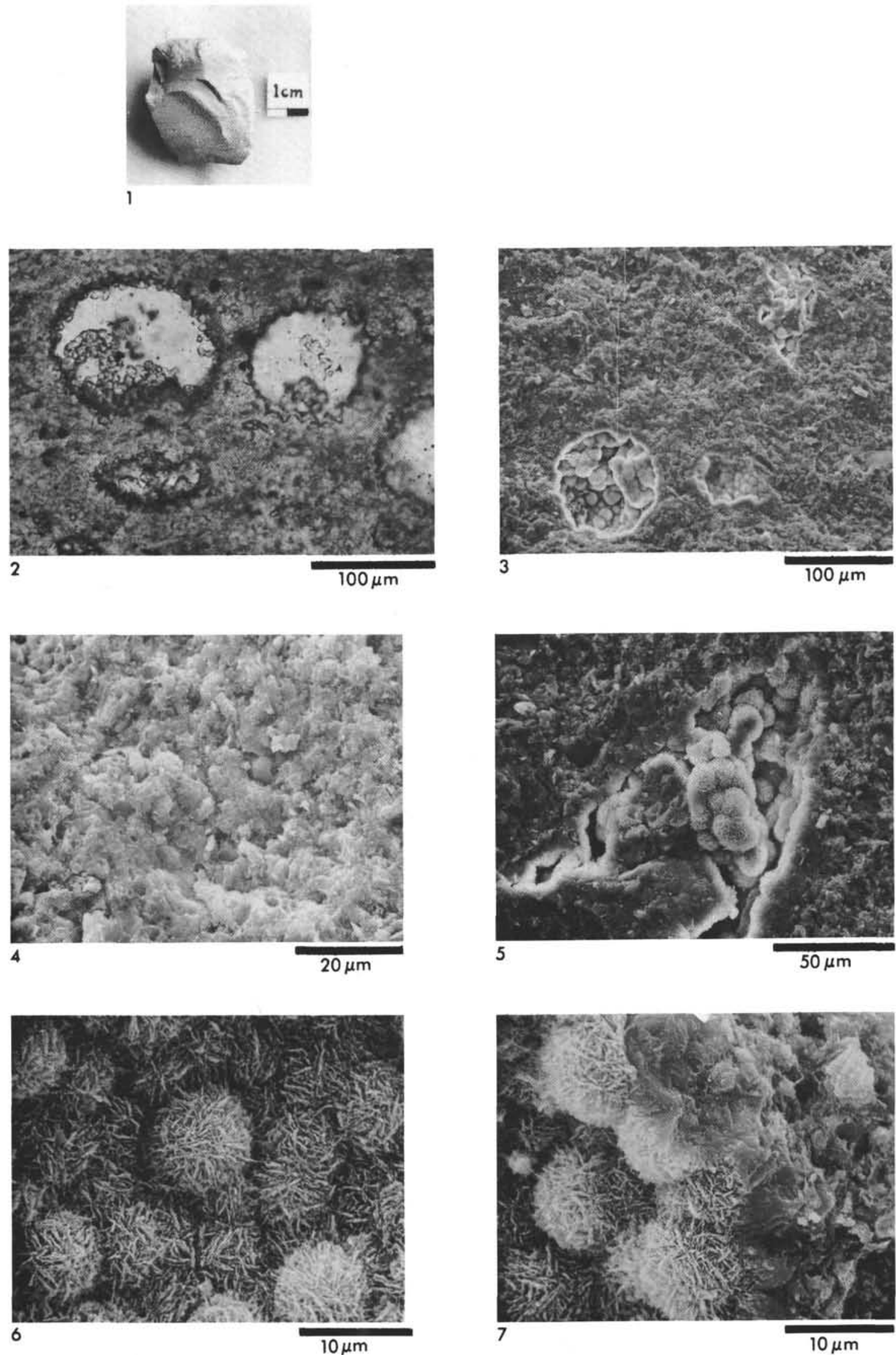


\section{PLATE 5}

Site 306

Figure 1

Figure 2

Figure 3

Figure 4

Figure 5

Figure 6

Figure 7

Figure 8

Figure 9

Figure 10
3, CC ( $28 \mathrm{~m}$ : Cenomanian/Albian). Nodule of gray-green chert bounded by a $5-\mathrm{mm}$ zone of opalCT porcellanite in carbonate.

12, CC (198 m: Aptian/Barremian). Gray chert with $1 \mathrm{~mm}$ zone of opal-CT overlain by calcareous porcellanite.

6-1 (76 m: Albian/Aptian). Nodular chert in gray calcareous porcellanite.

9-2 (134 m: Aptian/Barremian). Gray calcareous porcellanite. Opal-CT rich.

21, CC (291 m: Valanginian). Nodular chert in gray calcareous porcellanite.

8-1 (113 m: Albian/Aptian). Gray calcareous opal-CT rich porcellanite with lens of brown chert.

3, CC. Photomicrograph of Figure 1. Contact between partly silicified carbonate and opal-CT zone. Radiolarians and foraminifera are chalcedony filled. Crossed nicols.

3, CC. Photomicrograph of Figure 1. Sharp contact between opal-CT zone and chert. Crossed nicols.

12, CC. Photomicrograph of Figure 2. Opal-CT zone exists between quartzose chert and calcareous opal-CT porcellanite. Chalcedonyfilled radiolarians common in porcellanite and chert. Polarized light.

12, CC. Crossed nicols. Opal-CT is almost isotropic. 
PLATE 5
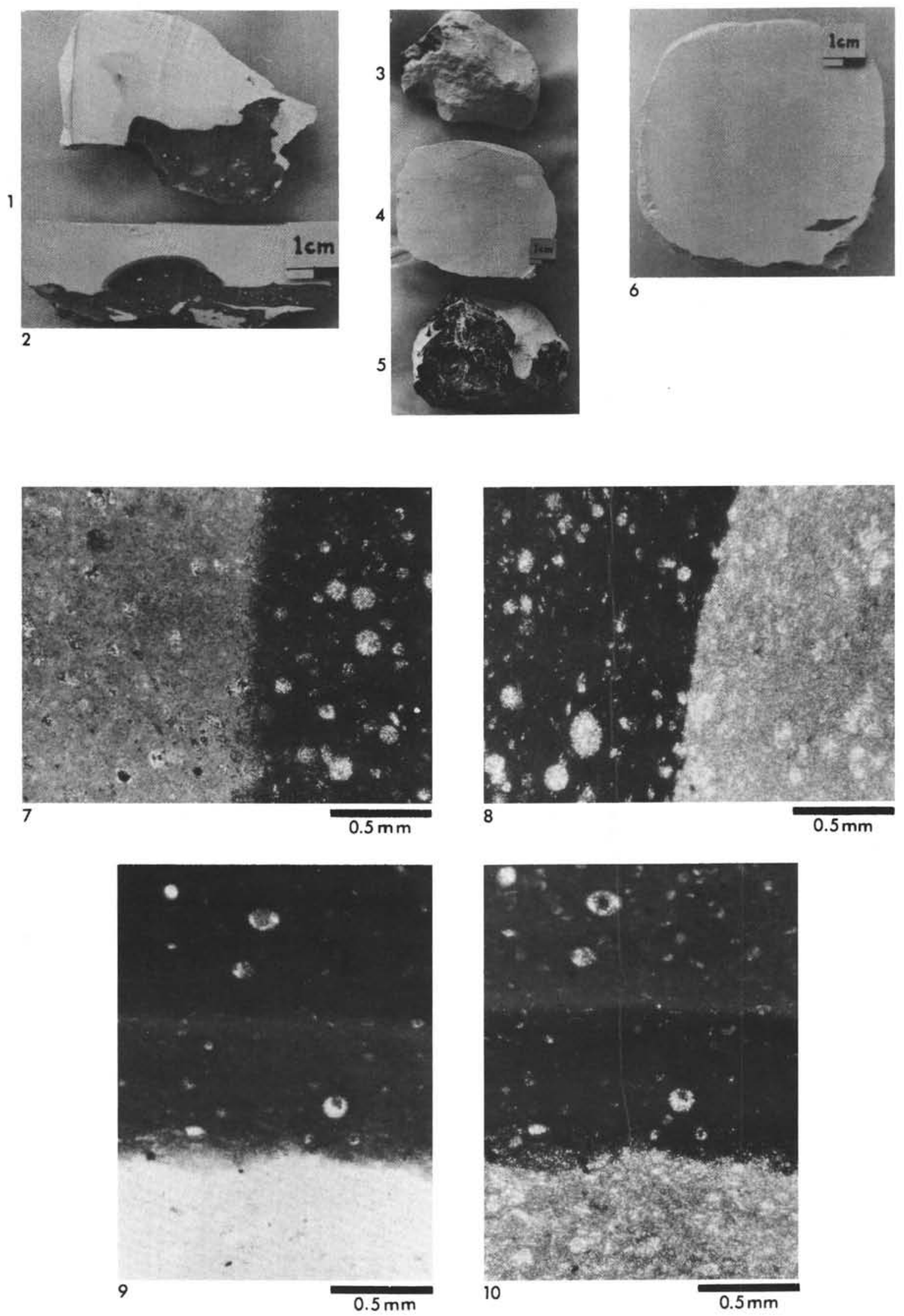


\section{PLATE 6}

Site 306

Figure 1 10-1 (151 m: Aptian/Barremian). Calcareous porcellanite laminae compacted around a chert nodule.

Figure 235 , CC (412 m: Valanginian/Berriasian). Inclusions of calcareous porcellanite in bedded chert.

Figure $340, \mathrm{CC}$ (459 m: Valanginian/Berriasian). Sharp contact between bedded porcellanite and chert.

Figure $4 \quad 42, \mathrm{CC}(475 \mathrm{~m}$ : Berriasian). Chalcedony and calcite vein in mottled chert.

Figure 5 10-1. Photomicrograph of Figure 1. Densely packed radiolarians in chert nodule. Fewer radiolarians (chalcedony filled) and more opal-CT in porcellanite (bottom left). Polarized light.

Figure 6

10-1. Crossed nicols.

Figure $735, \mathrm{CC}$. Photomicrograph of Figure 2. Contact between calcareous porcellanite and chert. Chert contains some irregular calcite crystals ( 20 to 50 $\mu \mathrm{m})$ also present in the porcellanite. Radiolarians are common in both. Polarized light.

Figure 8 35, CC. Crossed nicols. 
PLATE 6

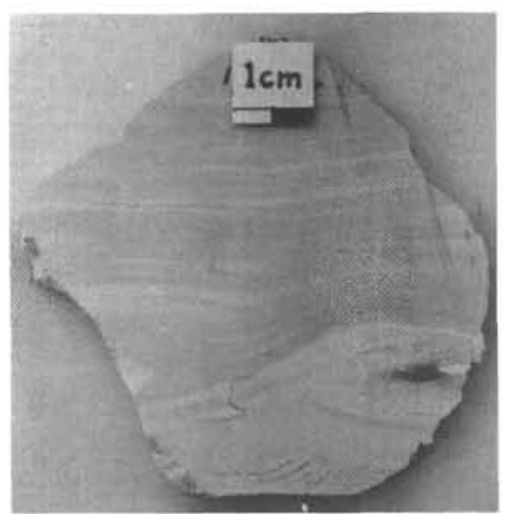

1

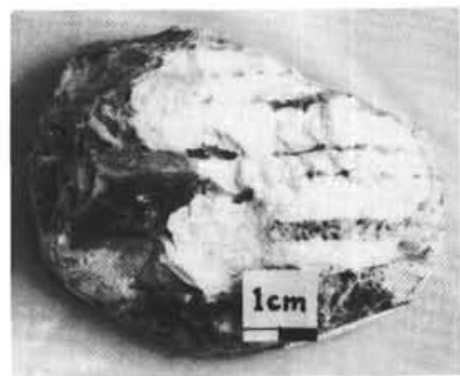

2

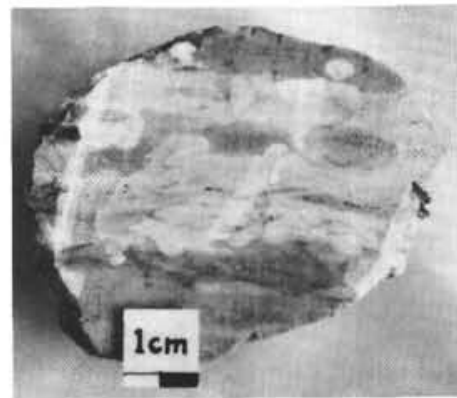

2

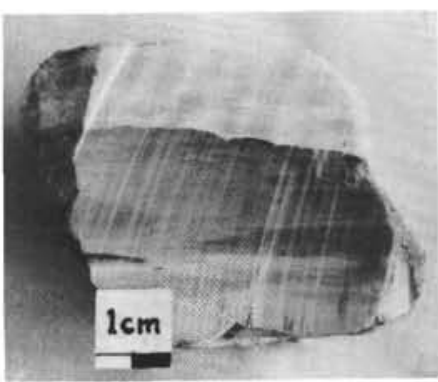

3

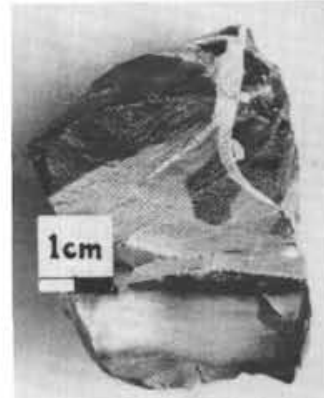

4
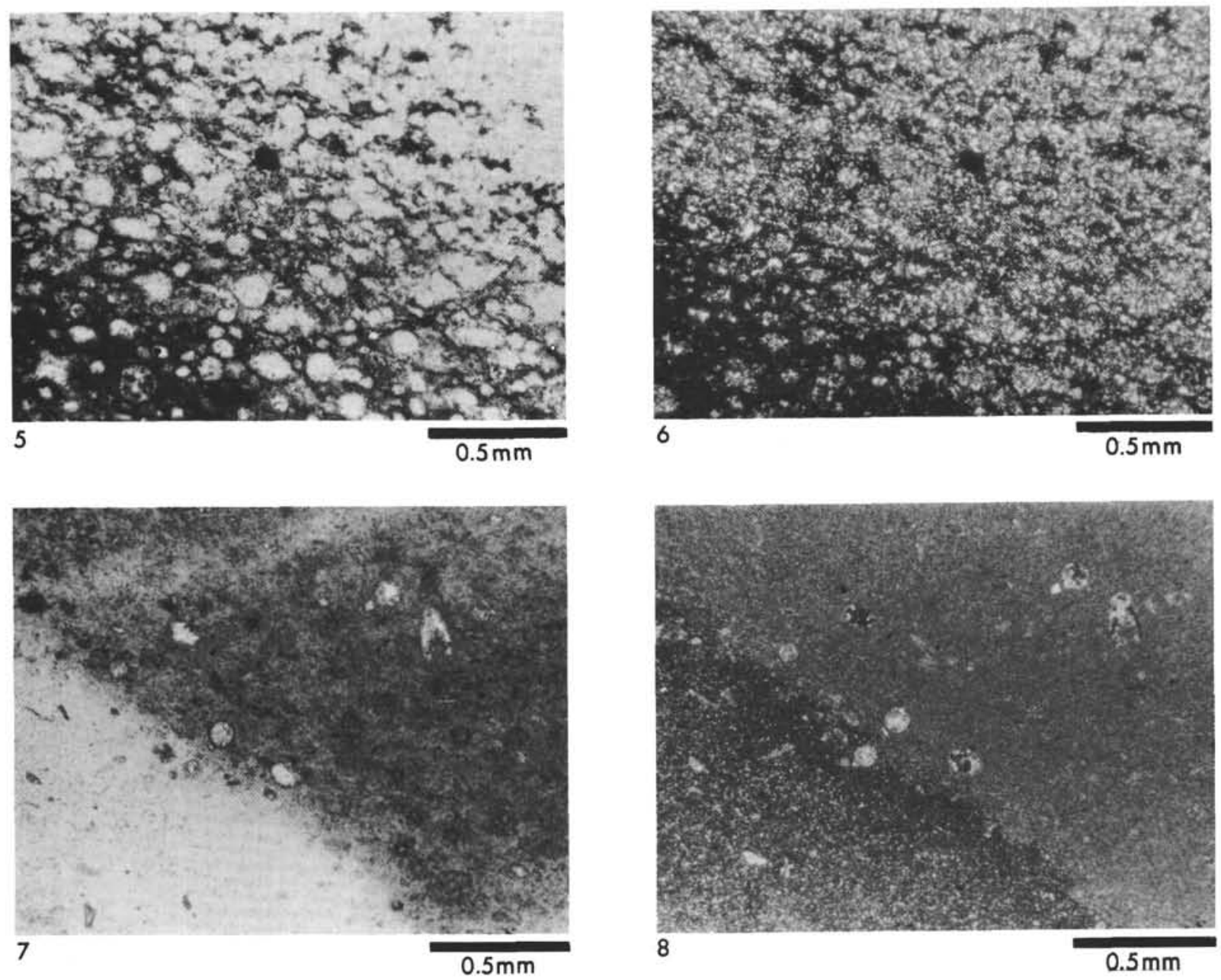


\section{PLATE 7}

Figure 1

Figure 3

Figure 4

Figure 5

Figure 6
306-42, CC (see Plate 6, Figure 4). Photomicrograph. Chalcedony vein in radiolarian chert. Upper vein is more recent and contains calcite and microquartz. Crossed nicols.

306-40, CC (see Plate 6, Figure 3). Photomicrograph. Carbonate vein has sharp boundaries in radiolarian chert and more difuse boundaries in porcellanite. Crossed nicols.

306-42, CC (see Plate 6, Figure 4). Photomicrograph. Chalcedony vein in radiolarian chert cut by younger calcite vein. Polarized light.

306-42, CC. Crossed nicols.

305-65, CC (617 m: Aptian/Barremian). Photomicrograph. The detailed radiolarian test has been replaced by calcite. The test is filled with chalcedony. Groundmass is calcareous porcellanite (opal-CT). Polarized light.

305-65, CC. Crossed nicols. 
PLATE 7

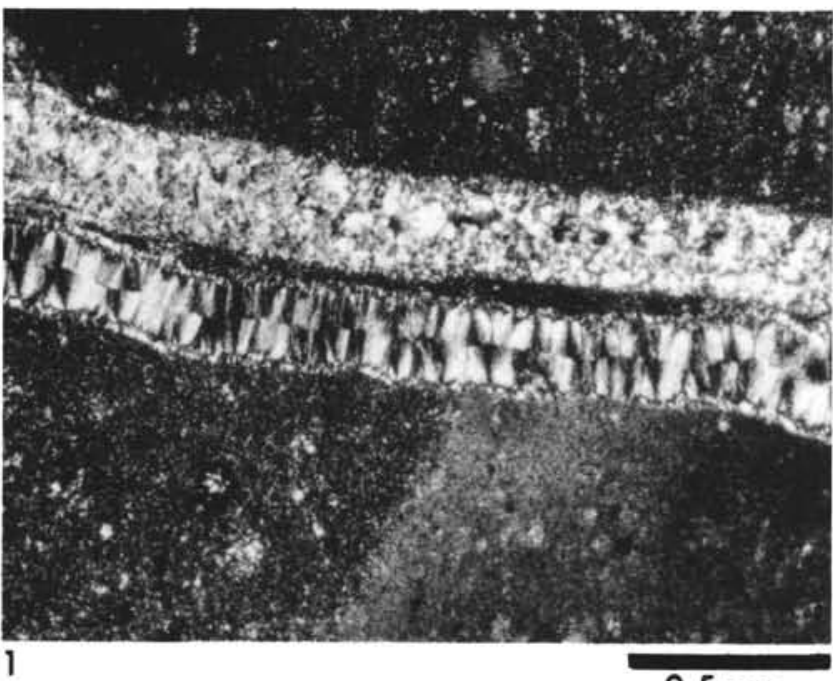

$0.5 \mathrm{~mm}$

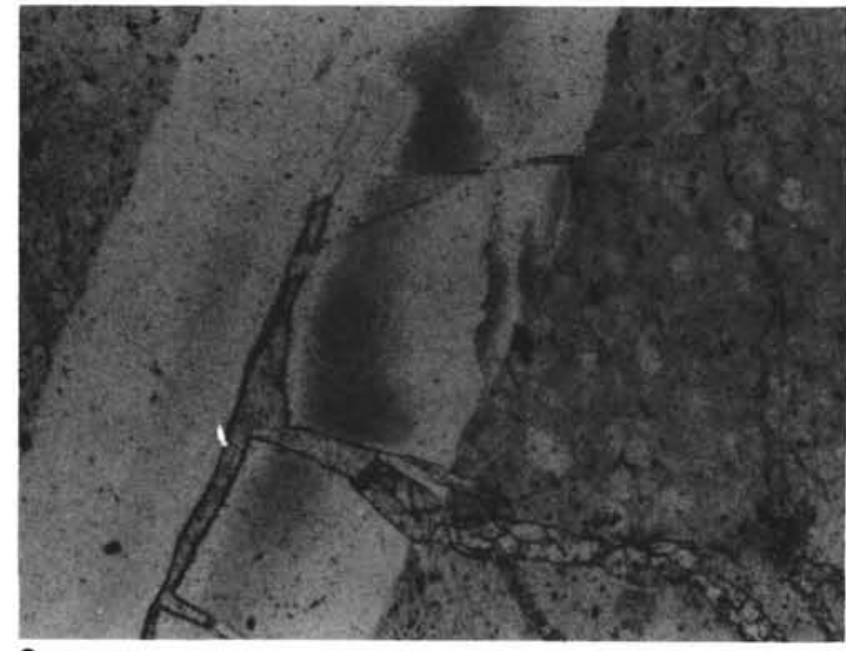

3

$0.5 \mathrm{~mm}$

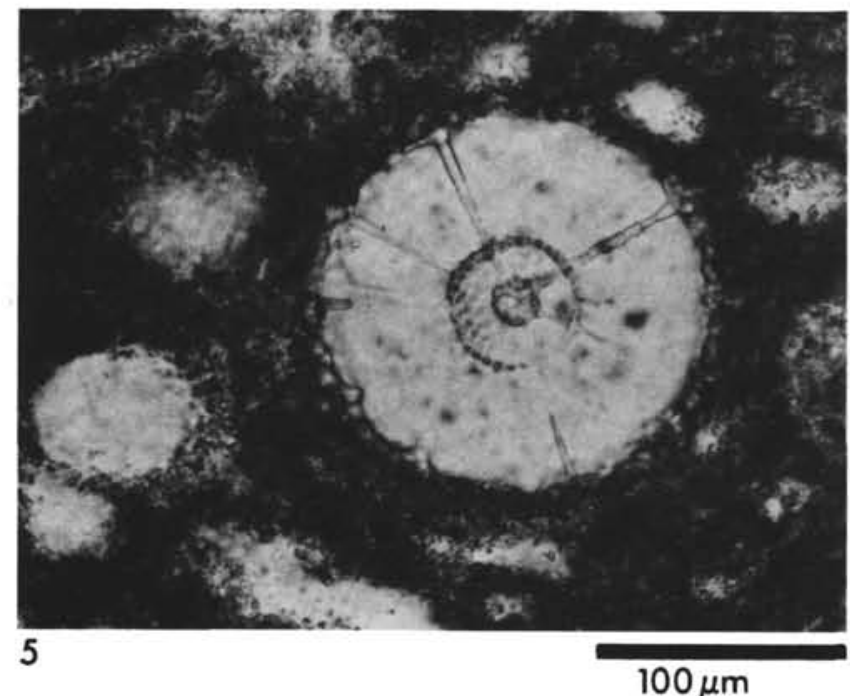

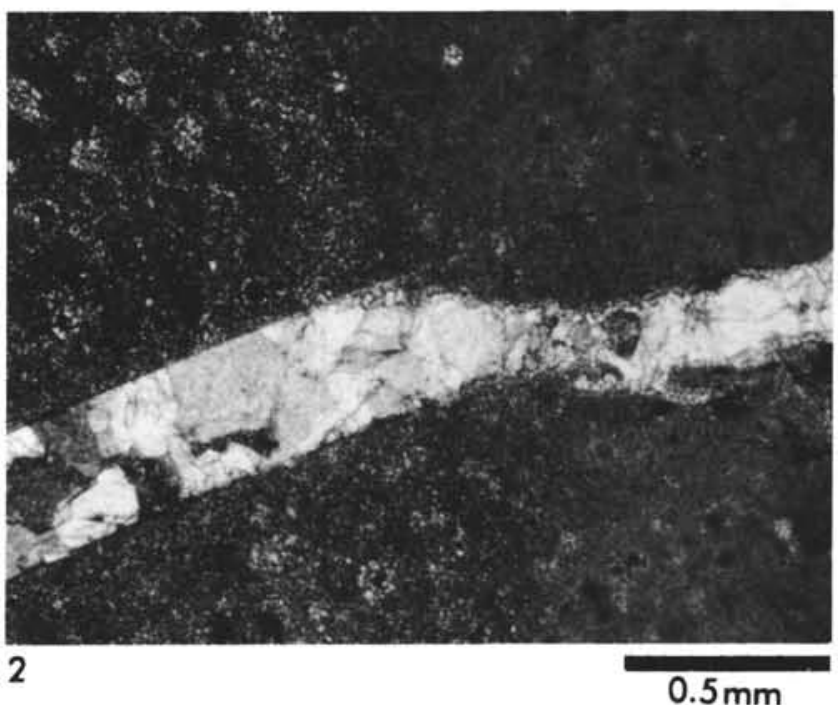
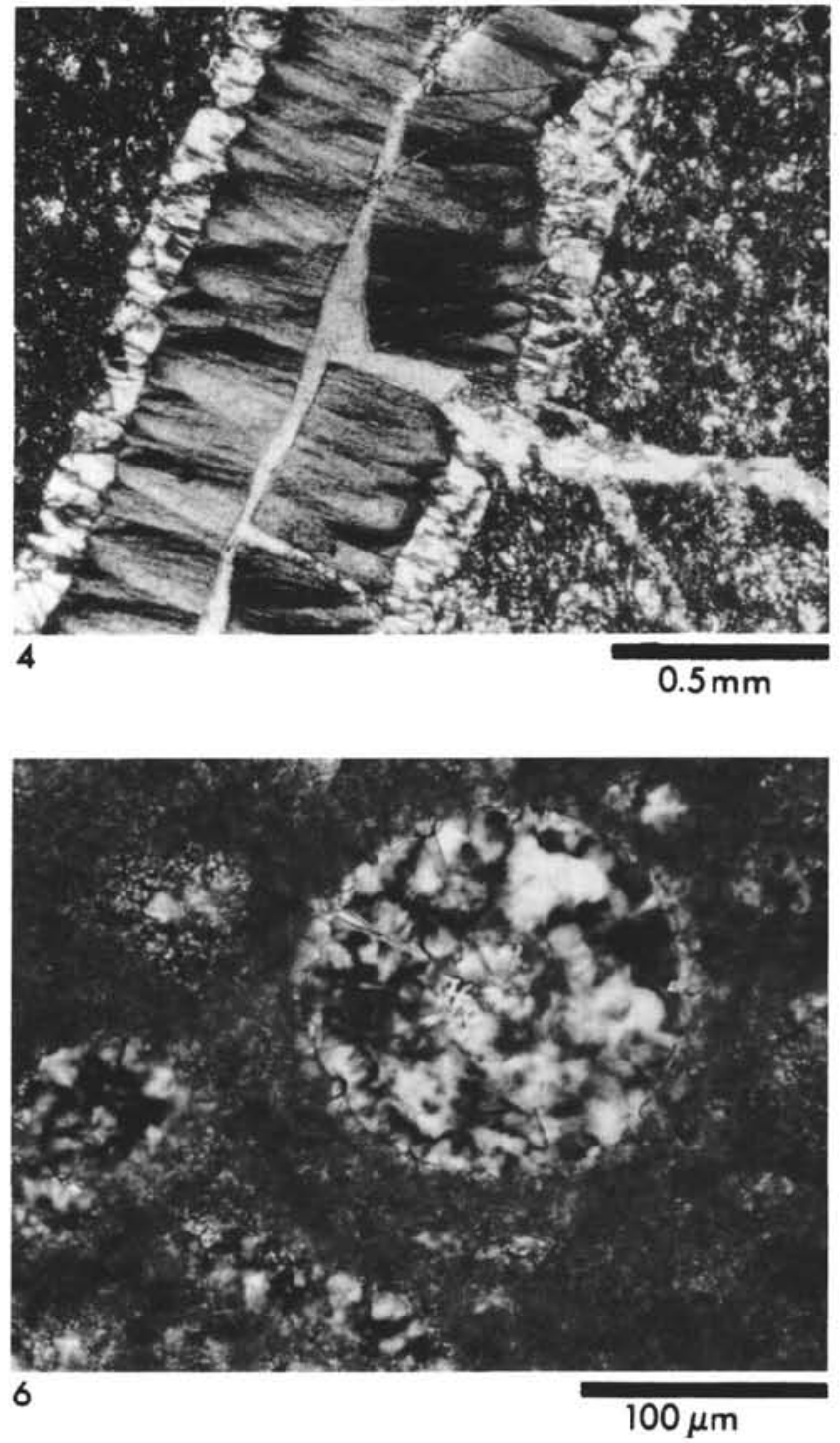


\section{PLATE 8}

Figure $1306-12$, CC (see Plate 5). SEM photo. Sphere of chalcedony filling foraminiferal chamber whereas walls are still calcite. Coccoliths in groundmass are calcite.

Figure 2 306-12, CC. Element map of Figure 1 showing distribution of silicon. Groundmass is mostly massive opal-CT.

Figure 3 306-35, CC (see Plate 6). SEM photo of calcareous porcellanite. Porous, recrystallized carbonate is partly cemented by chalcedony (arrow).

Figure 4 310A-5, CC (213 m: Santonian/Turonian). Bedded brown chert with thin layer of calcareous porcellanite.

Figure 5 310A-7, CC (232 m: Santonian/Turonian). Typical gray chert.

Figure 6 310A-9, CC (250 m: Santonian/Turonian). Bedded gray chert with some inclusions of white calcareous porcellanite. 


\section{PLATE 8}
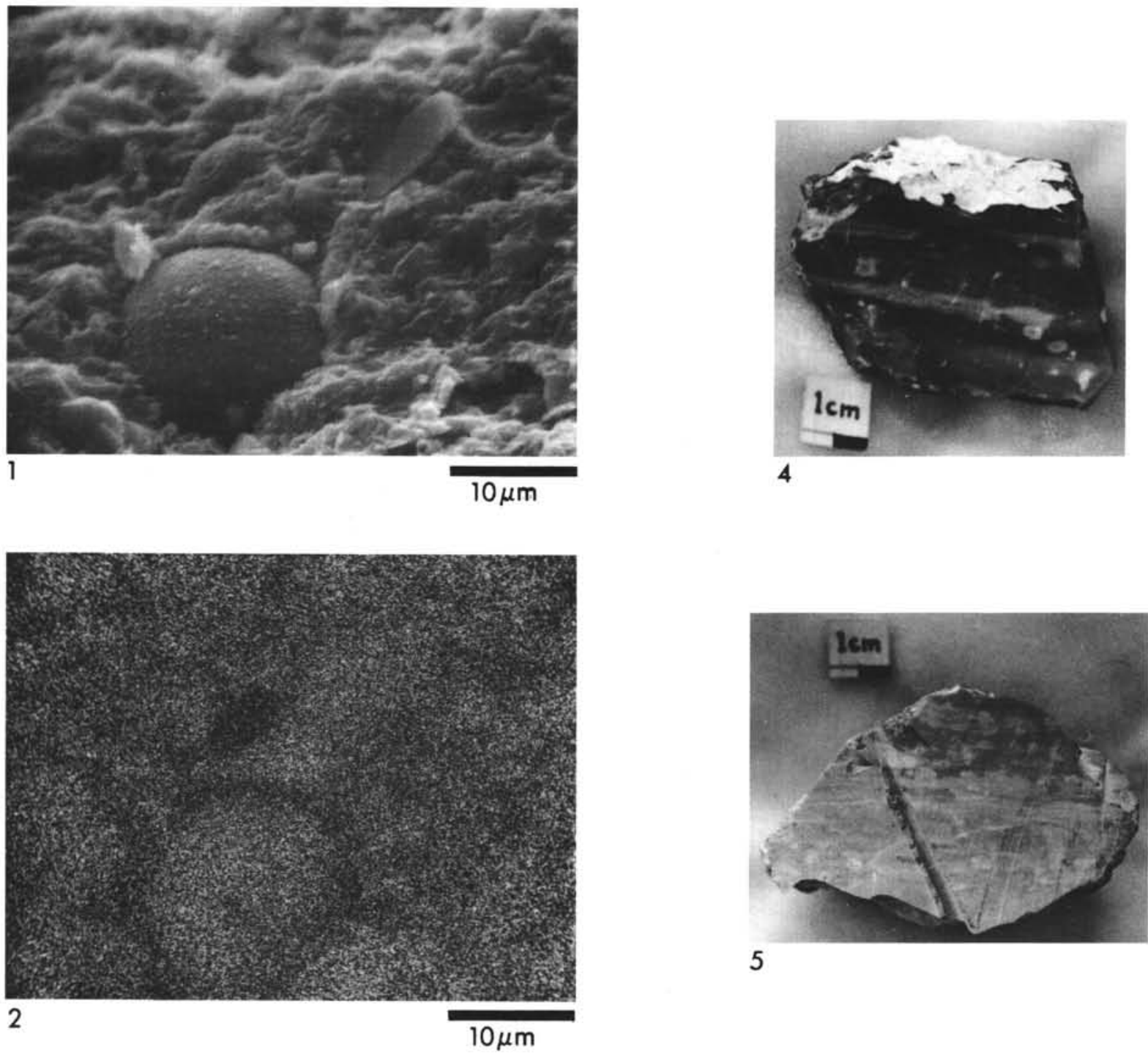

5
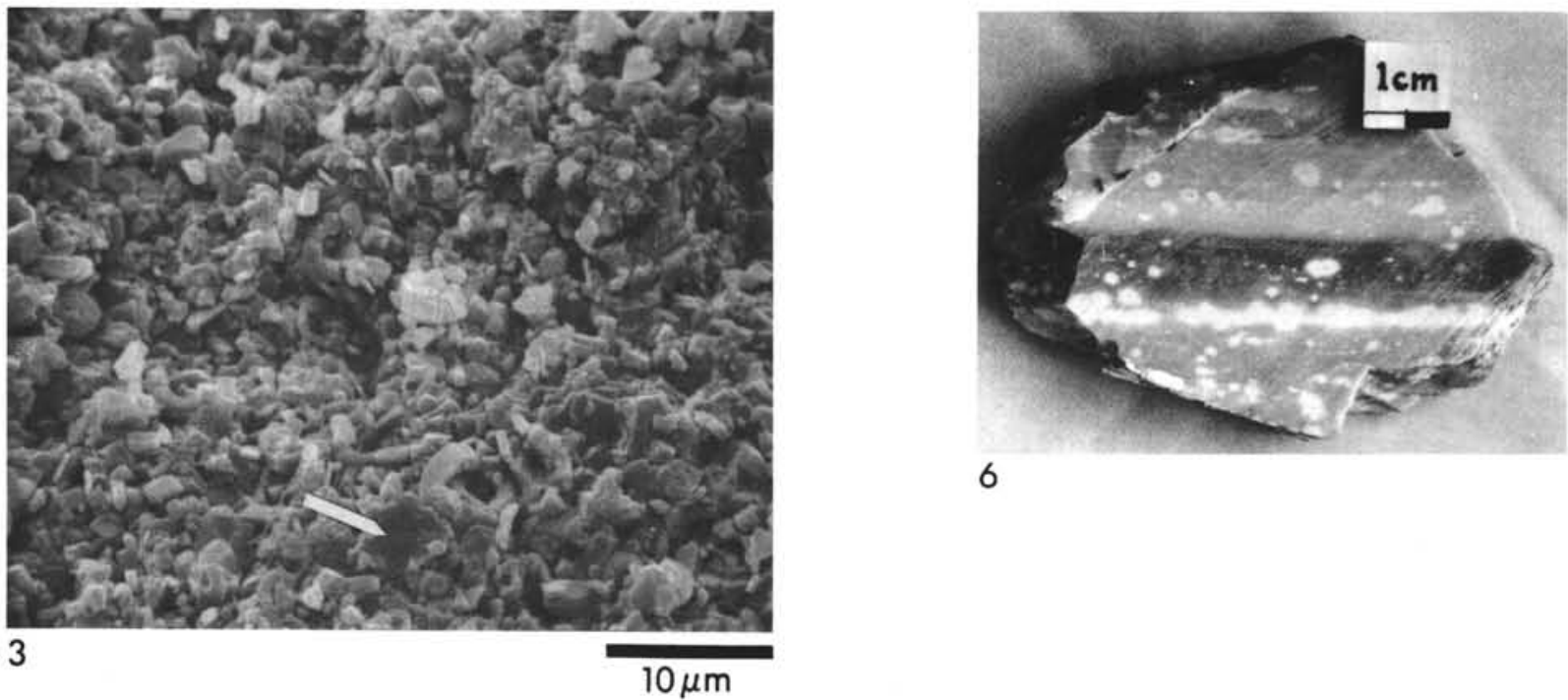

6 


\section{PLATE 9}

Site $310 \mathrm{~A}$

Figure 15 , CC (see Plate 8, Figure 4). Photomicrograph. Radiolarians coated with, or replaced by, opaque material in fine-grained chalcedonic chert. Some rare carbonate. Polarized light.

Figure 25 , CC. Crossed nicols.

Figure 37 , CC (see Plate 8, Figure 5). Photomicrograph. Chert with radiolarians filled with chalcedony. Subhedral calcite grains ( 20 to $30 \mu \mathrm{m}$ ) are common in fine-grained chalcedony groundmass. Polarized light.

Figure $4 \quad 7$, CC. Crossed nicols.

Figure 59 , CC (see Plate 8, Figure 6). Photomicrograph. Chalcedonic chert containing radiolarians and a biserial foraminifer. Foraminiferal test is calcite and chambers are filled with chalcedony. Polarized light.

Figure $6 \quad 9$, CC. Crossed nicols. 
PLATE 9
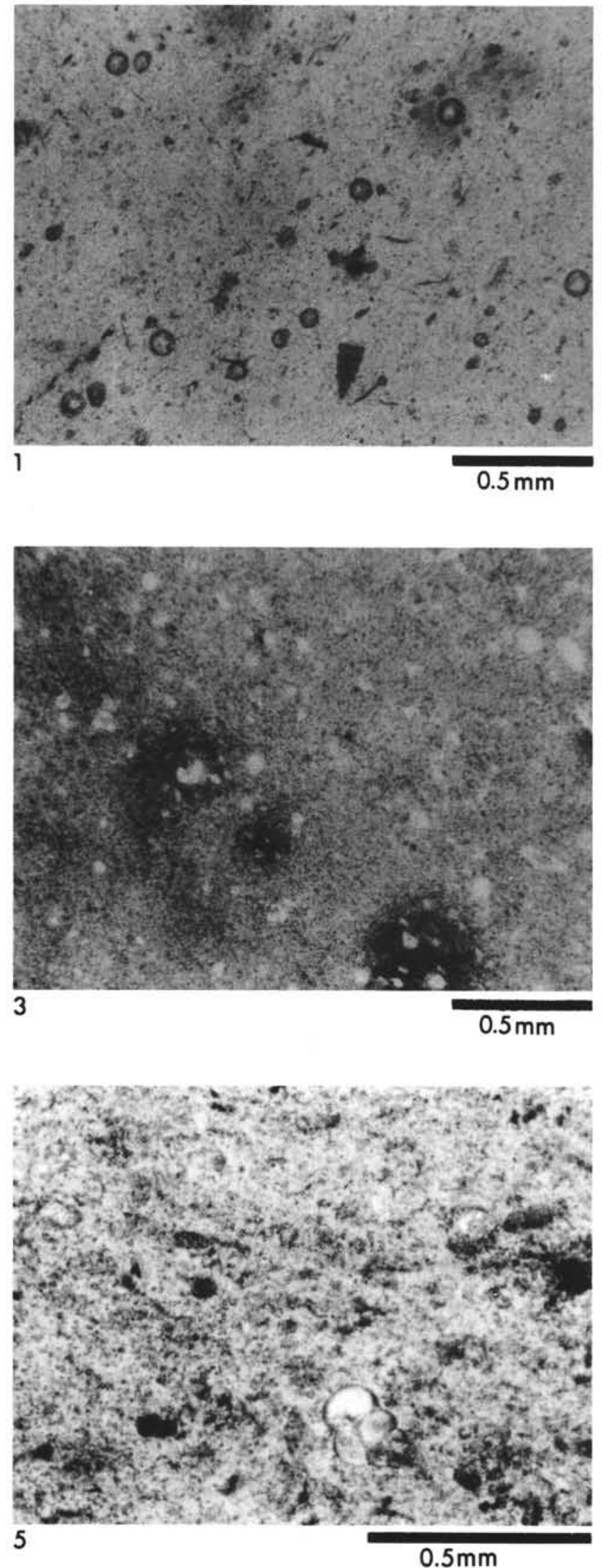
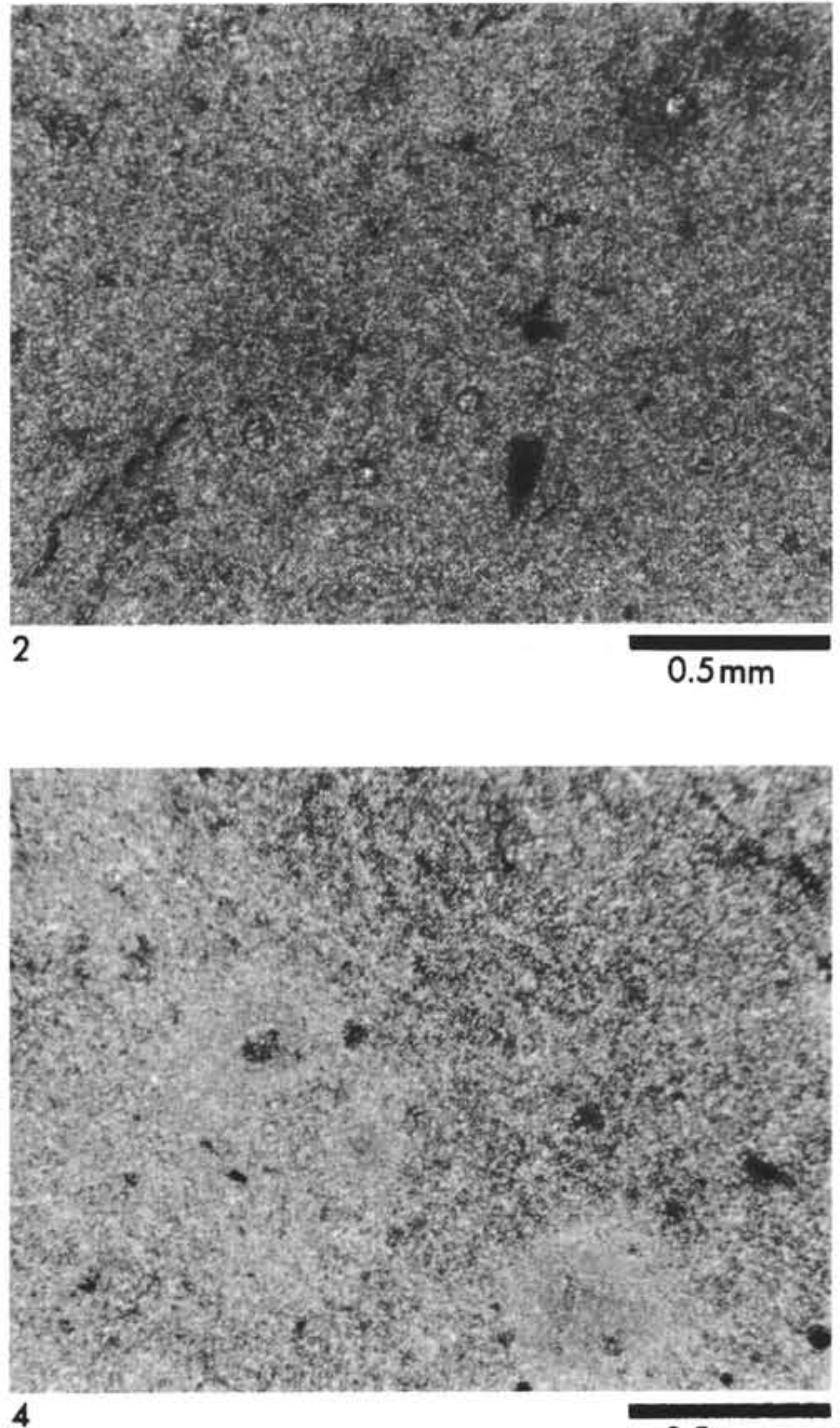

$0.5 \mathrm{~mm}$

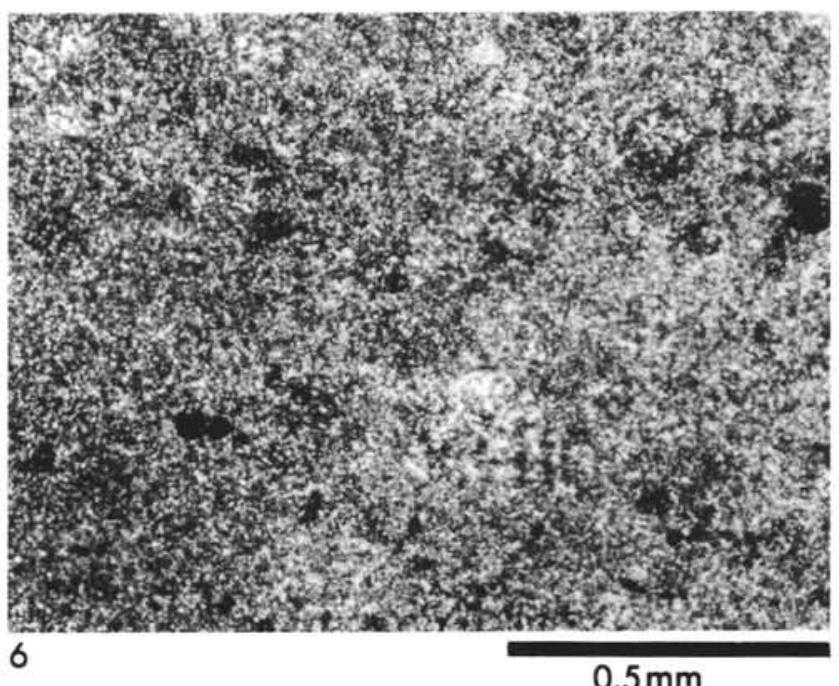




\section{PLATE 10}

Site $310 \mathrm{~A}$

Figure 1

Figure 2

Figure 3

Figure 4

Figure 5

Figure 6

Figure 7

Figure 8

Figure 9
12, CC (278 m: Santonian/Turonian). Calcareous porcellanite with lenses of brown chert parallel to bedding.

12, CC. Photomicrograph of Figure 1. Contact between chalcedonic chert and calcareous porcellanite. Radiolarians are common. Crossed nicols.

13, CC (288 m: Turonian/Cenomanian). Nodule of brown chert in calcareous porcellanite.

13, CC. Radiograph of Figure 3. Some chert attached to the nodule extends along bedding. The porcellanite containing the chert has more radiolarians and is paler than the overlying darker, more calcareous porcellanite.

13, CC. Photomicrograph of Figure 3. Zone of opal-CT between chalcedonic chert and calcareous porcellanite. Chalcedony-filled radiolarians are abundant. Polarized light.

13, CC. Crossed nicols.

17, CC. (334 m: Cenomanian/Albian). Dark gray mottled chert containing a cavity.

17, CC. Photomicrograph of Figure 7. Relic opalCT spheres now converted to chalcedony. Polarized light.

17, CC. Crossed nicols. 
PLATE 10

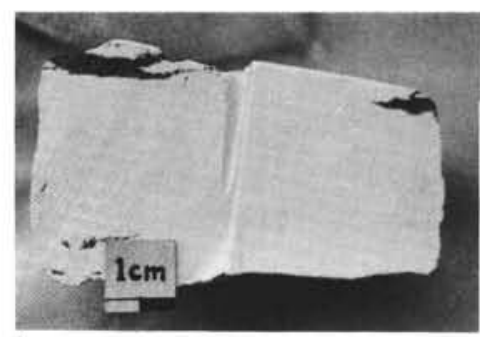

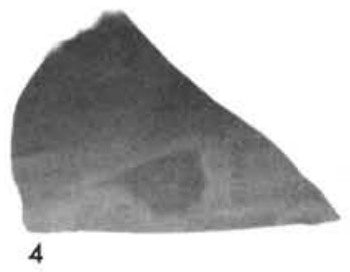

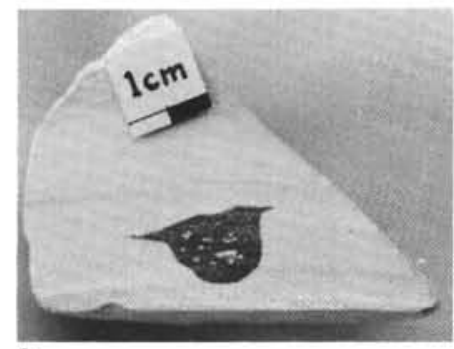

3
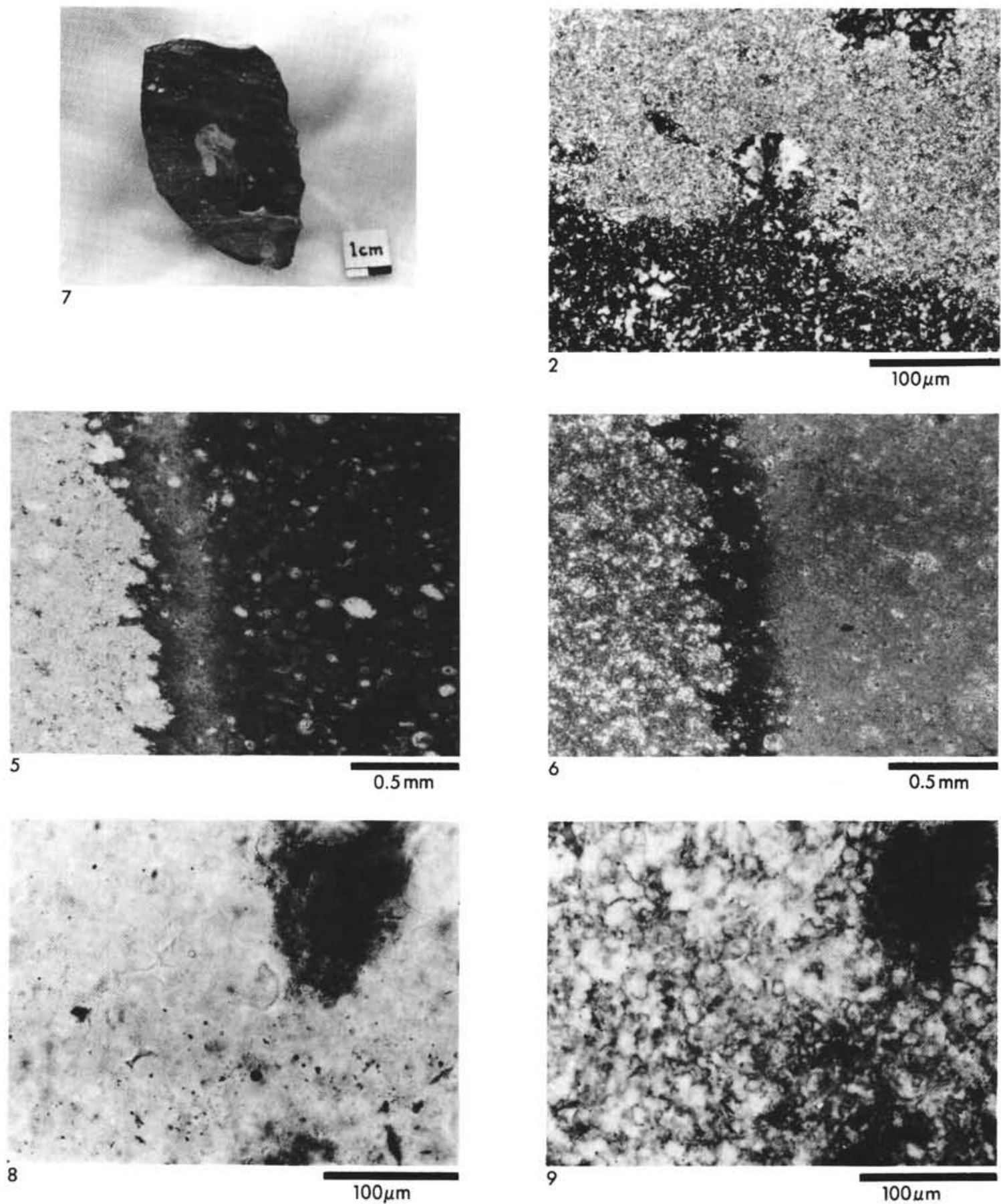


\section{PLATE 11}

Site 313

Figure $1 \quad 5-0(150 \mathrm{~m}$ : late Eocene). Gray bedded chert. Sharp contact with calcareous porcellanite.

Figure $2 \quad 7-3$ (172 m: middle Eocene). Greenish-gray chert enclosing white calcareous porcellanite.

Figure 310 , CC. (196 m: early Eocene). Well-bedded gray chert.

Figure 4 16-5. (250 m: Maestrichtian). Brown chert with irregular contact with calcareous porcellanite (opal-CT). Burrows are preserved in the chert as porcellanite.

Figure 5 5-0. Photomicrograph of Figure 1. Densely packed foraminifera in chert. No calcite remains. Polarized light.

Figure 6 5-0. Photomicrograph of Figure 1. Foraminiferal test is replaced by chalcedony. One chamber is filled with opal-CT and another filled with opalCT and chalcedony. Matrix is both opal-CT and chalcedony. Polarized light.

Figure 7 16-5. Photomicrograph of Figure 4. Burrow in chert is opal-CT and contains radiolarians coated or replaced by opaque material. Only ghosts of radiolarians and foraminifera can be seen in the chalcedonic chert. Polarized light.

Figure $8 \quad 16-5$. Crossed nicols. The chert, with many replaced foraminifera, has a coarse texture compared to the burrow filling. 
PLATE 11

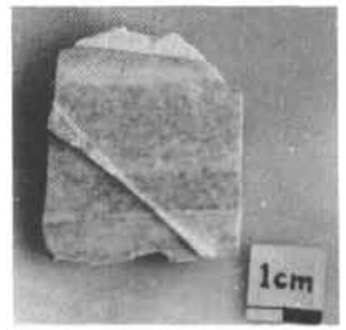

1

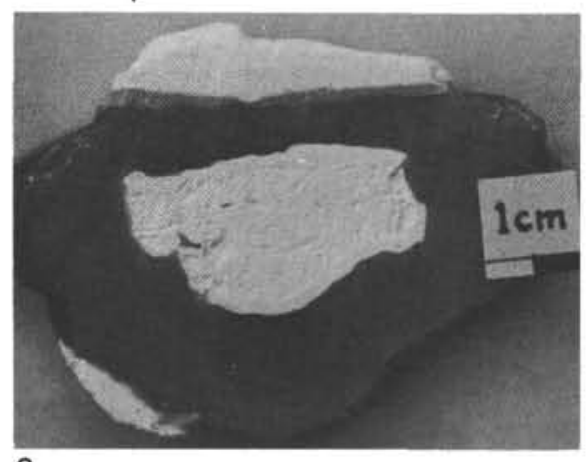

2

3
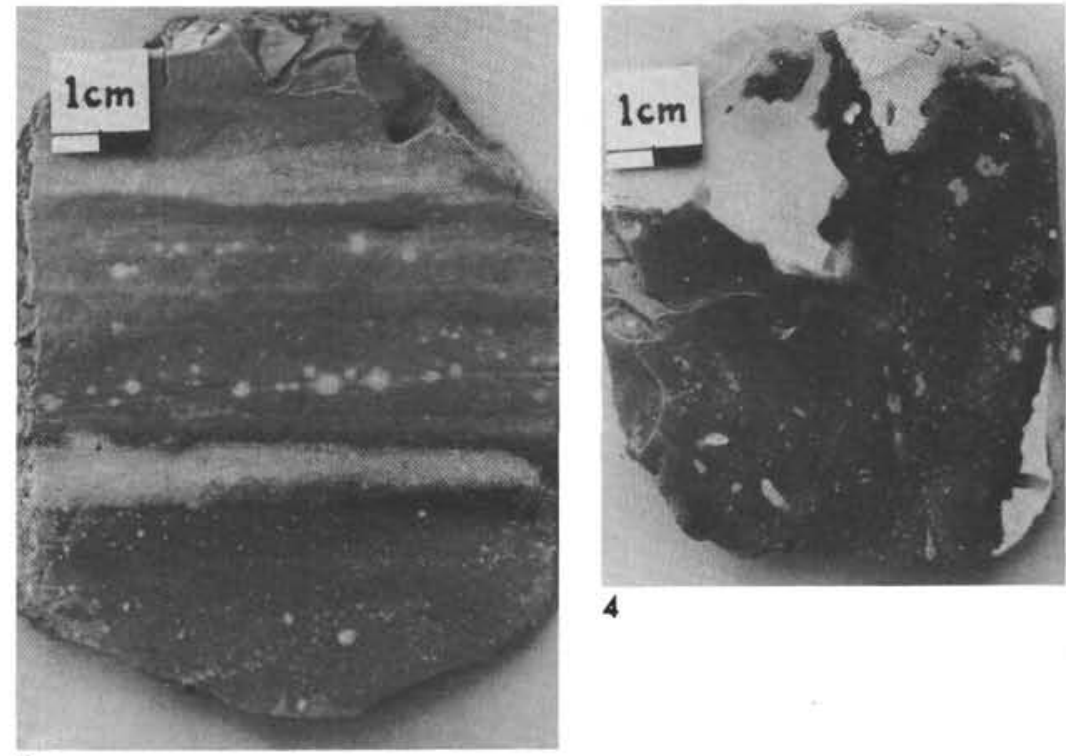
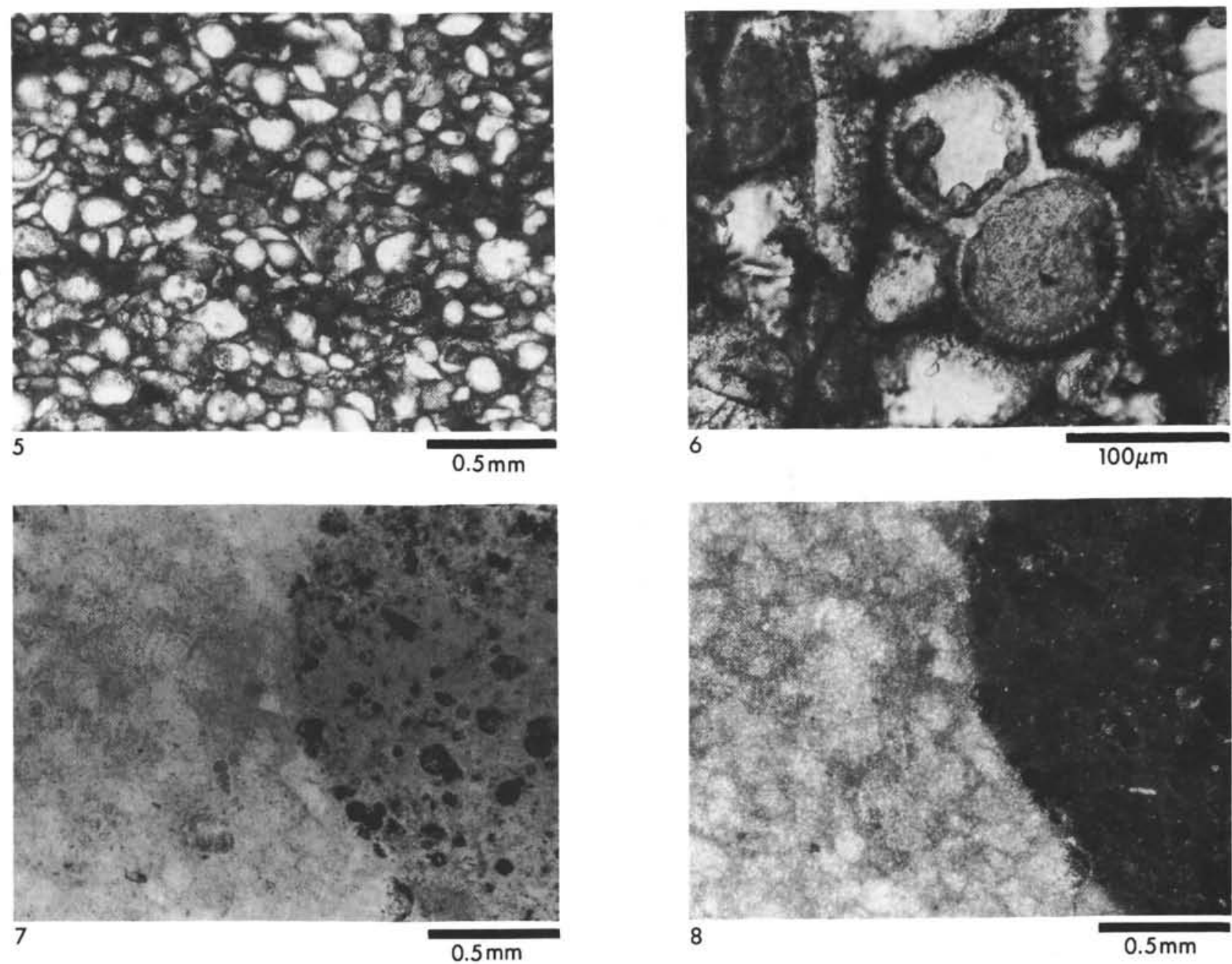


\section{PLATE 12}

\section{Site 313}

Figure $1 \quad 10, \mathrm{CC}$ (see Plate 11, Figure 3). Photomicrograph. Chert containing foraminifera now replaced by silica (chalcedony). The upper layer contains opalCT. Polarized light.

Figure $210, \mathrm{CC}$. Crossed nicols.

Figure 310, CC. Enlargement of Figure 1. Relic opal-CT spheres in foraminiferal chamber in chert are now fine-grained chalcedony. Polarized light.

Figure 4 10, CC. Crossed nicols.

Figure 5 22-1 (397 m: Maestrichtian/Campanian). Gray calcareous porcellanite. Silicification is more extensive near bedding plane. Facing is unknown.

Figure $638-1$ (542 m: Campanian). Blebs of irregular shaped porcellanite in a calcareous porcellanite.

Figure $7 \quad 38-2$. Silicification follows bedding in a calcareous porcellanite.

Figure $8 \quad 38-2$. Radiograph of Figure 7. Silicified layers are light and more calcareous layers are dark. 
PLATE 12
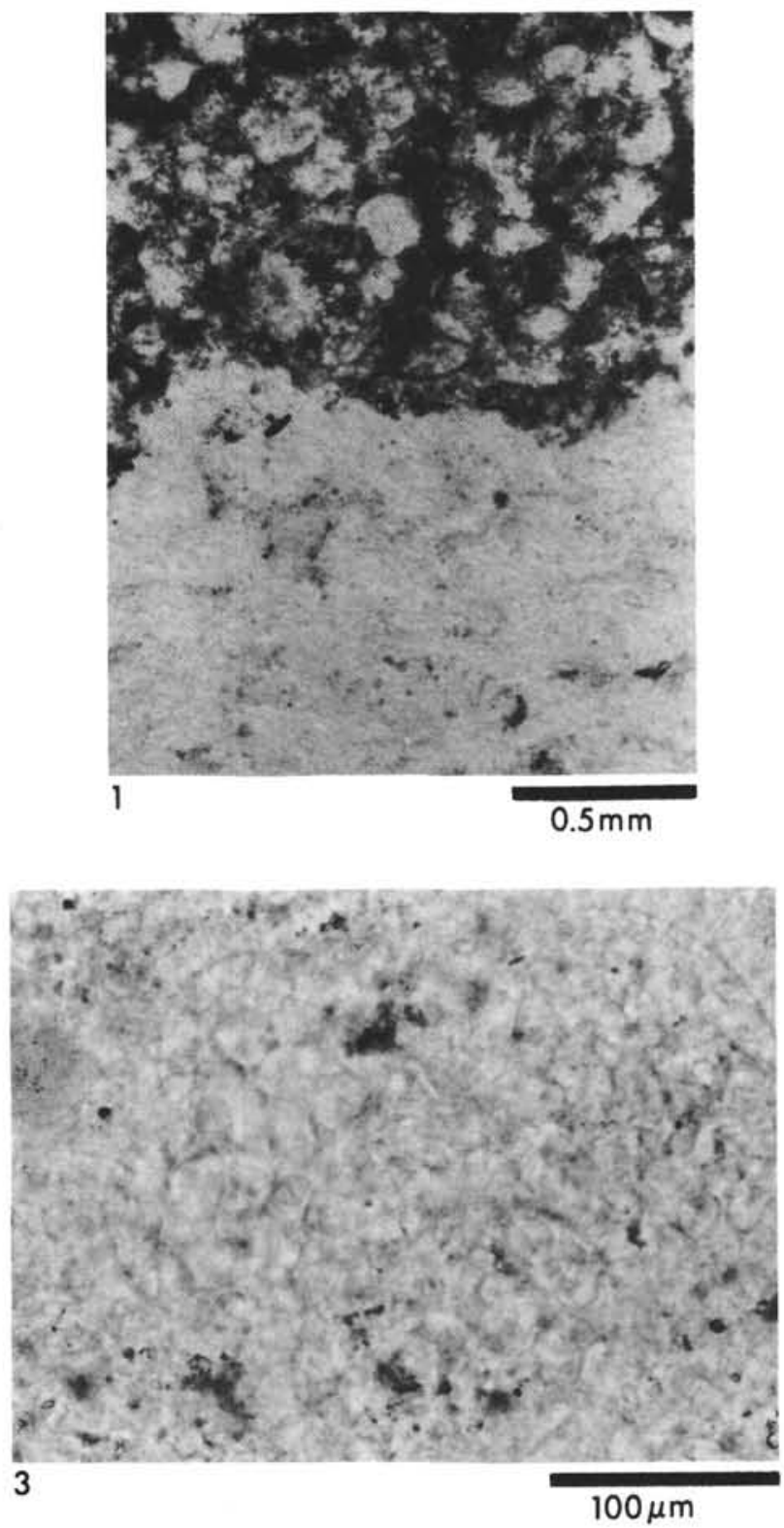
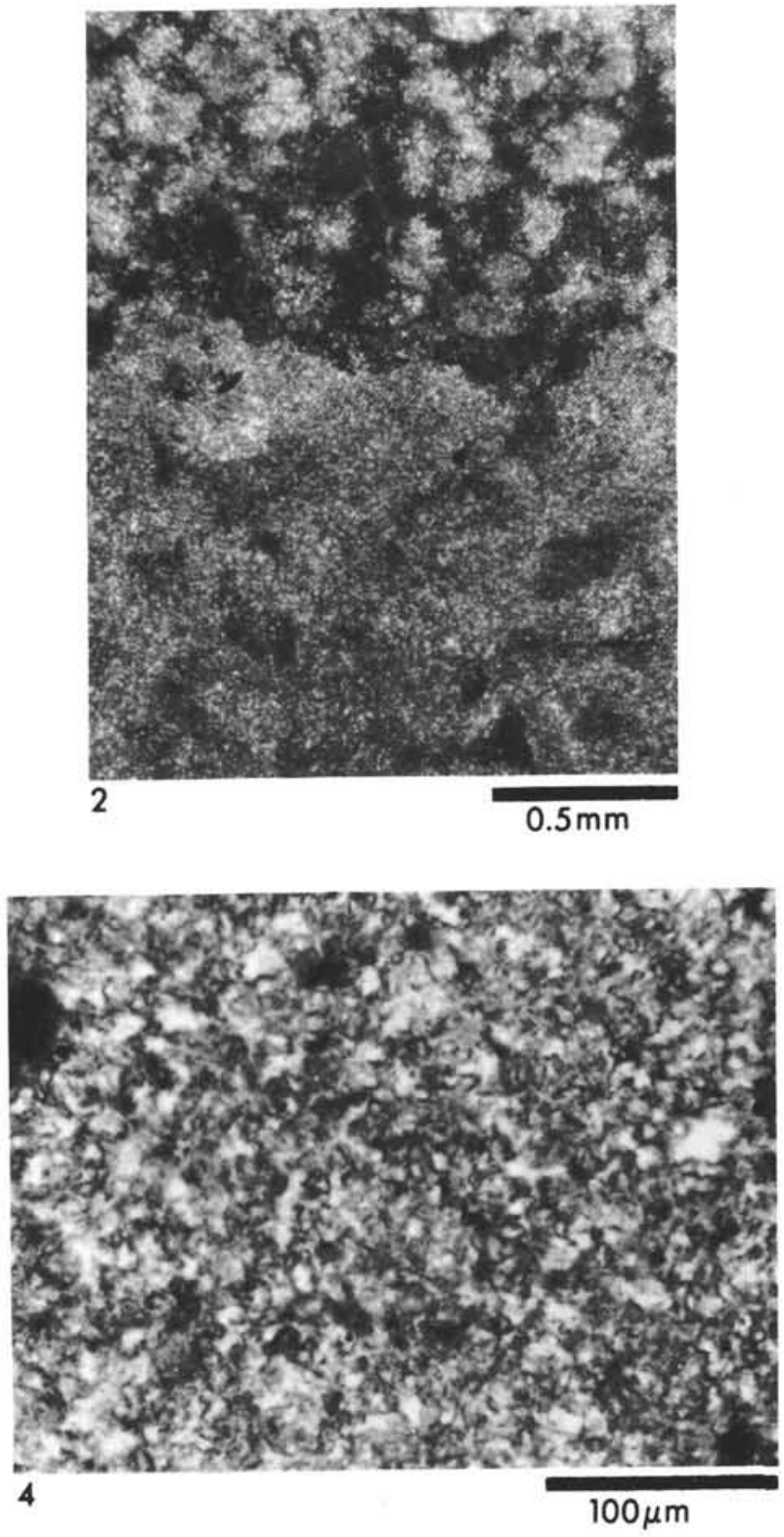

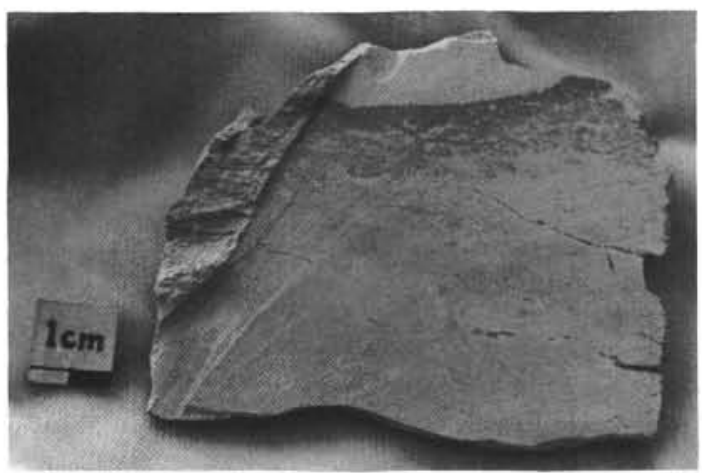

5

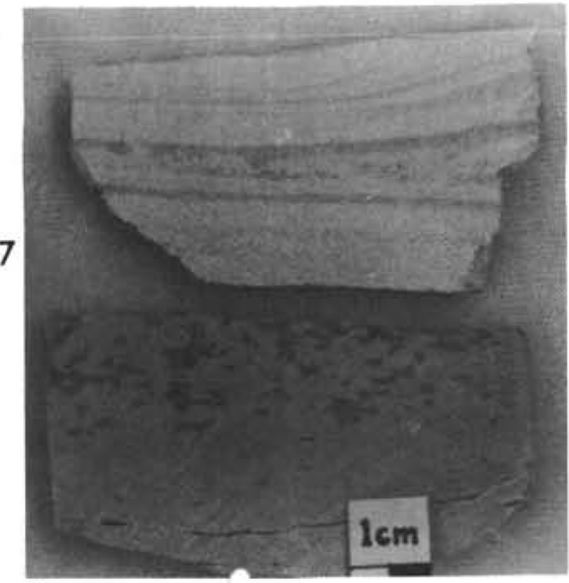

6

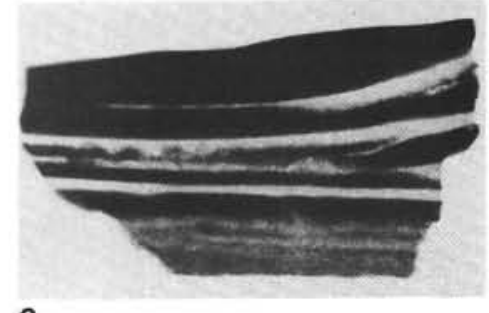

8 


\section{PLATE 13}

Site 313

Figure $138-1$ (see Plate 12, Figure 6). Photomicrograph. Contact between calcareous porcellanite (upper) and opal-CT rich porcellanite. Foraminifera at boundary has test partly replaced by chalcedony (lower) and part still calcite (upper). Opal-CT spheres occur in chamber with chalcedony. Polarized light.

Figure 2

38-1. Crossed nicols.

Figure 3 38-1 (see Plate 12, Figure 6). Photomicrograph. Foraminiferal test replaced by chalcedony; opalCT spheres and chalcedony fill chambers. Matrix is opal-CT and chalcedony. Polarized light.

Figure 4

38-1. Crossed nicols.

Figure 5 38-1. SEM photo of Plate 12, Figure 6. Platy opal$\mathrm{CT}$ hemisphere partly filling a foraminiferal chamber. Calcite has recrystallized in the walls of the test and opal-CT growth postdates this recrystallization (arrow).

Figure 6 38-1. SEM enlargement of Figure 5, showing platy habit of opal-CT. 
PLATE 13

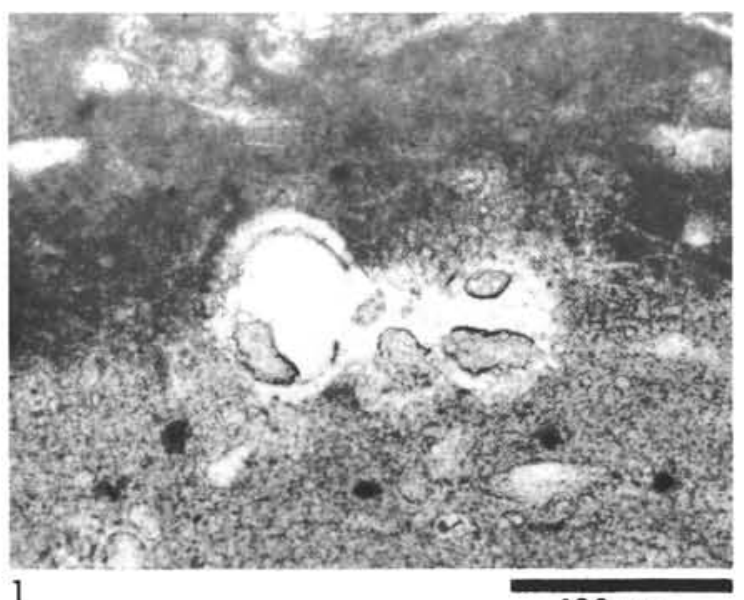

$100 \mu \mathrm{m}$
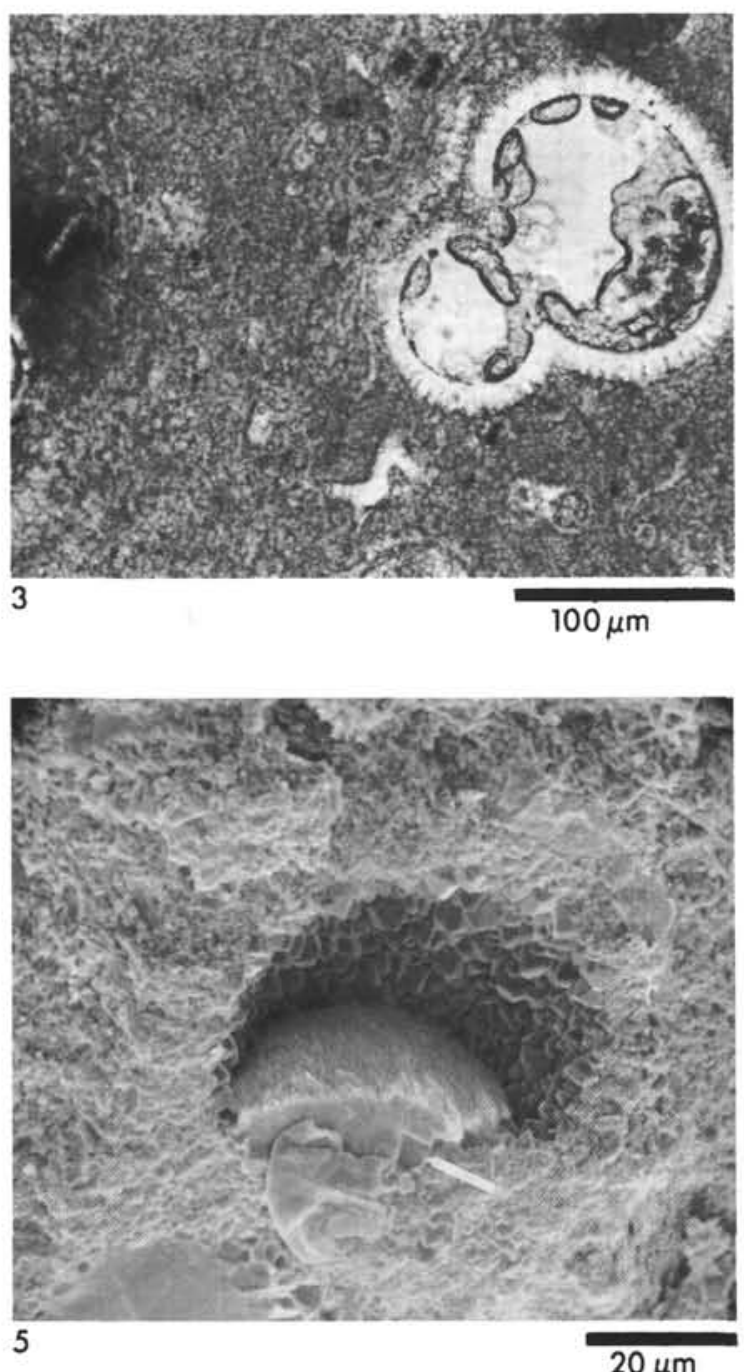
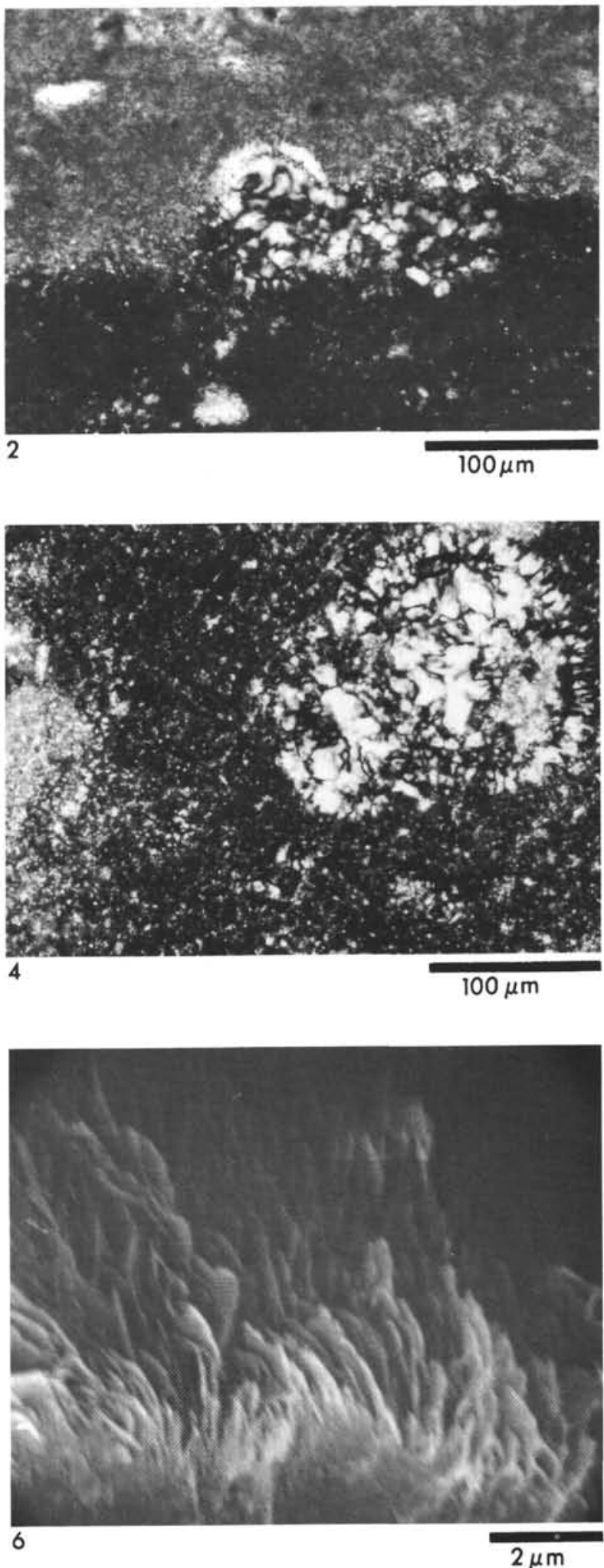


\section{PLATE 14}

\section{Site 313, SEM Photos}

Figure $155-0$ (see Plate 11, Figure 1). Incipient formation of opal-CT spheres inside foraminiferal chambers in calcareous porcellanite. Rock matrix is dominantly coccoliths and calcite grains partly cemented by platy opal-CT.

Figure 2 5-0. Plates of opal-CT growing on calcite wall of foraminiferal test.

Figure 3 5-0. Matrix of coccoliths and calcite crystals cemented by opal-CT plates. Note the porosity of this calcareous porcellanite.

Figure 4 5-0. Contact between calcareous porcellanite (upper) and chert (lower). The chert is dense and massive.

Figure 5 5-0. Chert (opal-CT and chalcedony, see Plate 11, Figures 5 and 6) with minor inclusions of carbonate and voids.

Figure 6

5-0. Opal-CT lining a void. 
PLATE 14

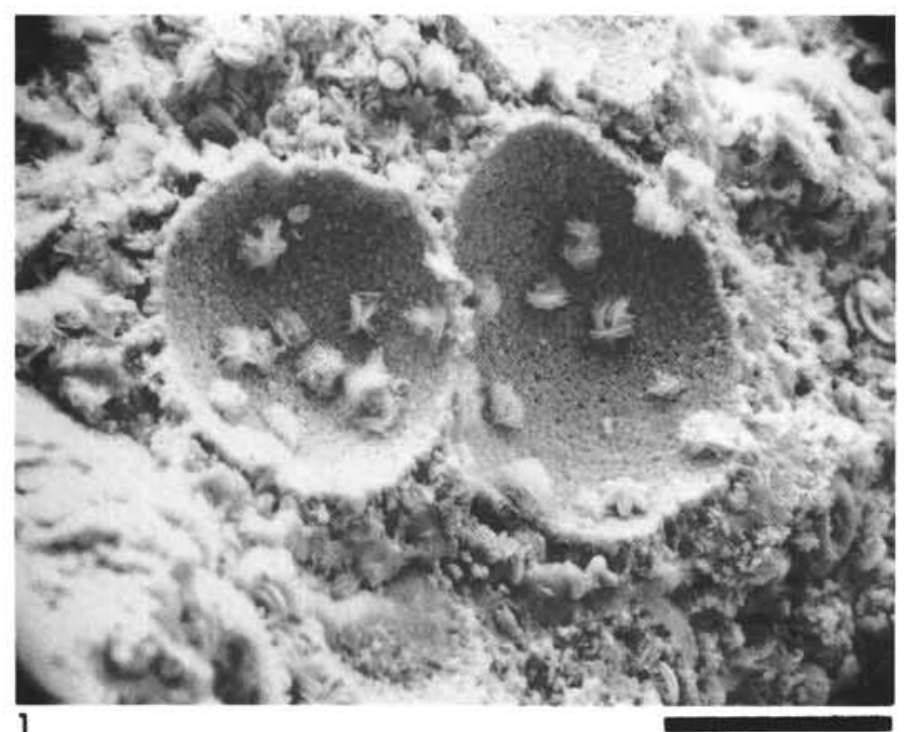

$50 \mu \mathrm{m}$
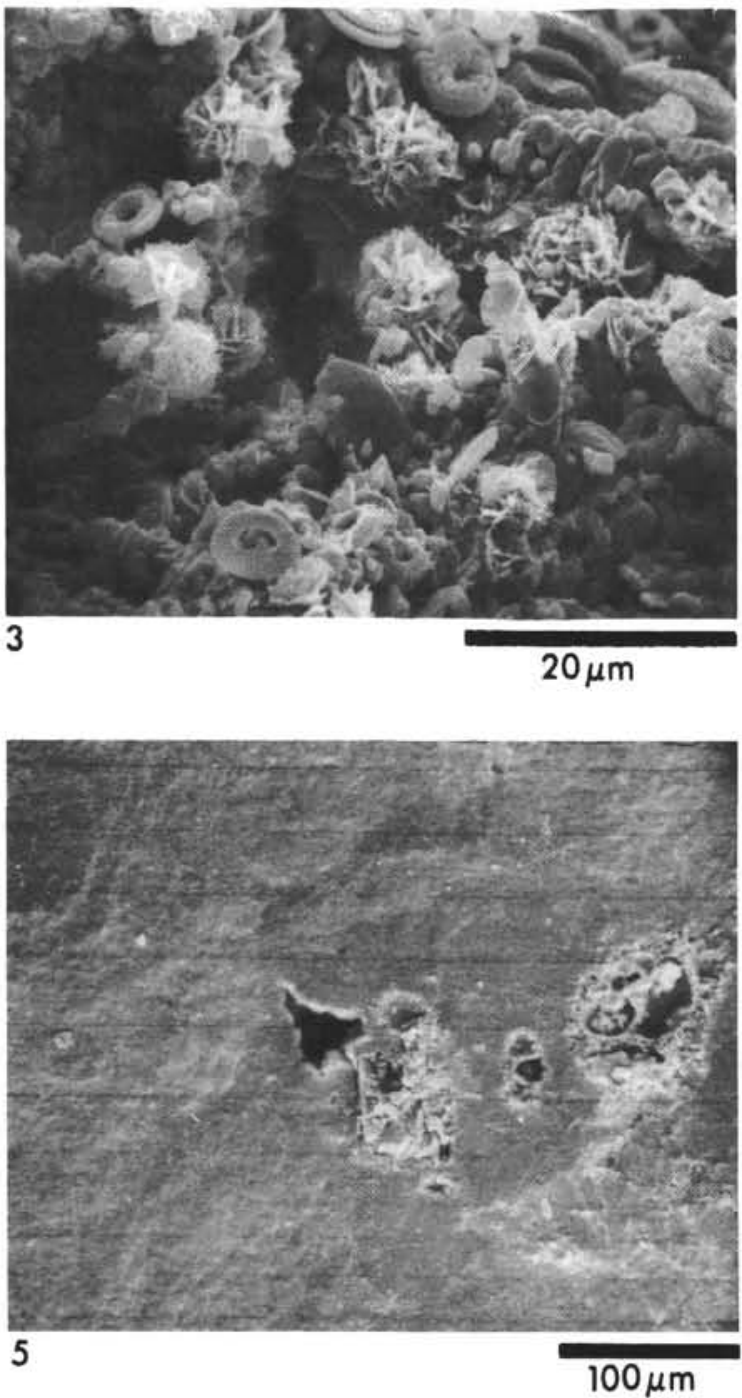
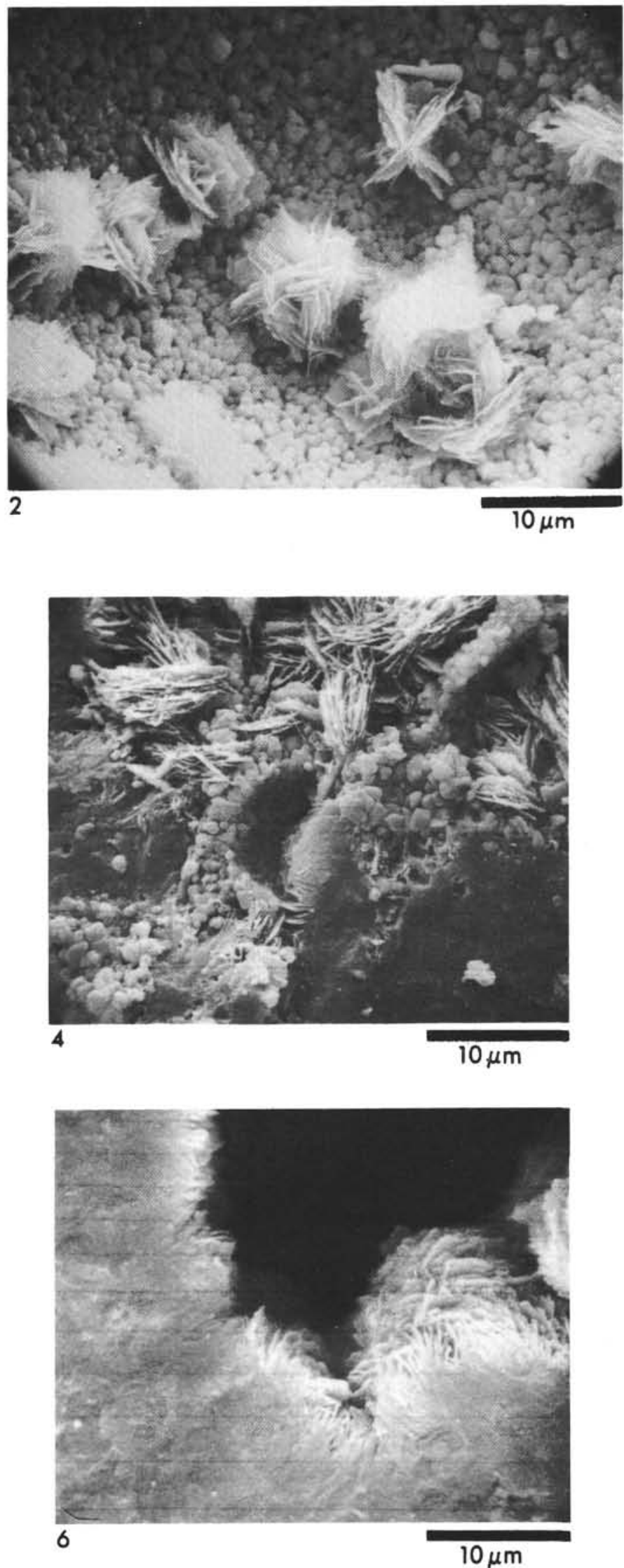
PLATE 15

Site 313, SEM Photos

Figure 15 5-0 (see Plate 11, Figure 1). Calcareous porcellanite containing abundant foraminifer.

Figure 2 5-0. Enlargement of Figure 1 showing biserial foraminifer (calcite). Opal-CT is cementing the sediment by growing out from the walls of the foraminifera. Opal-CT is also precipitating in the foraminiferal chambers.

Figure 3 5-0. Planispiral or trochospiral foraminifer. Walls are calcite.

Figure 4 5-0. Enlargement of Figure 3 showing coccoliths and foraminiferal wall (both calcite) cemented by opal-CT.

Figure $5 \quad 5-0$. Near the chert the calcareous porcellanite becomes less porous as the initially platy opal-CT fills the pores and replaces the carbonate.

Figure 6 5-0. Enlargement of Figure 5. Foraminiferal wall has not yet been replaced by silica. Opal-CT spheres fill the chamber. 
PLATE 15
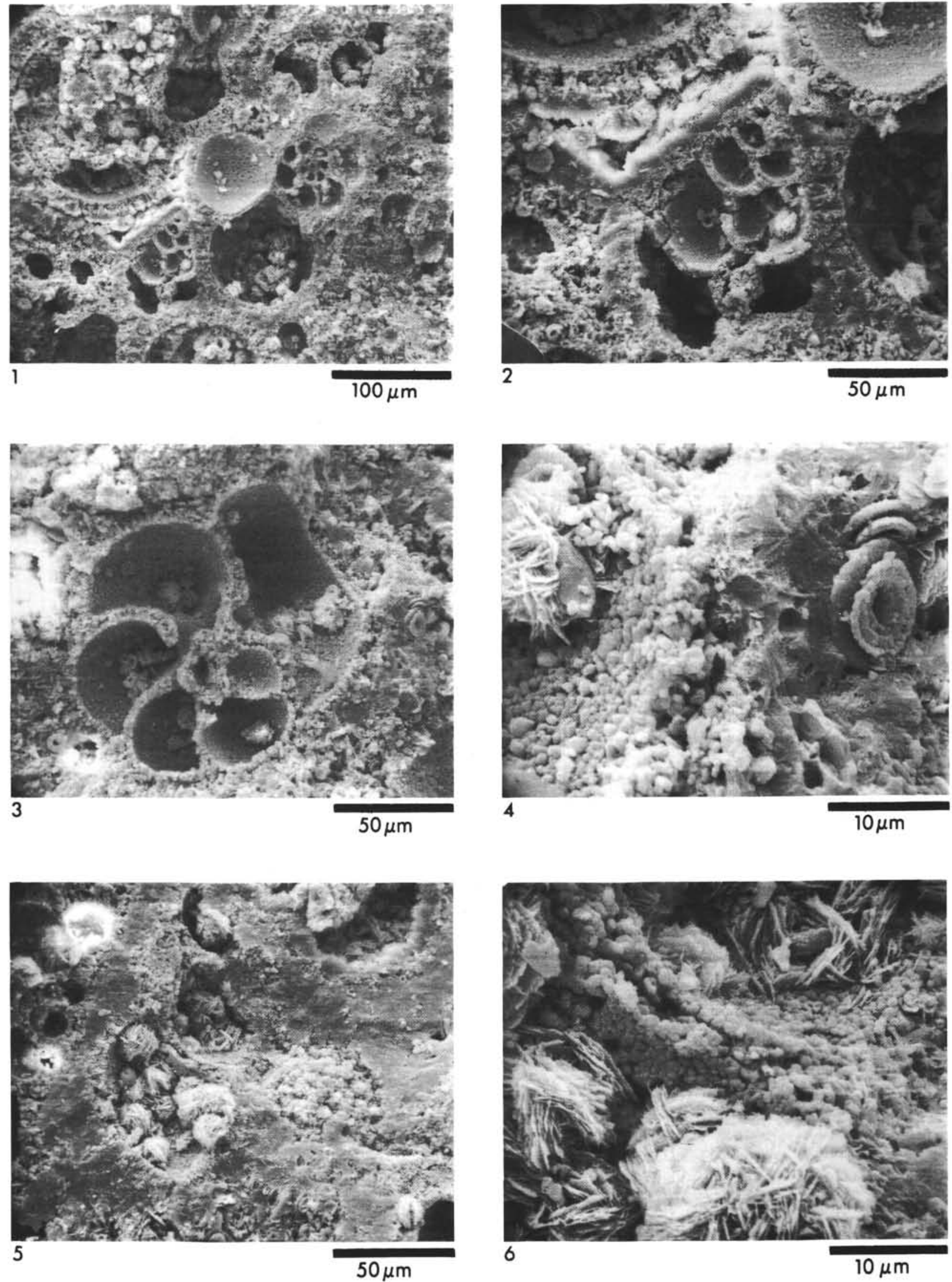


\section{PLATE 16}

Site 313, SEM Photos

Figure 1

Figure 2

Figure 3

Figure 4

Figure 5

Figure 6
5-0. (see Plate 11, Figure 1). Contact between calcareous porcellanite (left) and chert (right). Foraminifera are abundant.

5-0. Element map of Figure 1 showing distribution of silicon. The chert and the matrix between the foraminifera are siliceous.

5-0. Element map of Figure 1 showing distribution of calcium, mainly foraminiferal tests.

5-0. Enlargement of Figure 1 showing opal-CT lining a void at the edge of the chert and a foraminiferal chamber containing a cluster of opal-CT plates.

5-0. Element map of Figure 4 showing distribution of silicon.

5-0. Element map of Figure 4 showing distribution of calcium. Foraminiferal tests are the last remaining calcite. 
PLATE 16
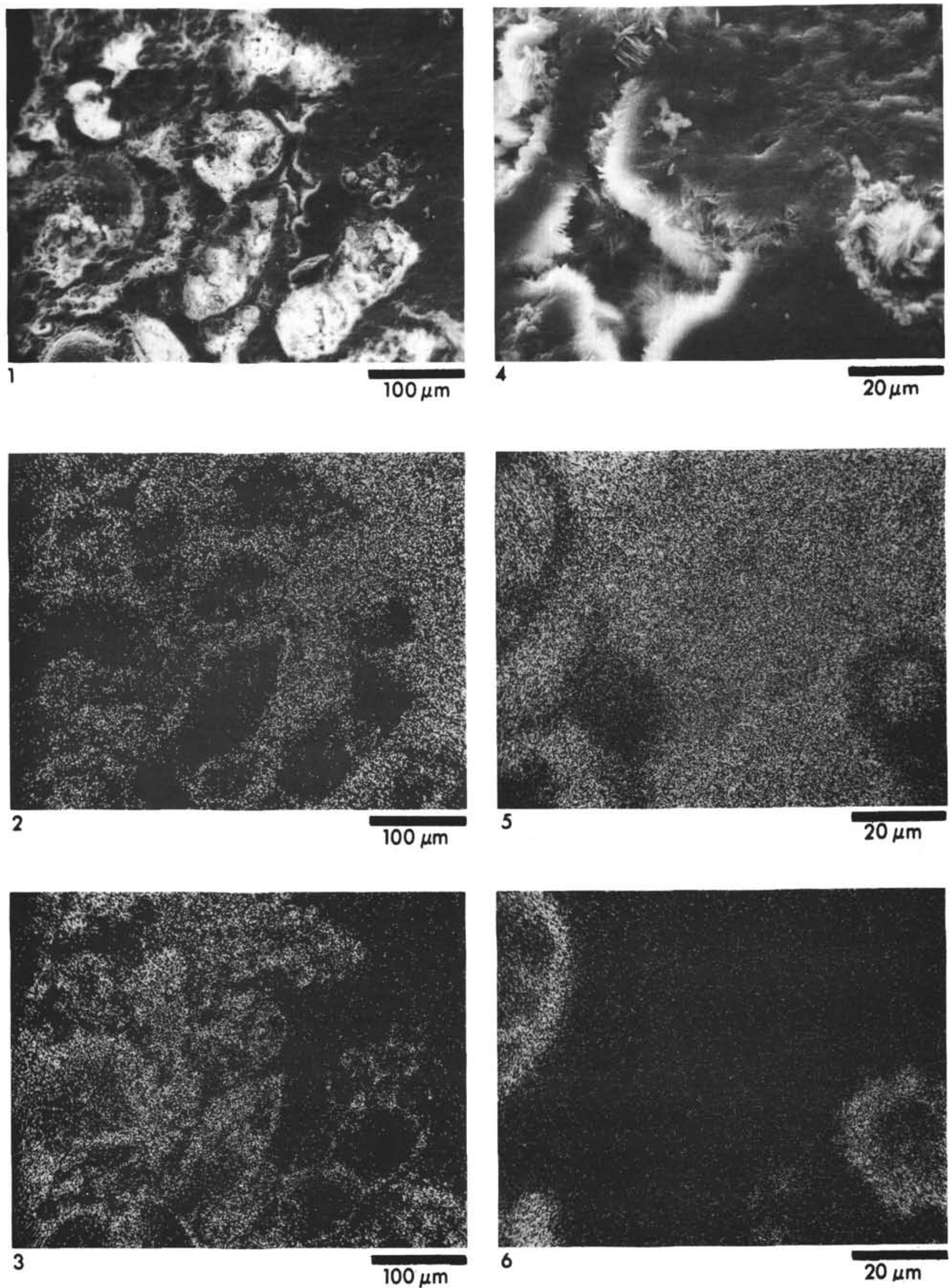


\section{PLATE 17}

\section{Site 313, SEM Photos}

Figure 1

13-1 (214 m: early Eocene). Partly lithified calcareous radiolarian ooze. Foraminifera, coccoliths, calcite crystals, and radiolarians are common. Badly etched radiolarian spine shows layering of the opal-A (arrow).

Figure 2 13-1. Etched radiolarian fragments, coccoliths and calcite crystals. A thread-like substance, perhaps some form of opal, joins particles (arrows) and forms an incipient cement.

Figure 3 13-1. Remaining radiolarian network after treatment of Figure 1 with $\mathrm{HCl}$ and $\mathrm{H}_{2} \mathrm{O}_{2}$.

Figure 4 13-1. Enlargement of Figure 3 showing bridges, which consist of silica, joining radiolarian fragments (arrows).

Figure 5 13-1. Discoaster barbadiensis with calcite overgrowths. Calcite crystals, etched coccoliths and etched radiolarian fragments are also present. 
PLATE 18
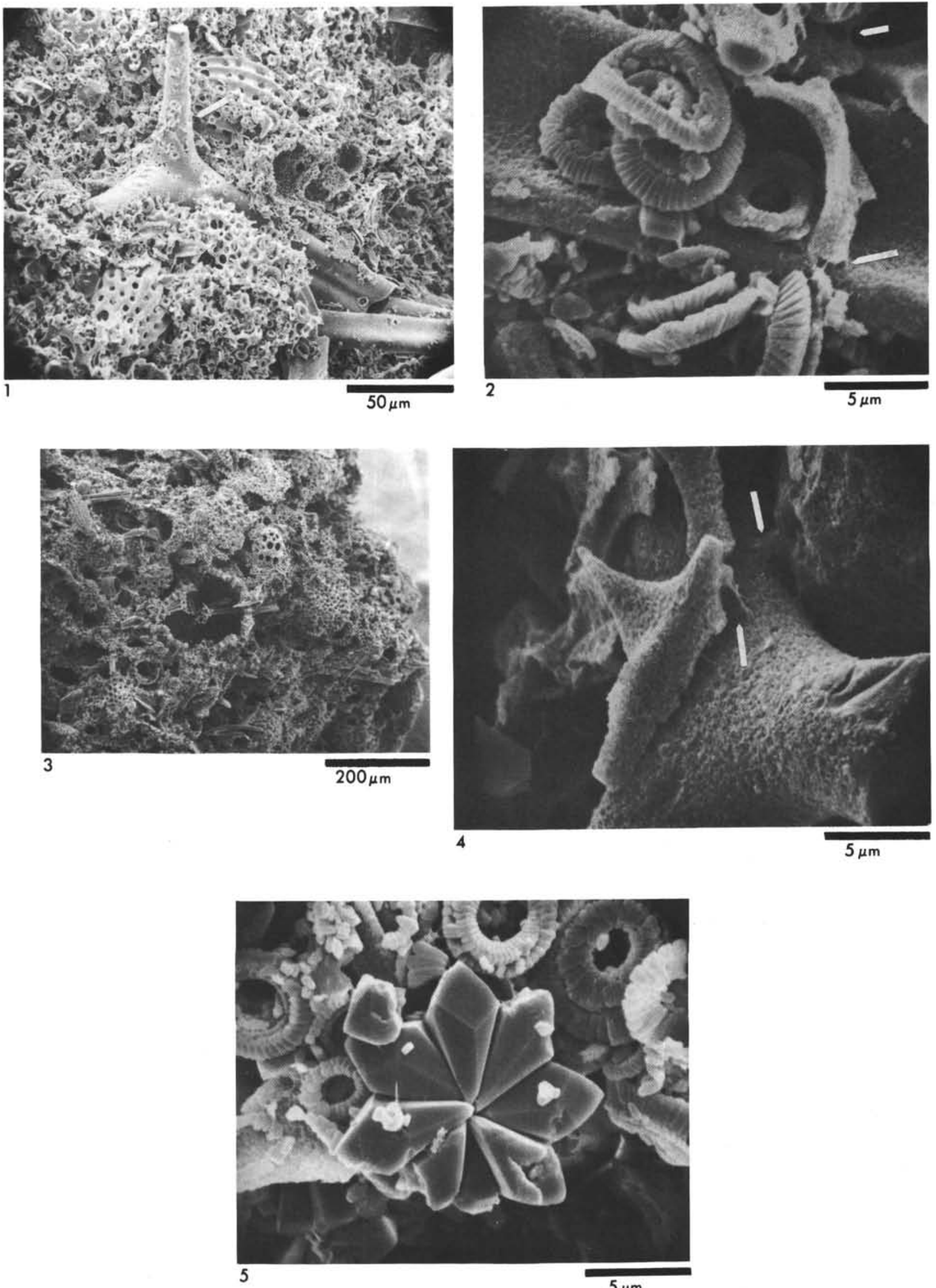
Figure 12 2, CC (220 m: Cenomanian/Albian). Typical bedded brown chert with inclusions of porcellanite. Bedding continues from chert into porcellanite.

Figure 2 3, CC (239 m: Albian). Brown porcellanite, laminated.

Figure 34 4, CC (248 m: Aptian/Barremian). Brown chert with porcellanite inclusions.

Figure $4 \quad 5-2(250 \mathrm{~m}$ : Barremian/Hauterivian). Greenish bedded chert with fracture and disturbed bedding now silicified with clear chalcedony.

Figure 5 5-2. Gray porcellanite with two areas now filled with chalcedony and microquartz.

Figure 6 6-1. (257 m: Barremian/Hauterivian). Bedded porcellanite mottled pale and dark brown.

Figure 7 6-1. Brown chert fractured and cemented with clear chalcedony. Chalcedony has a botryoidal surface and once lined a void.

Figure 8 6-1. Photomicrograph of Figure 7 showing barite crystal and opaque iron and manganese needle clusters in clear chalcedony. This chalcedony cements the angular fragments in Figure 7. Polarized light.

Figure 9 6-1. Crossed nicols. The needle clusters are concentrated along a surface where chalcedony grain size changes perhaps indicating a break in precipitation. 
PLATE 17
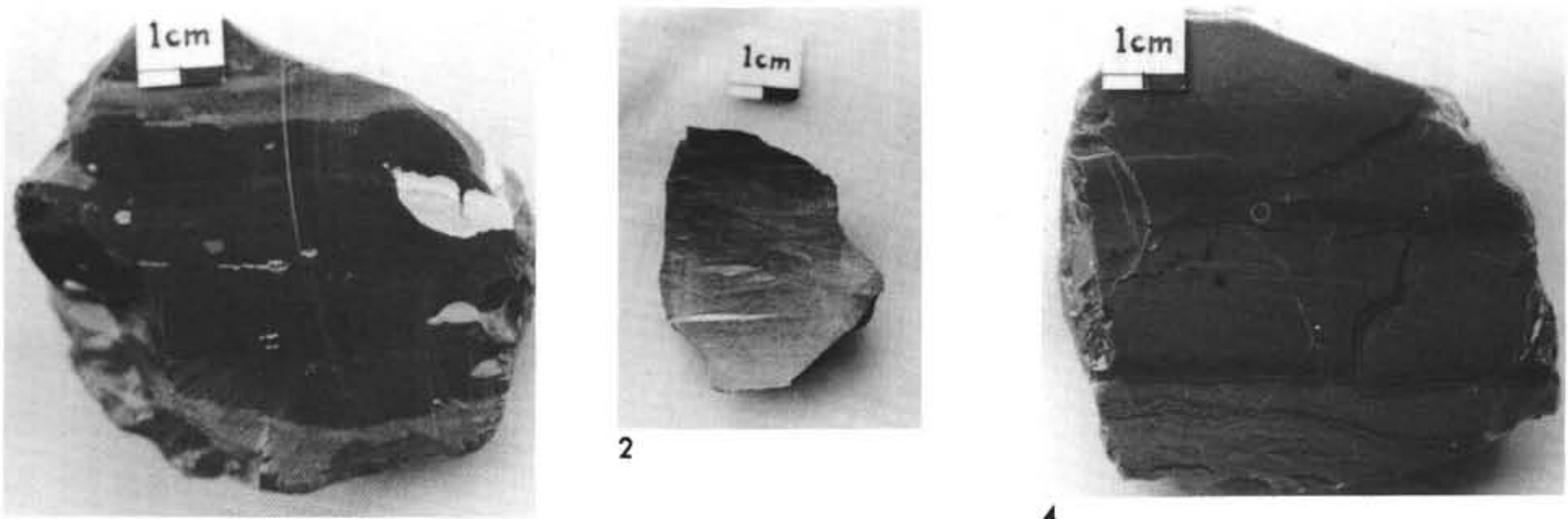

1
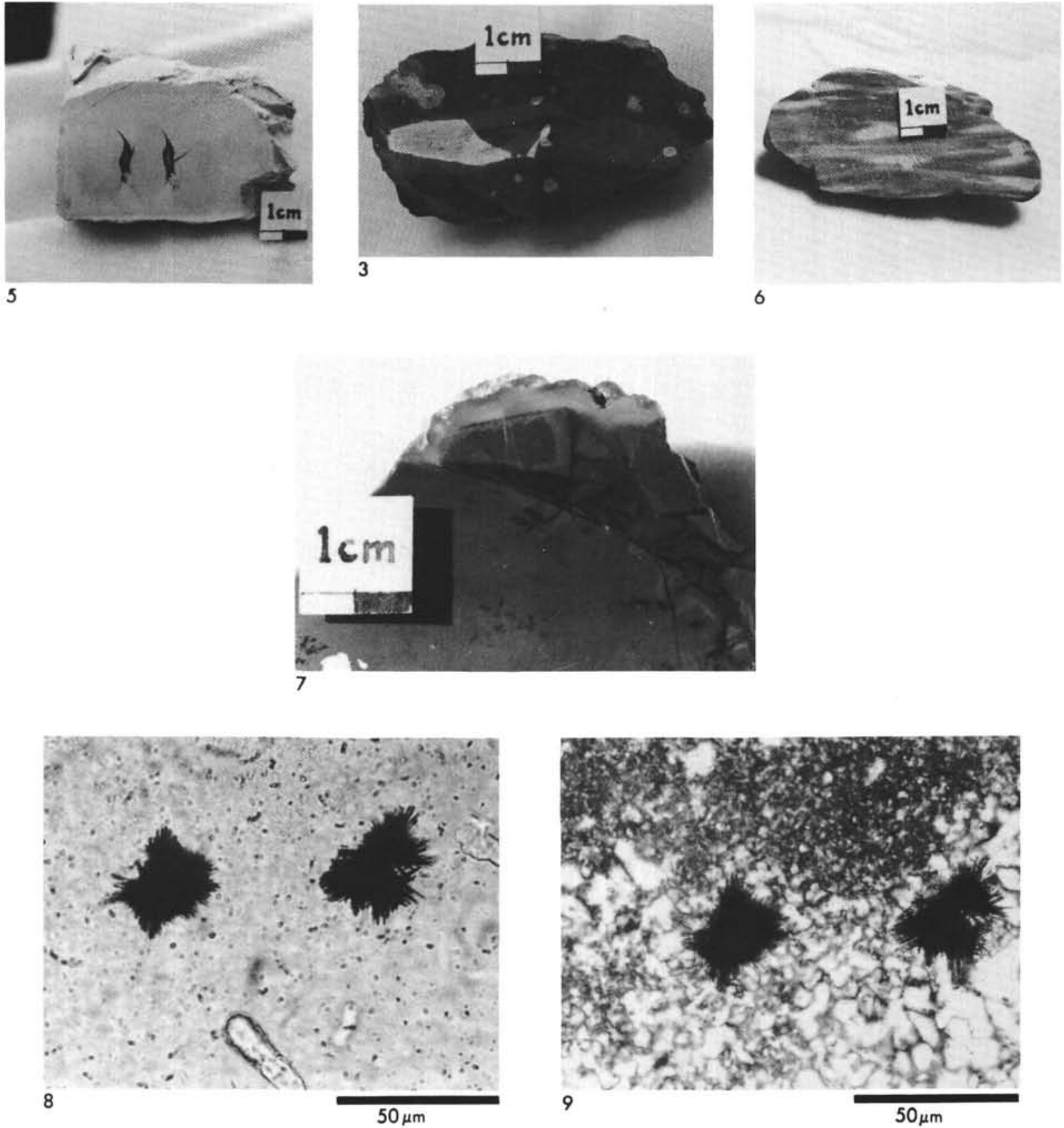


\section{PLATE 19}

Site $303 \mathrm{~A}$

Figure 12 2, CC (see Plate 18, Figure 1). Photomicrograph of typical brown chert. Abundant radiolarian ghosts. Some radiolarians, coated or replaced by opaque material, have test details preserved. Polarized light.

Figure 2 2, CC. SEM photo of transition zone between quartzose chert (left) and porcellanite (right). Porcellanite is porous, massive opal-CT.

Figure 3 2, CC. Photomicrograph of contact between radiolarian-rich chert (lower) and porcellanite (upper). Porcellanite contains fewer radiolarians. Polarized light.

Figure 4

2, CC. Crossed nicols.

Figure 53 3, CC (see Plate 18, Figure 2). Photomicrograph of vertical thin section of porcellanite showing bedding and radiolarians. Crossed nicols.

Figure 63 3, CC. Photomicrograph of horizontal thin section of Figure 5 showing many radiolarian spines (or sponge spicules) in random orientation. Crossed nicols. 
PLATE 19
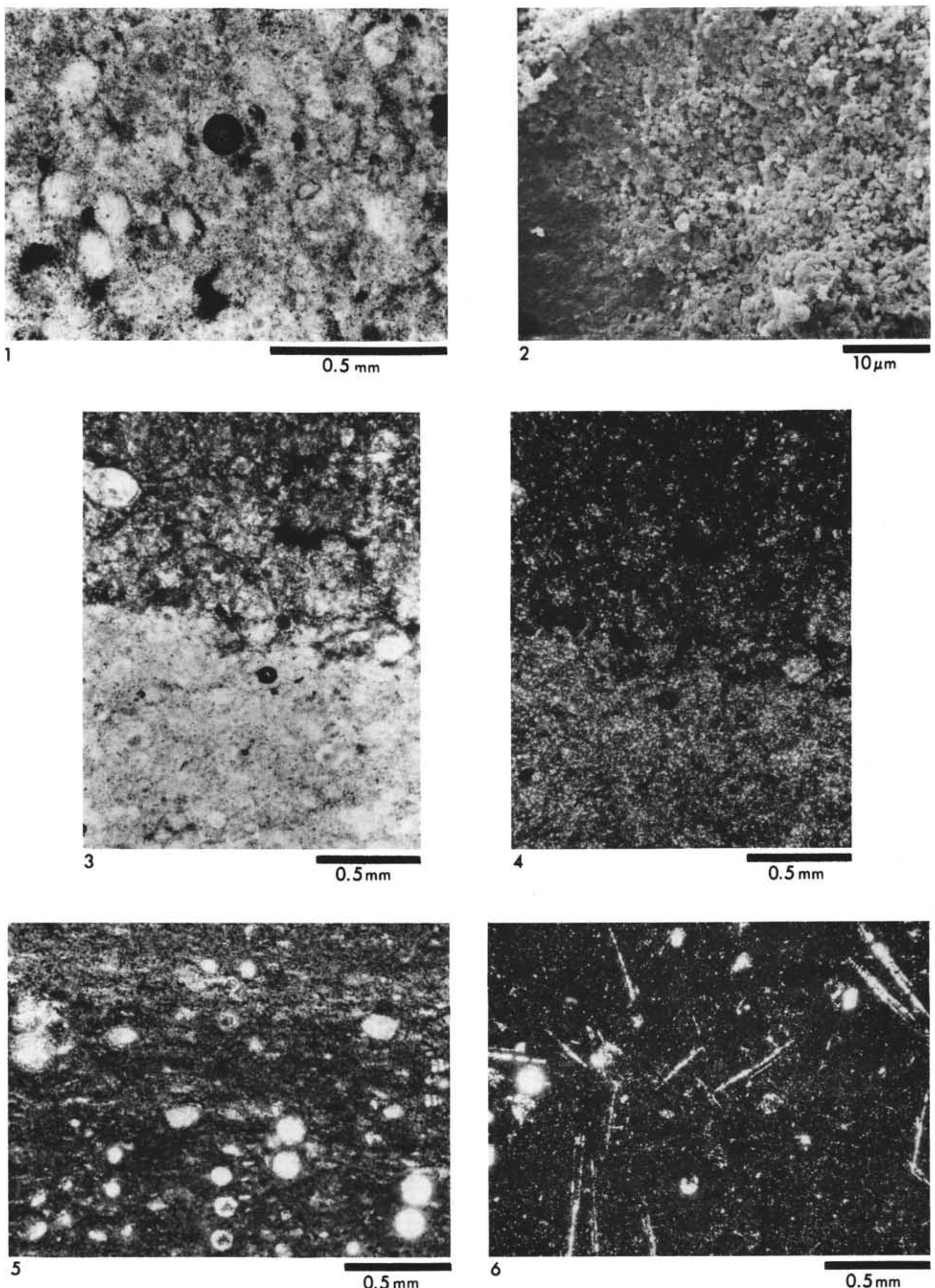
PLATE 20

Figure 1 303A-3, CC (see Plate 18, Figure 2). Photomicrograph of porcellanite containing fine details of radiolarian test in massive opal-CT with minor chalcedony. Test is opal-CT and filled with chalcedony. Polarized light.

Figure 2 303A-3, CC. Crossed nicols. Opal-CT appears isotropic.

Figure 3 303A-3, CC. Photomicrograph of porcellanite containing Nassellaria radiolarian test, now opalCT. Narrow end of test is filled with opal-CT. Polarized light.

Figure 4 303A-3, CC. Crossed nicols. Bulk of test is filled with radiating chalcedony.

Figure 5 303A-6-1 (see Plate 18, Figure 6). Photomicrograph of porcellanite containing radiolarian test replaced by opal-CT. Chalcedony fills the test forming a perfect internal mold. Note difference in refractive index of opal-CT and chalcedony. Polarized light.

Figure 6 307-7-1 (see Plate 27, Figure 4). Photomicrograph of radiolarians (opal-CT) filled by chalcedony in massive opal-CT porcellanite. Polarized light. 
PLATE 20
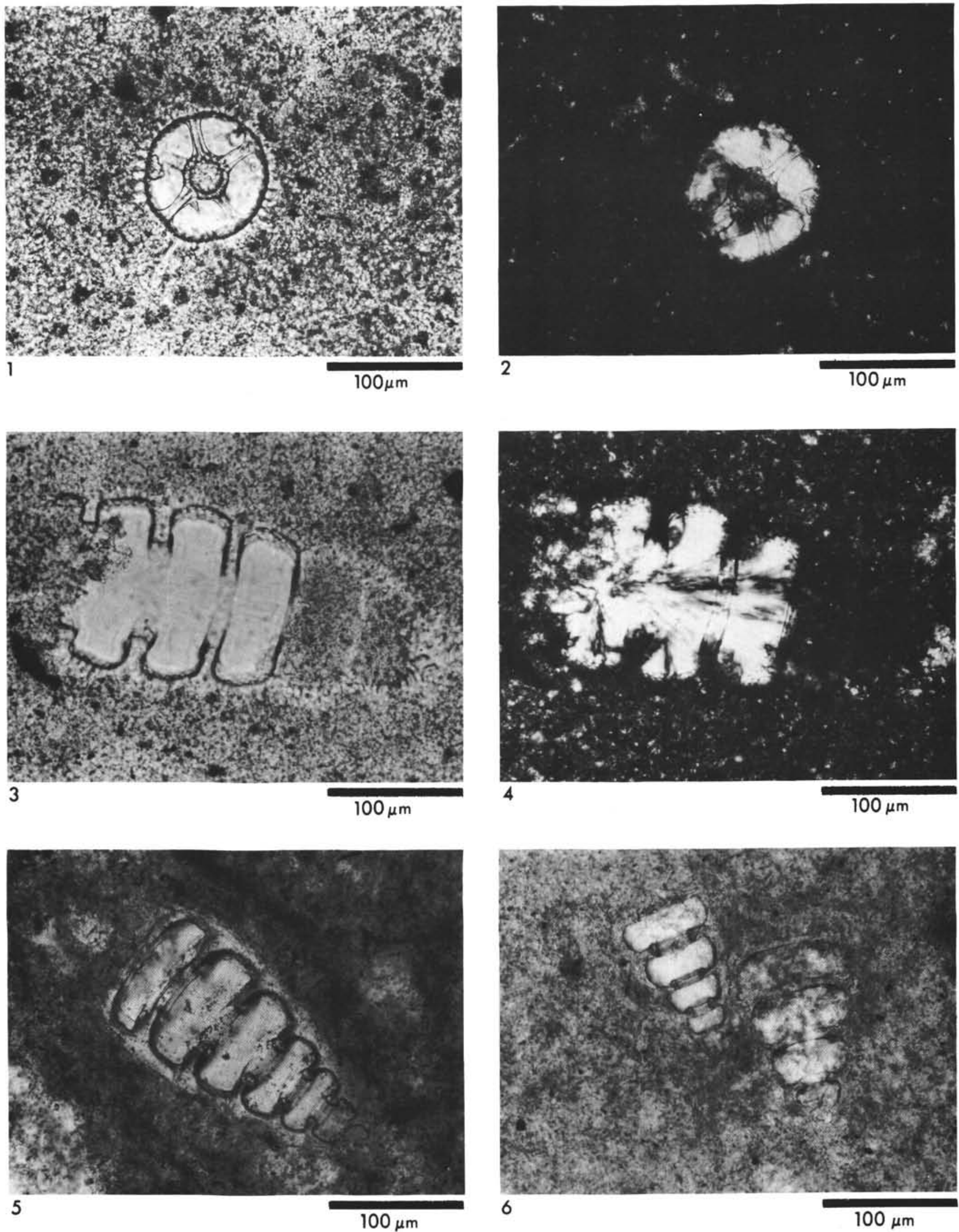


\section{PLATE 21}

Site 303A

Figure 14 , CC (see Plate 18, Figure 3). Photomicrograph of chert containing radiolarian test coated or replaced by opaque material. Details of test are well preserved. Polarized light.

Figure 24 , CC. Crossed nicols. Chalcedony fills test and forms surrounding chert.

Figure 3 5-2 (see Plate 18, Figure 5). Photomicrograph of fracture in porcellanite filled by sheafs of chalcedony and macroquartz. Crossed nicols.

Figure 4 5-2 (see Plate 18, Figure 5). Photomicrograph of fractures in radiolarian-bearing porcellanite (massive opal-CT). Polarized light.

Figure 5 6-1 (see Plate 18, Figure 6). Photomicrograph of typical radiolarian-bearing porcellanite. Some flattening of radiolarians parallel to bedding occurs. Opaque material is concentrated in patches. Polarized light.

Figure 6 6-1. Crossed nicols. 
PLATE 21
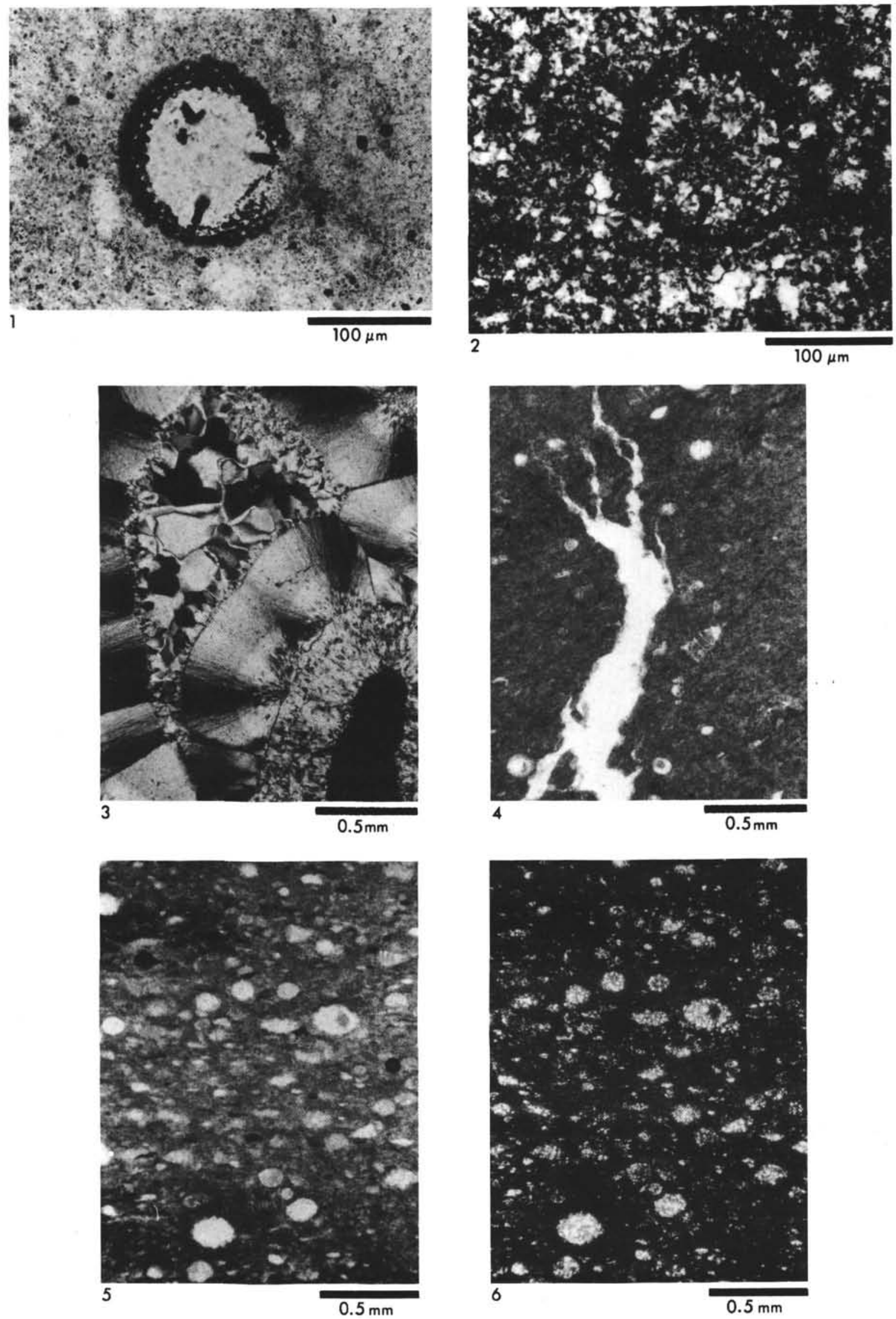


\section{PLATE 22}

Site $303 \mathrm{~A}$

Figure 15 5, CC (257 m: Barremian/Hauterivian). Photomicrograph of green chert with no visible organic remains. Texture is uniform, small (10 to $15 \mu \mathrm{m})$ grains of chalcedony. Chert contains a cluster of euhedral barite crystals (arrow) and veins containing macroquartz. Polarized light.

Figure 2 5, CC. Crossed nicols.

Figure 3 6-1. (see Plate 18, Figure 7). Photomicrograph of chalcedony cementing fragments of a radiolarian chert. Three periods of silicification occur in this fracture. Boundaries are marked by textural changes and, on the stratigraphically lower side, by a zone of barite and iron and manganese minerals. Polarized light.

Figure 4 6-1. Crossed nicols.

Figure 5 7, CC (276 m: Hauterivian/Valanginian). Photomicrograph of brown chert containing brown and opaque iron and manganese minerals with clays. Radiolarians are partly flattened. Polarized light.

Figure 6 8, CC (285 m: Hauterivian/Valanginian). Photomicrograph of chert containing many late fractures filled with microquartz which cut chalcedony-filled radiolarians. Polarized light. 
PLATE 22
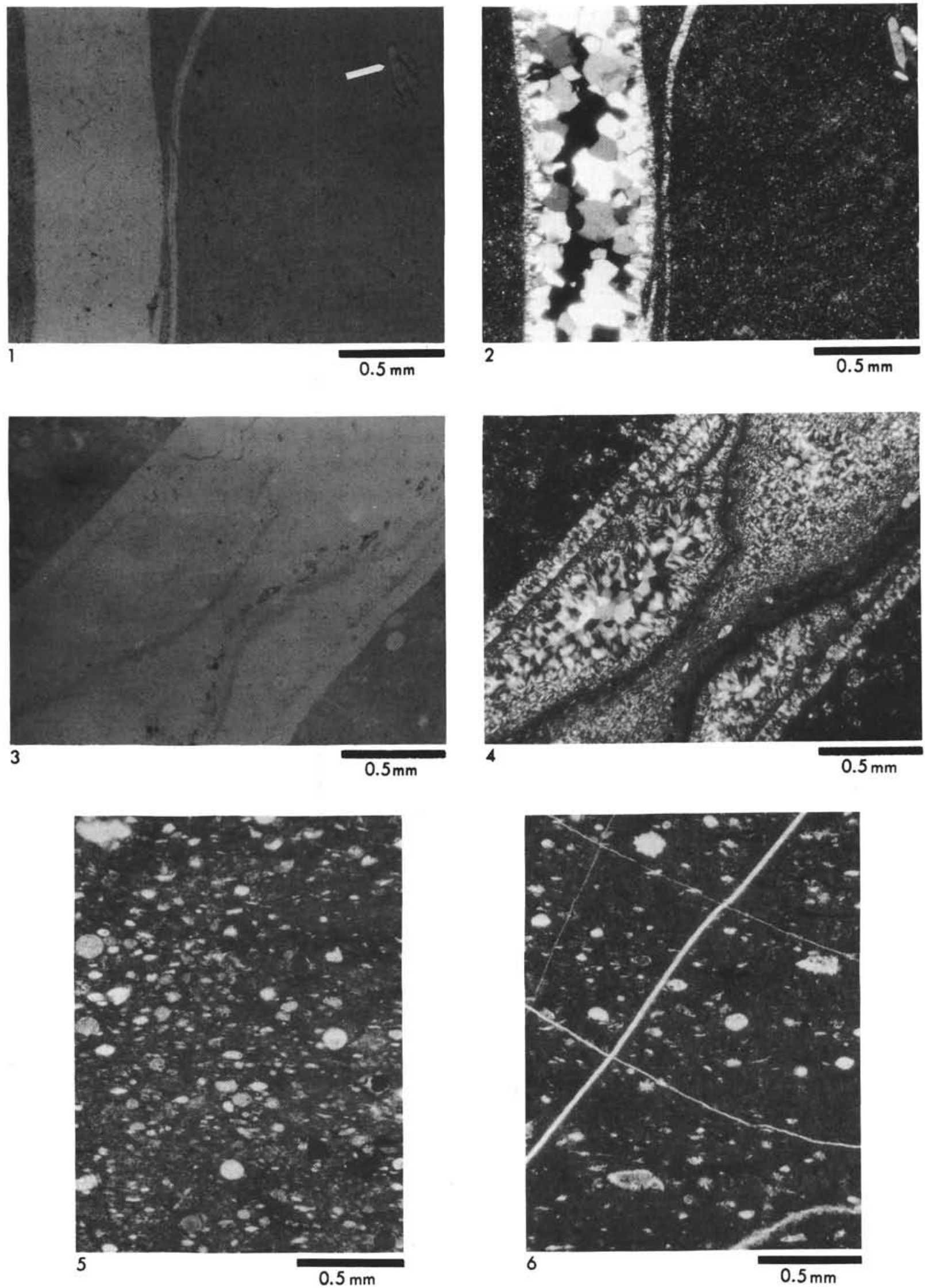


\section{PLATE 23}

Site 304

Figure 1 5-1 (254 m: Aptian/Barremian). Breccia of angular opal-CT porcellanite (pale color) and chert fragments silicified by brown chalcedony. Bedding is vertical in some fragments.

Figure 24 4, CC (253 m: Albian). Chert fragments with diffuse margins cemented by clear chalcedony.

Figure 3 8-1 (281 m: Barremian/Hauterivian). Angular chert fragments cemented by clear chalcedony.

Figure $4 \quad 7-1$ (272 m: Aptian/Barremian). Typical brown porcellanite. Thin laminae are faintly visible.

Figure 5 5-1. Photomicrograph of Figure 1. Fragments of radiolarian-bearing porcellanite and chert. Matrix is fine-grained chalcedony with clays and other impurities. Polarized light.

Figure $6 \quad 5-1$. Crossed nicols.

Figure 74 4, CC. Photomicrograph of Figure 2. Radiolarian chert fragments with diffuse boundaries cemented by chalcedony. Polarized light.

Figure 8 4, CC. Crossed nicols. 
PLATE 23
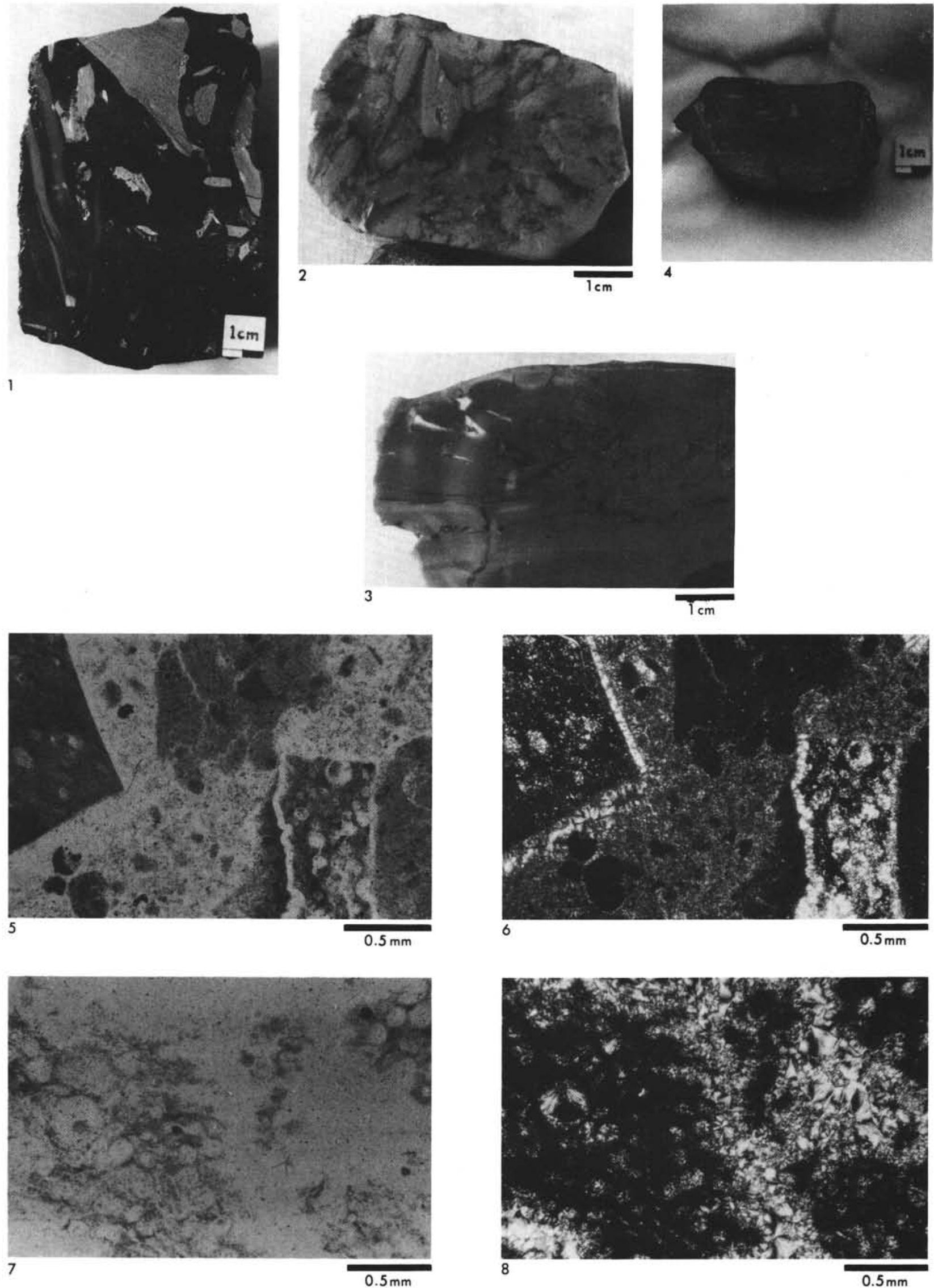


\section{PLATE 24}

\section{Site 304}

Figure 1

7-1 (see Plate 23, Figure 4). Photomicrograph of typical brown, bedded, opal-CT rich porcellanite. Radiolarians are filled with opal-CT or chalcedony. Polarized light.

Figure 2 8-1 (see Plate 23, Figure 3). Photomicrograph of chert with chalcedony filled veins. The margins of the veins have a conchoidal fracture. The veins only occur in the chert layer containing radiolarians suggesting that the radiolarian layer was silicified prior to the silicification of the adjacent layer. Crossed nicols.

Figure $3 \quad 8-1$ (281 m: Barremian/Hauterivian). Greenish chert nodule in gray porcellanite. Vein of chalcedony has restricted the growth of the chert.

Figure 4 8-1. Photomicrograph of Figure 3. Early formed chalcedony vein dividing chert $(C)$ from porcellanite $(\mathrm{P})$. Some chert has formed in the porcellanite. Crossed nicols.

Figure 5 8-1. Photomicrograph of Figure 3 showing contact between chert (C) and porcellanite (P). Note the concentration of opaque material at boundary. Polarized light.

Figure 6 8-1. Crossed nicols. 


\section{PLATE 24}
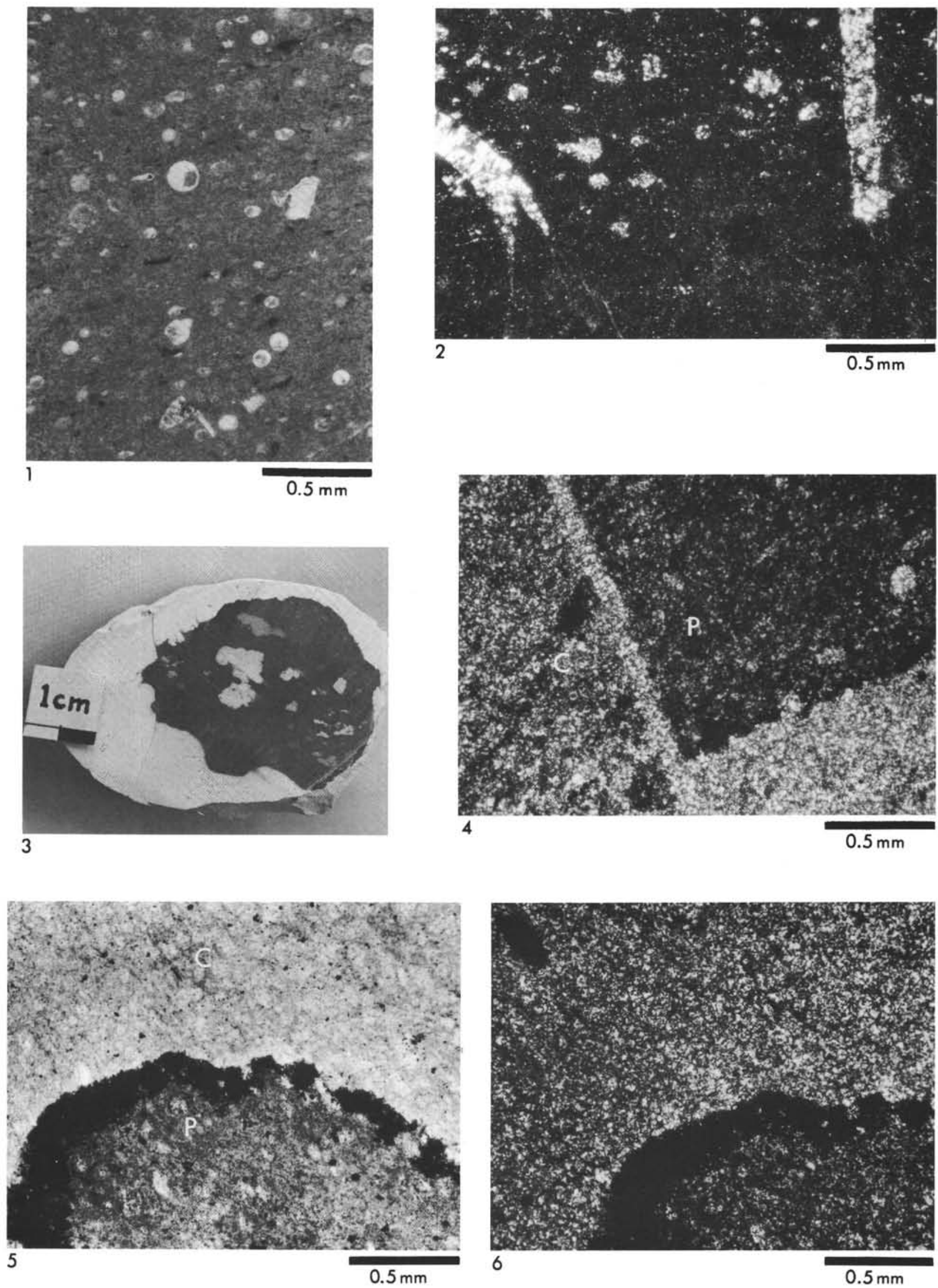


\section{PLATE 25}

Site 304

Figure $1 \quad 10-1 \quad(300 \mathrm{~m}:$ Barremian/Hauterivian $)$. Brown chert containing vugs and fractures lined with quartz crystals.

Figure 2 15-1 (335 m: Hauterivian/Valanginian). Similar to Figure 1.

Figure 3 15-1. Photomicrograph of Figure 2 showing uniform texture of chert consisting of equant microquartz grains 15 to $20 \mu \mathrm{m}$ in size. Vein filled with megaquartz. Crossed nicols.

Figure 4 10-1. SEM photo of quartz crystals lining a void in Figure 1. Grain size decreases away from the void. There is a zone of chalcedony (C) formed on the chert $(\mathrm{Ch})$ fracture. Iron and manganese mineral clusters form on the crystal faces of the quartz.

Figure 5 10-1. SEM enlargement of Figure 4 showing iron and manganese needles forming micronodules on quartz crystals. The nodules form on the slower growing prism faces of the quartz.

Figure 6 10-1. SEM enlargement of Figure 4 showing fibrous texture of chalcedony lining a fracture.

Figure 7 10-1. SEM enlargement of Figure 4 showing massive texture of chalcedonic chert. 


\section{PLATE 25}
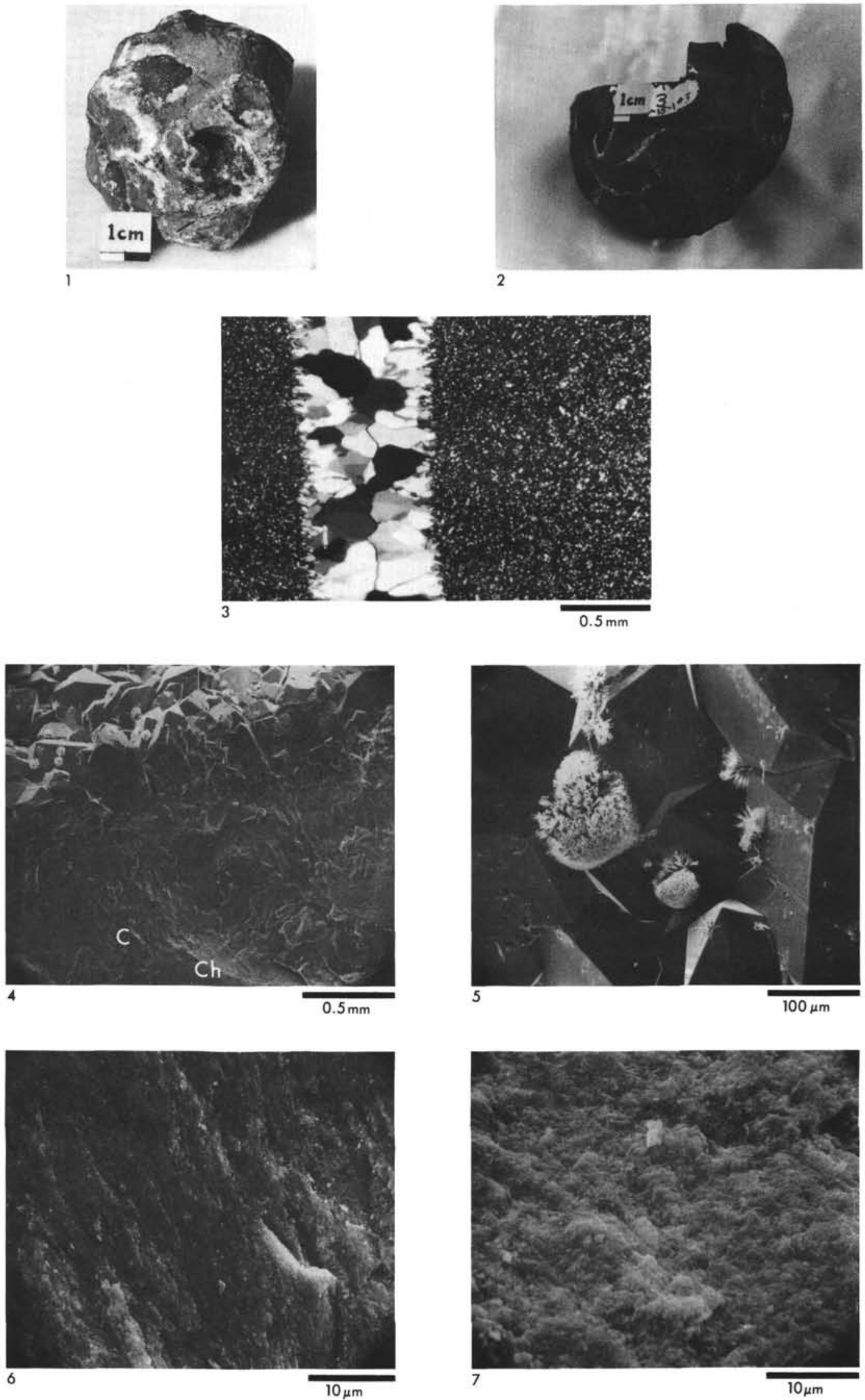


\section{PLATE 26}

Site 304

Figure 1 10-1 (see Plate 25). SEM photo of iron and manganese minerals growing in and on quartz crystals. Needles radiate from a central sphere. The needles have euhedral crystals growing in and on them.

Figure 2 10-1. SEM enlargement of Figure 1 showing central iron-rich sphere and manganese-rich crystals in and on needle.

Figure 3 10-1. Element map of Figure 2 showing distribution of iron. Iron is concentrated in the sphere and in the needle, probably as an oxide or hydroxide.

Figure 4 10-1. Element map of Figure 2 showing distribution of manganese. Manganese is concentrated in the euhedral crystals.

Figure $5 \quad$ 15-1 (see Plate 25, Figure 2). SEM photos of chert consisting of equant grains of microquartz. Quartz grains have developed a low-energy configuration and contrast with the textures illustrated in Plates 4,19 , and 25 .

Figure 6

15-1. SEM enlargement of Figure 5. 
PLATE 26
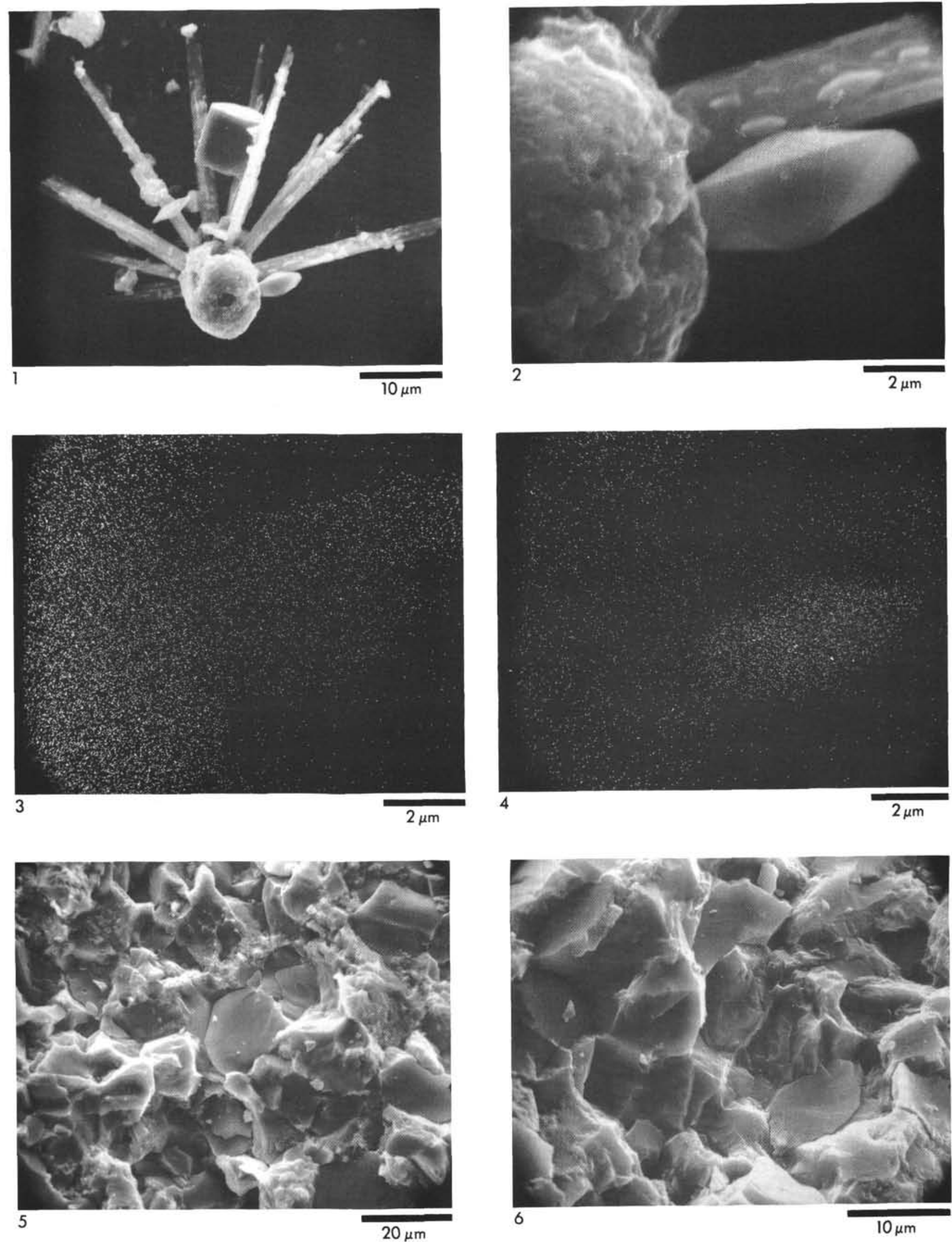


\section{PLATE 27}

Site 307

Figure 1 2-1. (38 m: Cenomanian/Albian). Bedded chert containing vug lined with quartz and botryoidal chalcedony.

Figure 2 2, CC. $(47 \mathrm{~m}$ : Cenomanian/Albian $)$. Bedded porcellanite.

Figure 34 4, CC (86 m: Albian). Brown porcellanite.

Figure $4 \quad 7-1 \quad$ (158 m: Hauterivian/Valanginian). Gray porcellanite.

Figure $5 \quad 6$, CC (131 m: Barremian/Hauterivian). Brown bedded chert with some porcellanite inclusions.

Figure 64 , CC. Photomicrograph of Figure 3 showing radiolarians filled with chalcedony (some with a little opal-CT) in massive opal-CT porcellanite. Polarized light.

Figure 7

4, CC. Crossed nicols.

Figure 8 6, CC. Photomicrograph of Figure 5. Radiolarian-rich chert. Polarized light.

Figure 9 6, CC. Crossed nicols. 
PLATE 27
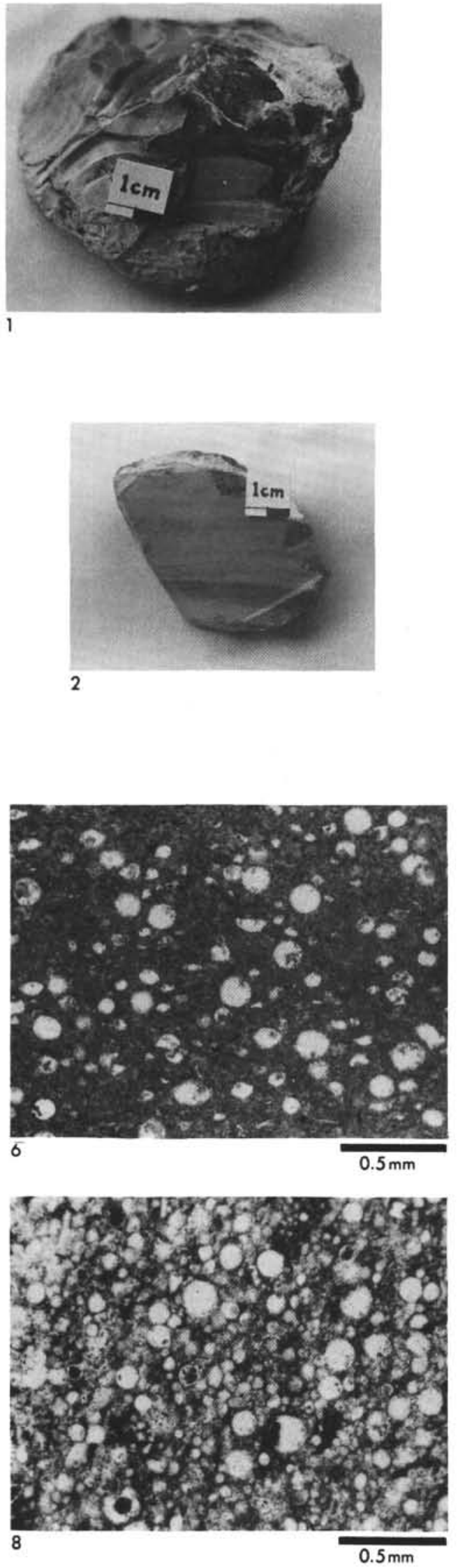

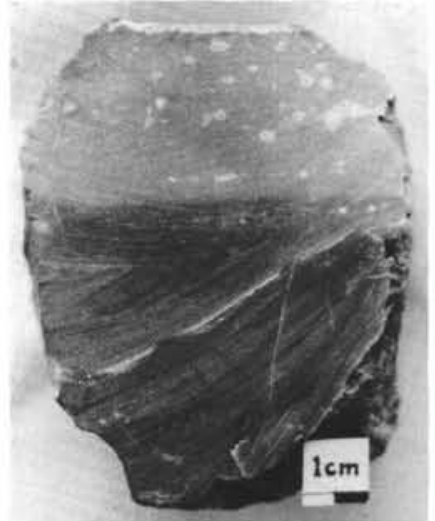

5

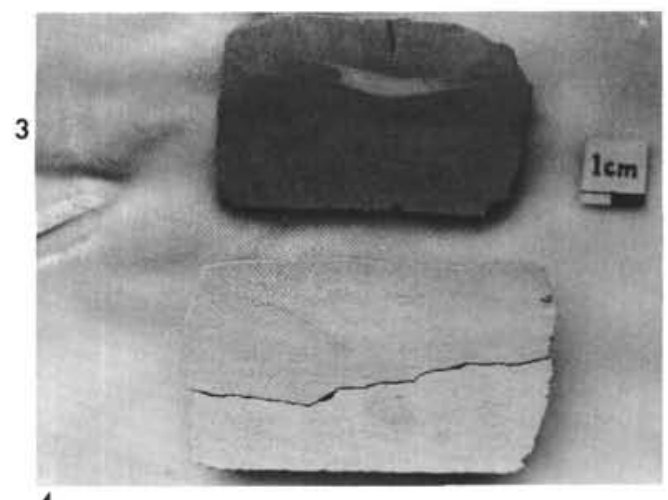

4
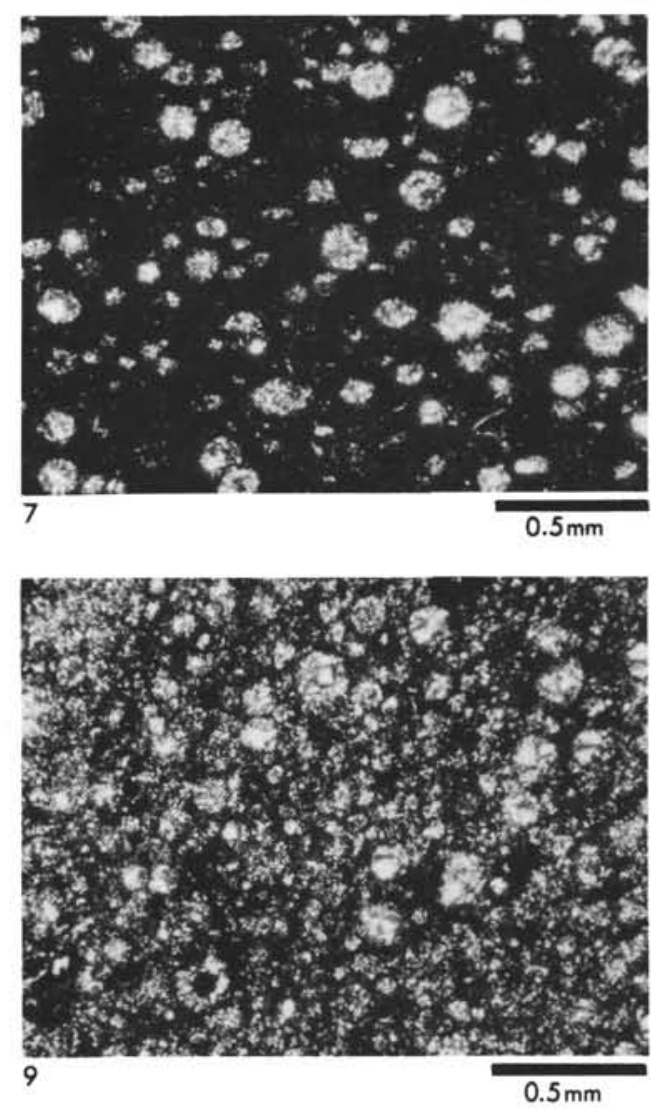


\section{PLATE 28}

Site 307

Figure 1

Figure 2

Figure 3

Figure 4

Figure 5

Figure 6
7-1 (158 m: Hauterivian/Valanginian). Calcareous porcellanite containing ripple-like sedimentary structures.

7-1. Radiograph of Figure 1. The light areas are more silicified and have sharp basal contacts.

7-1. Photomicrograph of Figure 1 showing truncation of a silicified layer by an overlying one. Light area contains fine-grained chalcedony and minor carbonate; dark area is micritic carbonate and clay. Radiolarians and foraminifera are present. Polarized light.

7-1. Crossed nicols. Area impregnated and replaced by chalcedony has low interference colors.

9-1 (233 m: Valanginian). Photomicrograph of dolomitic porcellanite. Euhedral dolomite rhombs in fine-grained chalcedony. Polarized light.

9-1. Crossed nicols. 
PLATE 28
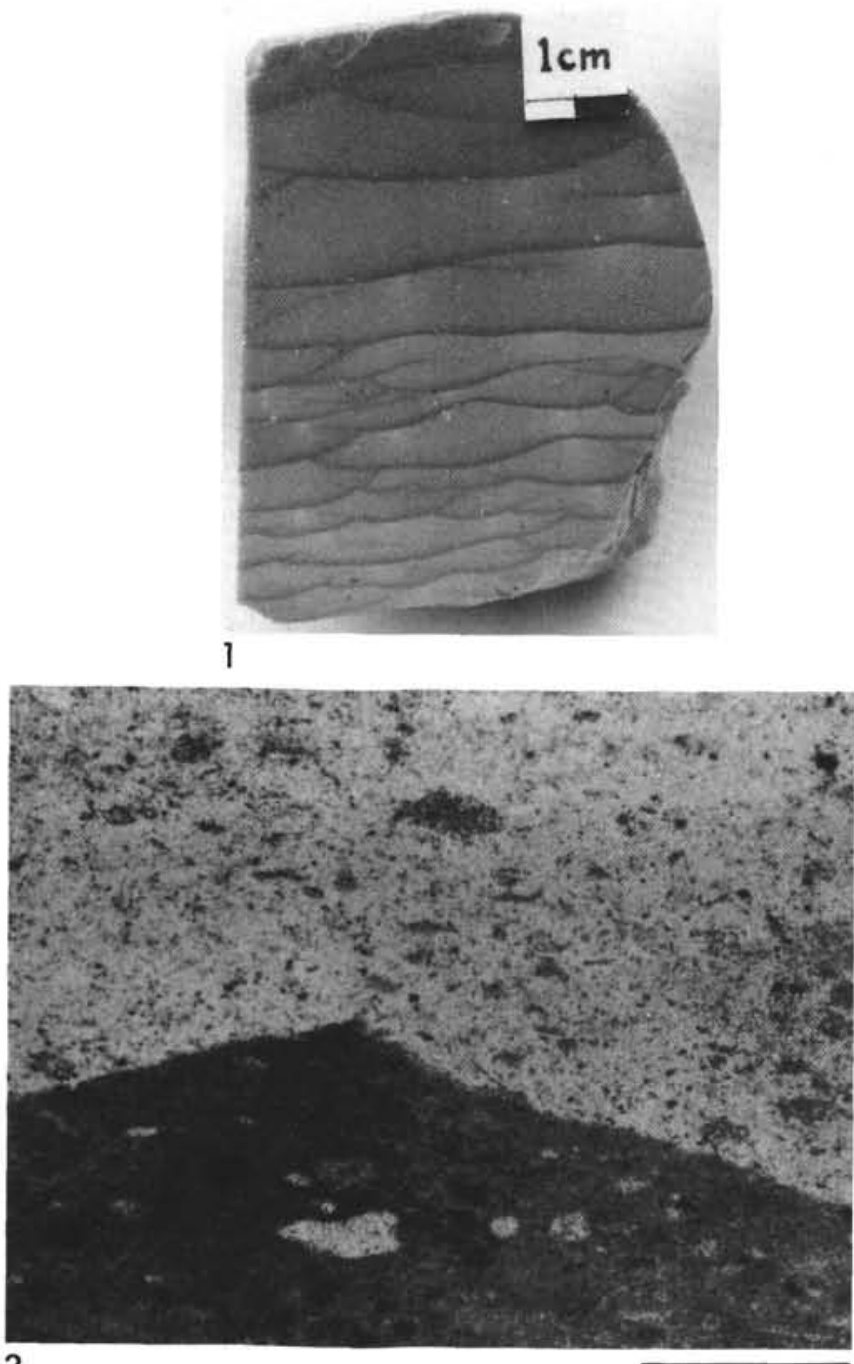

$0.5 \mathrm{~mm}$
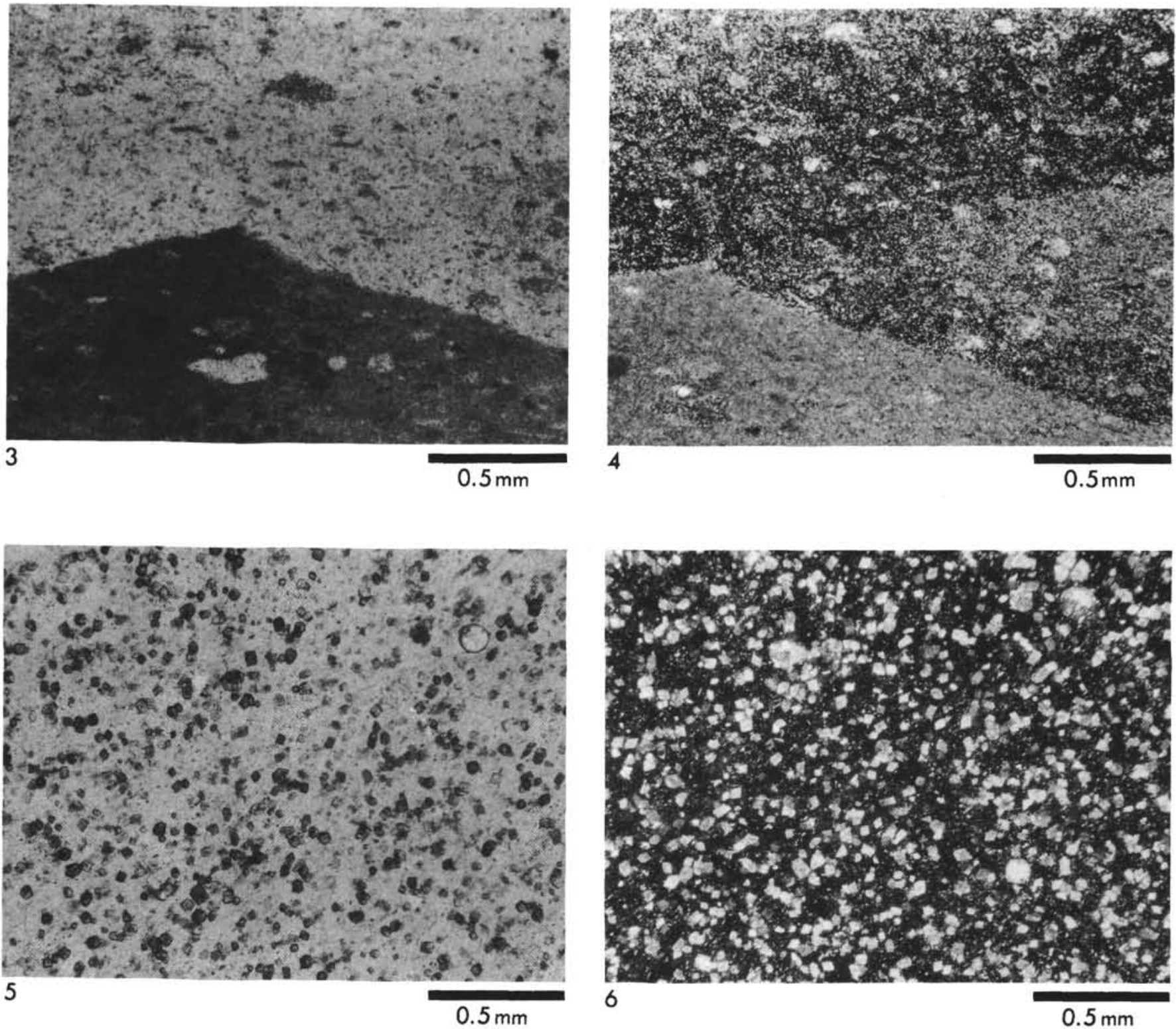
PLATE 29

Site 307

Figure 1 11, CC (298 m: Valanginian/Berriasian). Fractured chert cemented by megaquartz. Drusy quartz lines vugs.

Figure 2 11-1. Photomicrograph of radiolarian in dolomitic porcellanite. Lower part of test is filled with fine-grained chalcedony and remnants of opal-CT and represents a geopetal feature. Sheaves of chalcedony fill remaining test lumen. Test itself is replaced by chalcedony not in optical continuity with internal mold. Crossed nicols.

Figure 3 11, CC. Photomicrograph of Figure 1. Angular fragments of chert cemented by megaquartz. Polarized light.

Figure $4 \quad 11$, CC. Crossed nicols.

Figure 5 11, CC. Photomicrograph showing a general view of typical fine-grained chert. Polarized light.

Figure 6 11, CC. Crossed nicols. Chert with pinpoint extinction. 
PLATE 29
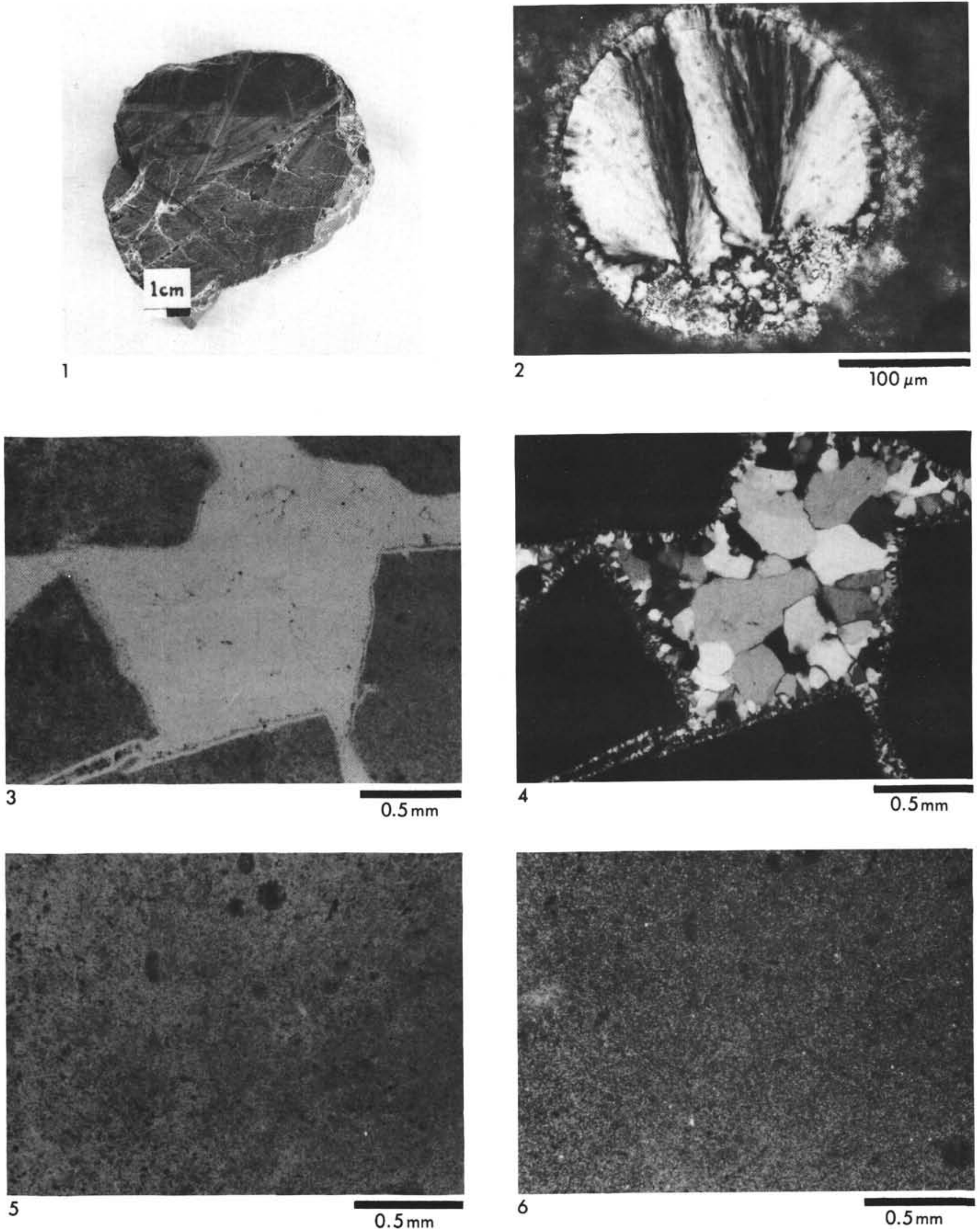